\title{
EFEITO DE DIFERENTES NÍVEIS INICIAIS DE IMUNOGLOBULINAS ADQUIRIDAS DO COLOSTRO SOBRE A FLUTUAÇÃO DE PROTEÍNAS SÉRICAS E DESEMPENHO DE BEZERRAS DA RAÇA HOLANDESA
}

PATRICIA PAULETTI

Engenheiro Agrônomo

Orientador: Prof. Dr. RAUL MACHADO NETO

Dissertação apresentada à Escola Superior de Agricultura "Luiz de Queiroz", Universidade de São Paulo, para obtenção do título de Mestre em Agronomia, Área de Concentração: Ciência Animal e Pastagens.

PIRACICABA

Estado de São Paulo - Brasil

Julho - 1999 
Dados Internacionais de Catalogação na Publicação (CIP)

DIVISÃo DE BIBLIOTECA E DOCUMENTAÇÃO - Campus "Luiz de Queiroz"/USP

Pauletti, Patricia

Efeito de diferentes niveis iniciais de imunoglobulinas adquiridas do colostro sobre a flutuação de proteinas séricas e desempenho de bezerras da raça Holandesa / Patricia Pauletti. - Piracicaba, 1999.

$104 \mathrm{p}$.

Dissertação (mestrado) - - Escola Superior de Agricultura Luiz de Queiroz, 1999. Bibliografia.

1. Bezerra holandesa 2. Colostro 3. Desempenho animal 4. Imunoglobulina 5. Proteina sérica l. Título

CDD 636.234

"Permitida a copia total ou parcial deste documento, desde que citada a fonte. O Antor" 
A

meus pais, Osmar e Laura pelo

exemplo e apoio constantes

Ao querido Gérsio por toda sua

paciência e colaboração

DEDICO. 


\section{AGRADECIMENTOS}

Ao Prof. Dr. Raul Machado Neto por seu exemplo, dedicação e incentivo constantes, essenciais a minha formação acadêmica e profissional;

Ao Prof. Dr. Irineu Umberto Packer, pela dedicada ajuda na realização das análises estatísticas;

Ao Prof. Dr. Raul Dantas d'Arce, pela colaboração e apoio recebidos;

Ao Prof. Dr. Mário Massayuki Inomoto, pela leitura e correção do original;

Ao Engenheiro Agrônomo William Tabchouri e Sr. João Roberto M. Lembi pelo consentimento e facilidades colocadas a disposição, permitindo a realização de parte do trabalho na Fazenda Tainá;

Ao CNPq pela ajuda finaceira destinada a este trabalho;

A querida amiga Rosana pela paciência, colaboração e amizade presentes em todos os momentos;

Aos estagiários do Laboratório de Anatomia e Fisiologia Animal Gláucio, Daniel e Laerte, pela colaboração constante e amizade que facilitaram a realização deste trabalho;

Aos funcionários do Departamento de Zoologia, pelo carinho e amizade;

$E$ finalmente, a todos aqueles que direta ou indiretamente deram sua contribuição, permitindo a realização deste trabalho. 


\section{SUMÁRIO}

Página

LISTA DE FIGURAS

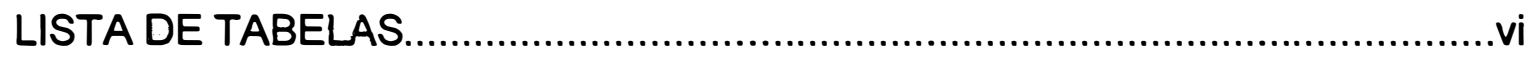

LISTA DE APENDICES ..........................................................................

RESUMO

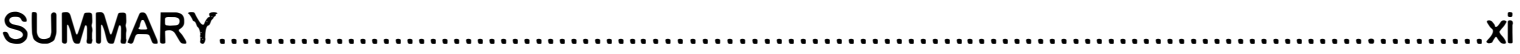

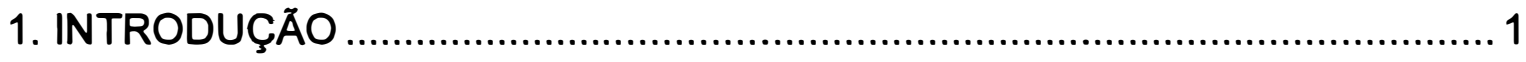

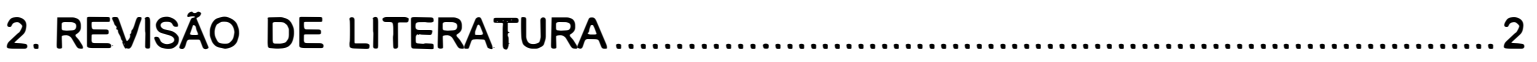

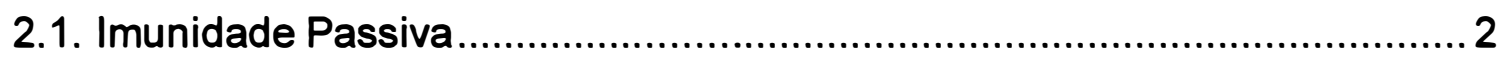

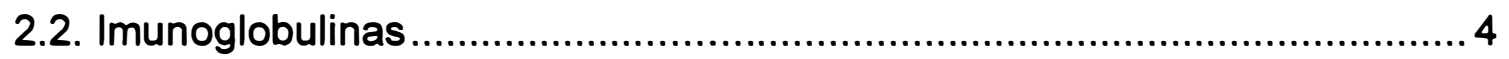

2.3. Colostro - Produção e Importância ………………………………......

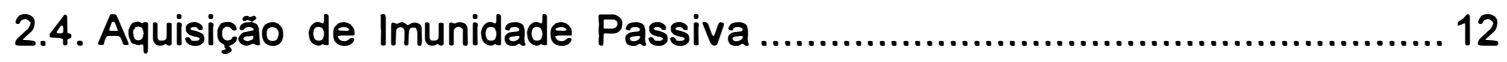

2.4.1. Absorção de Imunoglobulinas ...................................................... 12

2.4.2. Fatores que Influem no Processo de Absorção ……………….... 15

2.5. Transição da Imunidade Passiva para Ativa e Desempenho............. 22

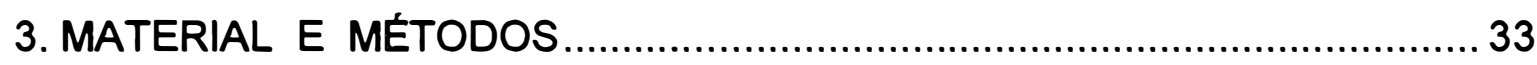

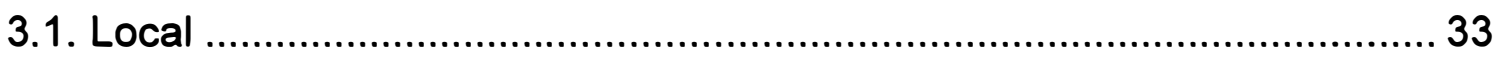

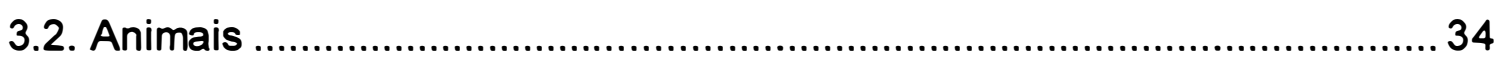

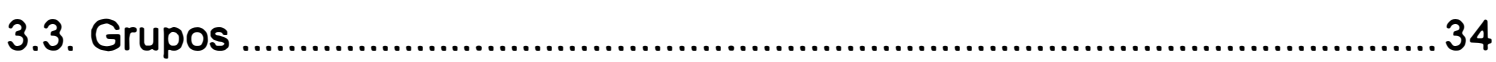

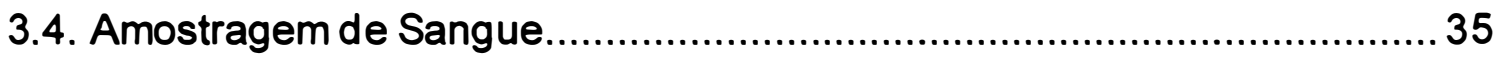

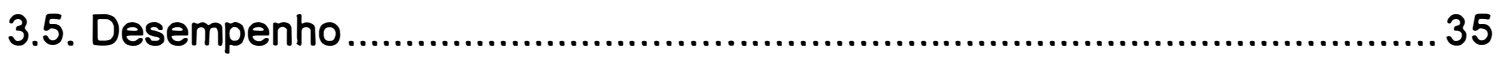

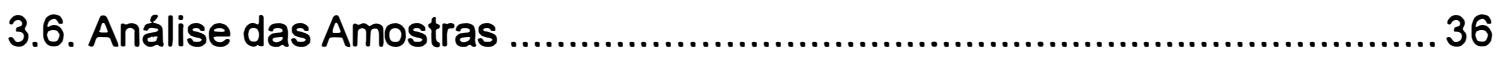

3.7. Delineamento Experimental e Análise Estatística................................. 37

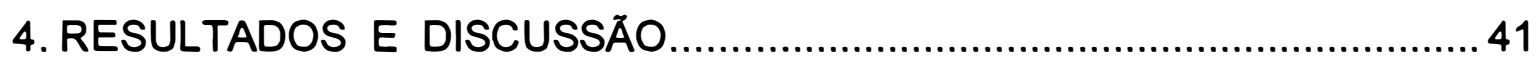

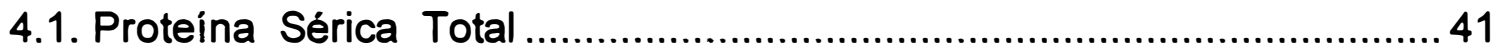

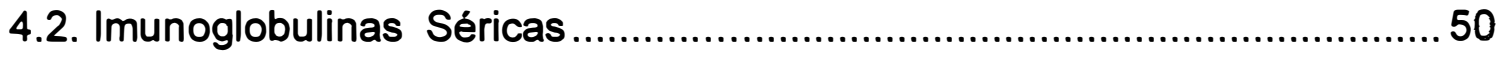

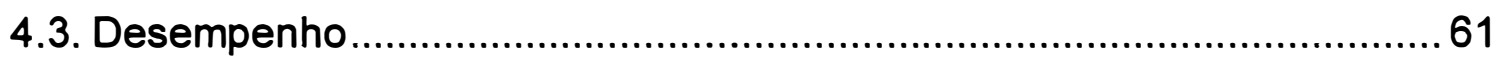

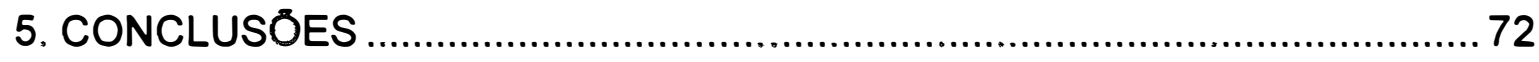

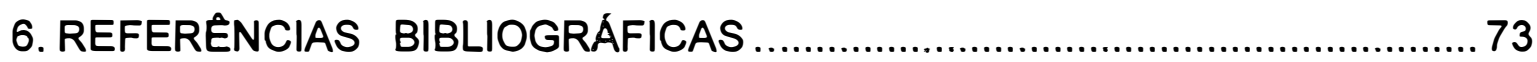




\section{LISTA DE FIGURAS}

Página

Figura 1. Flutuação da concentração média de proteína total sérica $(\mathrm{g} / 100 \mathrm{~mL})$ nos grupos experimentais.

Figura 2. Flutuação da concentração média de proteína total $(\mathrm{g} / 100 \mathrm{~mL}) \mathrm{com}$ valores ajustados.

Figura 3. Flutuação da concentração média de lgG sérica $(\mathrm{mg} / \mathrm{mL})$ nos grupos experimentais.

Figura 4. Flutuação da concentração média de lgG sérica $(\mathrm{mg} / \mathrm{mL})$ com valores ajustados.

Figura 5. Pesos médios observados nos grupos experimentais no período de 1 a 60 dias de idade.

Figura 6. Consumo médio de concentrado ( $g$ ) nos diferentes grupos experimentais.

Figura 7. Flutuação da concentração média de $\lg G$ sérica $(\mathrm{mg} / \mathrm{mL})$ nos grupos separados de acordo com peso vivo inicial 


\section{LISTA DE TABELAS}

Página

Tabela 1. Período de transmissão de imunidade passiva em mamíferos. 3

Tabela 2. Concentração das diferentes imunoglobulinas (Ig) presentes nas secreções externas e soro de um bovino adulto.

Tabela 3. Classificação dos animais de acordo com a concentração inicial de imunoglobulinas séricas.

Tabela 4. Valores iniciais dos parâmetros referentes a variável PT 40

Tabela 5. Valores iniciais dos parâmetros referentes a variável lgG. 40

Tabela 6. Concentração média de proteína total sérica $(\mathrm{g} / 100 \mathrm{~mL})$ nos grupos experimentais.

Tabela 7. Concentração de PT sérica $(\mathrm{g} / 100 \mathrm{~mL})$ desconsiderando-se o valor de IgG inicial $(\mathrm{g} / 100 \mathrm{~mL})$. 46

Tabela 8. Valores médios preditos da concentração de proteína total sérica $(\mathrm{g} / 100 \mathrm{~mL})$ nos grupos experimentais. 48

Tabela 9. Concentração média de lgG sérica $(\mathrm{mg} / \mathrm{mL})$ nos grupos experimentais. 51

Tabela 10. Valores médios preditos da concentração de imunoglobulinas $(\mathrm{mg} / \mathrm{mL})$ nos grupos experimentais. 57

Tabela 11. Variações nas concentrações séricas de $\lg G(\mathrm{mg} / \mathrm{mL})$ nos grupos experimentais. 60

Tabela 12. Pesos médios $(\mathrm{kg})$ por grupo, no período de 1 a 60 dias de idade. 62

Tabela 13. Ganho de peso médio $(\mathrm{kg})$ dos grupos entre os períodos experimentais. 65 
Tabela 14. Consumo médio de concentrado (g) por grupo, no período de 1 a 60

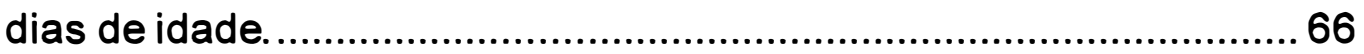

Tabela 15. Separação dos animais em três grupos conforme o peso vivo ao

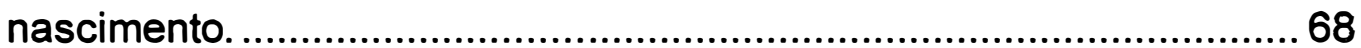

Tabela 16. Concentração média de lgG sérica $(\mathrm{mg} / \mathrm{mL})$ nos três grupos

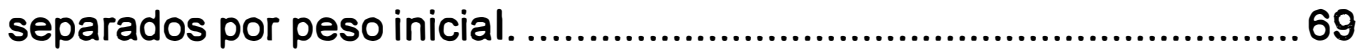




\section{LISTA DE APÊNDICES}

Página

Apêndice 1. Composição e níveis de garantia do concentrado usado na Fazenda Tainá. 87

Apêndice 2. Composição e niveis de garantia do concentrado usado no Departamento de Produção Animal - ESALQ/USP. 88

Apêndice 3. Concentração de proteína total sérica $(\mathrm{g} / 100 \mathrm{~mL})$ nas 26 unidades experimentais do grupo 1 (grupo baixo), até 60 dias de idade. 89

Apêndice 4. Concentração de proteína total sérica $(\mathrm{g} / 100 \mathrm{~mL})$ nas 15 unidades experimentais do grupo 2 (grupo médio), até 60 dias de idade. .....90

Apêndice 5. Concentração de proteína total sérica $(\mathrm{g} / 100 \mathrm{~mL})$ nas 18 unidades experimentais do grupo 3 (grupo alto), até 60 dias de idade.

Apêndice 6. Concentração de imunoglobulina sérica $(\mathrm{mg} / \mathrm{mL})$ nas 26 unidades experimentais pertencentes ao grupo 1 (grupo baixo), até 60 dias de idade. 92

Apêndice 7. Concentração de imunoglobulina sérica $(\mathrm{mg} / \mathrm{mL})$ nas 15 unidades experimentais pertencentes ao grupo 2 (grupo médio), até 60 dias de idade. .93

Apêndice 8. Concentração de imunoglobulina sérica $(\mathrm{mg} / \mathrm{mL})$ nas 18 unidades experimentais pertencentes ao grupo 3 (grupo alto), até 60 dias de idade. .94

Apêndice 9. Peso dos animais $(\mathrm{kg})$ nas 26 unidades experimentais do grupo 1 (grupo baixo), até 60 dias de idade. 95

Apêndice 10. Peso dos animais $(\mathrm{kg})$ nas 15 unidades experimentais do grupo 2 (grupo médio), até 60 dias de idade. 96 
Apêndice 11. Peso dos animais $(\mathrm{kg})$ nas 18 unidades experimentais do grupo 3 (grupo alto), até 60 dias de idade.

Apêndice 12. Consumo de concentrado (g) nas 26 unidades experimentais do grupo 1 (grupo baixo), até 60 dias de idade. 98

Apêndice 13. Consumo de concentrado $(\mathrm{g})$ nas 15 unidades experimentais do grupo 2 (grupo médio), até 60 dias de idade. 99

Apêndice 14. Consumo de concentrado $(\mathrm{g})$ nas 18 unidades experimentais do grupo 3 (grupo alto), até 60 dias de idade. 100

Apêndice 15. Consumo de feno $(\mathrm{g})$ dos animais pertencentes ao Departamento de Produção Animal - ESALQ/USP 101

Apêndice 16. Ganho de peso médio total $(\mathrm{kg})$ dos animais nos diferentes grupos experimentais. 102

Apêndice 17. Probabilidades encontradas na comparação entre os grupos durante o período experimental em relação a concentração média de PT $(\mathrm{g} / 100 \mathrm{~mL})$. 103

Apêndice 18. Probabilidades encontradas na comparação entre os grupos durante o período experimental em relação a concentração média de $\lg G(\mathrm{mg} / \mathrm{mL})$. 103

Apêndice 19. Probabilidades encontradas na comparação entre os grupos durante o período experimental em relação ao ganho de peso médio (kg). 104

Apêndice 20. Probabilidades encontradas na comparação entre os grupos durante o período experimental em relação ao consumo médio de concentrado $(\mathrm{g})$. 104 


\section{EFEITO DE DIFERENTES NIVEIS INICIAIS DE IMUNOGLOBULINAS ADQUIRIDAS DO COLOSTRO SOBRE A FLUTUAÇĀO DE PROTEÍNAS SÉRICAS E DESEMPENHO DE BEZERRAS DA RAÇA HOLANDESA}

Autora: Patricia Pauletti

Orientador: Prof. Dr. Raul Machado Neto

\section{RESUMO}

O comportamento imunológico e desempenho foram avaliados em 59 bezerras da raça Holandesa do nascimento até 60 dias de idade. Os animais foram separados de acordo com a concentração inicial de imunoglobulinas séricas adquiridas passivamente e alocados nos seguintes grupos: Grupo 1: animais com baixo nível de imunidade passiva (até $20 \mathrm{mg} / \mathrm{mL}$ de $\mathrm{lgG}$ ); Grupo 2: animais com nível médio de imunidade passiva (entre 20 a $30 \mathrm{mg} / \mathrm{mL}$ de $\lg G$ ) e Grupo 3: animais com alto nível de imunidade passiva (acima de $30 \mathrm{mg} / \mathrm{mL}$ de $\mathrm{lg} \mathrm{G}$ ). As variáveis séricas analisadas foram proteína total e imunoglobulina $G$ (lgG) e as variáveis relacionadas a desempenho foram peso, ganho de peso e consumo de concentrado inicial. Nas análises séricas foram utilizados os métodos do biureto para quantificação da proteína total e imunodifusão radial para quantificação da imunoglobulina $G$. O delineamento experimental utilizado foi inteiramente casualizado em parcelas subdivididas no tempo, sendo o efeito do nível inicial de imunoglobulinas aplicado às parcelas $e$ as medidas repetidas no tempo consideradas como subparcelas. Pela pronunciada amplitude de variação quanto a aquisição de anticorpos passivos observada entre os grupos experimentais (7,7 mg $\mathrm{lg} / \mathrm{mL}$ a $39 \mathrm{mg} \mathrm{lgG} / \mathrm{mL}$ às 24 horas), determinou-se que o desempenho animal até 60 dias de idade não foi influenciado pela estimulação da síntese endógena de anticorpos estabelecida precocemente nos animais do grupo baixo e sequer pelo prolongado período de catabolismo dos anticorpos adquiridos passivamente observado nos animais dos grupos alto e médio. 
EFFECT OF DIFFERENT INITIAL LEVELS OF PASSIVE IMMUNOGLOBULINS ON THE BEHAVIOR OF SERUM PROTEINS AND CALVES PERFORMANCE

Author: Patricia Pauletti Adviser: Prof. Dr. Raul Machado Neto

\section{SUMMARY}

The immunological status and performance were evaluated in fiftynine female Holstein calves. The experimental period comprised the first sixty days of live. The animals were separed in three groups according to the initial level of passive immunity and allocated to the groups described as follows: Group 1: animals with low levels of passive immunity (bellow $20 \mathrm{mg} \mathrm{lgG} / \mathrm{mL}$ ); Group 2: animals with medium levels of passive immunity (between 20 and $30 \mathrm{mg} \mathrm{ggG} / \mathrm{mL}$ ) and Group 3: animals with high levels of passive immunity (above $30 \mathrm{mg} \mathrm{ggG} / \mathrm{mL}$ ). The blood parameters analysed were total serum protein and serum immunoglobulin $G(\lg G)$ and the variables related to performance were body weight, body weight gain and calf starter consumption. Blood parameters were assayed by biuret method and radial immunodifusion. Data were analysed as a randomized split-plot statistical model. Despite the great variation of the initial passive immunity in the experimental groups, the calves peformance in the first 60 days of life was not affected either by the mechanisms of catabolism (high and medium groups) or the early anabolism (low group) verified in the animals. 


\section{INTRODUÇÃO}

A imunidade adquirida pelos animais recém-nascidos é denominada passiva $e$, no caso dos ruminantes, o feto não adquire imunoglobulinas maternas no útero devido ao tipo de placenta. Portanto, nesses animais, a aquisição de imunidade passiva pelo neonato depende da ingestão e absorção de quantidades adequadas de imunoglobulinas do colostro, dentro das primeiras 24 horas de vida. Esses anticorpos adquiridos passivamente possuem curto período de atividade, algumas semanas, sendo porém, de vital importância no periodo de capacitação do animal para produção endógena. Uma falha na absorção é crítica para a subsequente resistência a doenças pelos animais.

Embora a necessidade de ingestão de colostro esteja há muito tempo estabelecida, pouco se conhece sobre a relação sistema imune desempenho. Há evidências que o impacto da ativação do sistema imune em animais com niveis baixos de imunidade passiva possa trazer mudanças no metabolismo, causando prejuizos ao desempenho nos estágios iniciais de crescimento, o que traria consequências indesejáveis em estágios futuros de desenvolvimento.

O presente trabalho teve por objetivo estudar o efeito de niveis iniciais de proteção passiva adquirida, bem como a precocidade e intensidade do estabelecimento da proteção ativa em relação ao desempenho animal. 


\section{REVISÃO DE LITERATURA}

\subsection{Imunidade Passiva}

O mamífero recém-nascido poderia ser rapidamente tomado por microrganismos invasivos antes que tivesse tempo de produzir anticorpos para combatê-los, não fosse pelas imunoglobulinas (Ig) recebidas da mãe. Os anticorpos produzidos pela mãe e presentes na circulação materna são transmitidos para o feto ou neonato e atingem concentrações em seu soro aproximadamente equivalentes a encontradas no animal adulto (Brambell 1958; Jeffcott, 1972; Porter, 1979). Portanto, o recém-nascido depende, no início de sua vida, da imunidade recebida da mãe, a qual é chamada de imunidade passiva.

Em algumas espécies, as imunoglobulinas são obtidas pelo feto antes do nascimento através da placenta (Argenzio, 1984). Por sua vez, os ruminantes, equinos e suínos, nascem sem anticorpos ou somente com traços em sua circulação, sendo as imunoglobulinas obtidas após o nascimento, através do colostro (Brambell, 1958). Os períodos em que ocorre a transmissão de imunidade passiva em alguns mamíferos podem ser observados na Tabela 1. 
Tabela 1. Período de transmissão de imunidade passiva em mamíferos.

\begin{tabular}{lcc}
\hline & \multicolumn{2}{c}{ Transmissão de Imunidade Passiva } \\
\cline { 2 - 3 } Espécie & Pré-Natal & Pós-Natal \\
\hline Cavalo & 0 & $+++(24$ horas $)$ \\
Porco & 0 & $+++(24-36$ horas $)$ \\
Boi, cabra, carneiro & 0 & $+++(24$ horas $)$ \\
Canguru & 0 & $+++(180$ dias $)$ \\
Cão, gato & + & $++(1-2$ dias $)$ \\
Galinha & ++ & $++(<5$ dias $)$ \\
Porco-espinho & + & $++(40$ dias $)$ \\
Camundongo & + & $++(16$ dias $)$ \\
Rato & + & $++(20$ dias $)$ \\
Cobaia & +++ & 0 \\
Coelho & +++ & 0 \\
Homem, macaco & +++ & 0 \\
\hline
\end{tabular}

0 = nenhuma absorção ou transferência.

+ até $+++=$ graus de absorção ou transferência.

Fonte: Brambell, (1958).

O feto do ruminante é particularmente suscetível a agentes infecciosos por três razões principais: (1) a placenta do ruminante não permite a transferência das imunoglobulinas maternas durante a gestação para a proteção inicial; (2) o sistema imune fetal não tem experiência e portanto pode não ser eficientemente funcional; (3) ० ambiente fetal produz fatores ou células que contribuem para a multiplicação de microrganismos (Perino \& Rupp, 1994). Segundo Nocek et al. (1984), os ruminantes nascem com menos de $10 \%$ da imunidade necessária para proteção contra os agentes infecciosos aos quais, normalmente, são expostos nas primeiras semanas de vida.

Quando se verificam altas concentrações de imunoglobulinas em bezerros recém-nascidos, provavelmente, elas originam-se de estimulação 
antigênica durante a vida fetal ou foram transferidas passivamente através da placenta que tenha sofrido alguma injúria durante a gestação (Kruse, 1983).

Considerando os diversos tipos de placenta, há uma correlação entre características de sua estrutura anatômica e permeabilidade aos anticorpos. Assim, a permeabilidade da placenta é inversamente proporcional ao número de camadas de tecidos interpostas entre a circulação materna e a fetal. Pode-se distinguir quatro tipos de placenta: epiteliocorial, sindesmocorial, endoteliocorial e haemocorial, se tecidos maternais, epitélio uterino, tecido conjuntivo e endotélio vascular todos persistirem ou desaparecerem nesta ordem. A placenta sindesmocorial, presente em ruminantes, impede a passagem de anticorpos da circulação materna para a fetal, fazendo com que os bezerros nasçam com niveis insignificantes de imunoglobulinas no soro (McCoy et al., 1970; Simpson \& Smeaton, 1972; Porter, 1976; Tizard, 1985).

\subsection{Imunoglobulinas}

As imunoglobulinas no sangue, linfa e secreções externas formam uma família de proteinas que são notáveis por sua heterogeneidade no que diz respeito à estrutura química.

As imunoglobulinas são glicoproteinas globulares apresentando um modelo básico constituído de duas cadeias polipeptídicas leves e duas cadeias pesadas, podendo ser encontradas na forma de monômero ou polímero. Tanto as cadeias leves quanto as pesadas estão interligadas por pontes dissulfídicas (Porter, 1975; Ferri et al., 1979).

As cinco maiores classes de imunoglobulinas ( $\lg G, \lg M, \lg A, \lg D$ e $\lg \mathrm{E})$, as quais constituem o principal componente do sistema imunológico humoral, diferem entre si na estrutura (sequência de aminoácidos) das cadeias 
pesadas, sendo que as cadeias leves são iguais para todas as classes de imunoglobulinas. As classes diferem, também, em função e distribuição relativa na circulação. Além das cinco classes, são identificadas subclasses de lgG e IgA, diferenciadas através de aspectos estruturais e antigênicos.

Cada molécula de IgG é constituída de uma unidade de quatro cadeias, possuindo dois sítios de combinação especificos para o determinante antigênico que induziu sua sintese. Em todas as espécies de animais domésticos, a lgG é a imunoglobulina com maior concentração no plasma, entre 65 e $80 \%$ do total de imunoglobulinas encontradas. Age principalmente contra antígenos solúveis, neutralizando toxinas provenientes de bactérias e fornece imunidade antibacteriana e antiviral (Avrech et al., 1994). Em ruminantes é a principal imunoglobulina presente no colostro, sendo essencial na defesa contra infecções durante as primeiras semanas de vida (Butler, 1969).

A IgG não é sintetizada na glândula mamária, mas sim transferida seletivamente da circulação sanguínea materna para o colostro. A imunização passiva através da lgG materna define o status imunológico do recém-nascido, atuando no desenvolvimento da imunidade ativa. As IgG adquiridas passivamente pelo colostro, além de conferirem proteção ao recém-nascido, modulam a resposta imune, através de mecanismos que inibem o crescimento precoce de células produtoras de anticorpos (Porter, 1979). Essa situação também foi verificada por Machado Neto \& Packer (1986).

A IgM encontra-se principalmente sob a forma de pentâmero. Essa imunoglobulina é um agente aglutinante e inicia a primeira linha de defesa contra a invasão de agentes bacterianos. Cada molécula de $\lg M$ possui dez sítios de ligação ao antígeno podendo combinar-se com dez determinantes antigênicos conferindo, assim, maior eficácia que uma molécula de lgG (Tizard, 
1985). Porém, em bovinos, esse grupo representa menos de $5 \%$ das imunoglobulinas encontradas no soro e no colostro. Ao contrário de $\lg G$, a $\lg M$ estimula o desenvolvimento de células produtoras de anticorpos (Porter, 1975).

A IgA é encontrada em duas formas, uma delas contém uma peça secretora conferindo proteção imunológica para a superficie das mucosas. A outra forma, encontrada no sistema circulatório, pode agir contra a invasão de agentes infecciosos (Avrech et al., 1994).

A forma dimérica de IgA é caracteristicamente composta de duas unidades de quatro cadeias ligadas por uma peça secretora, sintetizada por células epiteliais. Essa peça secretora é provavelmente responsável pelo transporte ativo de $\lg A$ através das células epiteliais. Esse mecanismo de transporte único para IgA justifica sua predominância nas secreções. Pesquisas desenvolvidas em várias espécies animais têm mostrado que a maior resposta por anticorpos no intestino é mediada pela classe de imunoglobulinas $A$, a qual não produz resposta inflamatória. Em adição, $\lg A$ é resistente a proteólise, o que é uma vantagem nas secreções do trato intestinal. Esse anticorpo age prevenindo $o$ ataque e a penetração dos antígenos e microrganismos no epitélio intestinal, retendo-os na mucosa, onde sofrerão degradação pelas enzimas proteolíticas e antibacterianas. Previne, também, a estimulação de outras armas ativas do sistema imune (Newby et al., 1988).

A IgE representa aproximadamente $0,005 \%$ da imunoglobulina total presente nos animais e, como lgG, consiste de somente uma unidade de quatro cadeias. É a imunoglobulina responsável, principalmente, por mediar respostas de hipersensibilidade, ligada aos mastócitos na lâmina própria pode induzir, pelo contato com o antígeno, a liberação de aminas vaso ativas (Bourne \& Newby, 1981; Ferri et al., 1979). 


\subsection{Colostro - Produção e Importância}

O colostro é a primeira secreção láctea produzida após o parto e, nos bovinos, consiste da mistura de secreções da glândula mamária e de elementos do soro sanguíneo, principalmente imunoglobulinas e outras proteínas séricas, que são acumuladas durante o período pré-parto (Foley \& Otterby, 1978).

A quase totalidade das imunoglobulinas presentes no colostro são derivadas diretamente do sangue e transportadas ativamente através do epitélio alveolar em preferência à síntese na glândula mamária (Dixon et al., 1961; Jeffcott, 1972). Esse mecanismo é altamente seletivo em bovinos e a $\lg _{1}$ perfaz $86 \%$ do total de imunoglobulinas presentes no colostro, sendo que a IgM, a $\lg A$ e a $\lg G_{2}$ estão presentes em concentrações consideravelmente menores (Sasaki et al., 1976; Roy, 1990; Perino \& Rupp, 1994). Na Tabela 2 é mostrada a concentração das diferentes imunoglobulinas presentes nas secreções externas e soro de um bovino adulto.

Durante a gestação de vacas leiteiras há uma mobilização de lgG sérica para a glândula mamária, resultando em uma concentração de imunoglobulinas no colostro cinco a dez vezes maior que a concentração sérica materna, mecanismo esse que ocasiona uma queda da concentração sérica de anticorpos (Larson \& Kendall, 1957; Perino \& Rupp, 1994). Dixon et al. (1961), Brandon \& Lascelles (1971) e Foley \& Otterby (1978) afirmaram que, durante as três últimas semanas pré-parto, 500 a 700 gramas de imunoglobulinas são transferidas para a glândula mamária. 
Tabela 2. Concentração das diferentes imunoglobulinas (lg) presentes nas secreções externas e soro de um bovino adulto.

\begin{tabular}{lcccc}
\hline & \multicolumn{4}{c}{ Concentração das Imunoglobulinas (mg/L) } \\
\cline { 2 - 5 } & $\lg \mathrm{A}$ & $\lg \mathrm{G}_{1}$ & $\operatorname{lgG}_{2}$ & $\operatorname{lgM}$ \\
\hline secreção lacrimal & 2600 & 300 & 120 & 6 \\
secreção nasal & 1950 & 40 & 25 & - \\
saliva & 560 & 30 & 10 & 10 \\
fluido espermático & 130 & 130 & 110 & - \\
secreção gastrointestinal & 240 & 250 & 60 & - \\
bile & 80 & 100 & 90 & 50 \\
urina & 0.7 & 0.8 & 1 & - \\
colostro & 4400 & 75000 & 1900 & 4900 \\
leite & 50 & 350 & 60 & 40 \\
soro & 300 & 10500 & 7900 & 2500 \\
\hline
\end{tabular}

Fonte: Roy, (1990).

O mecanismo seletivo pelo qual ocorre a transferência das imunoglobulinas do sangue para a glândula mamária envolve um conjunto de fatores. Sobre 0 mecanismo de transporte seletivo para $\operatorname{lgG}_{1}$, sabe-se que receptores específicos, localizados na membrana basal ou intercelular da célula acinar epitelial, ligam-se à $\lg _{1}$, havendo invaginação da membrana celular e formação de vesículas que a transportam para o lúmen dos alvéolos, liberandoa por exocitose (Watson, 1980). Essa transferência sofre, também, controle hormonal com a participação de estrogênios e progestogênios atuando na sintese e transporte das imunoglobulinas para a glândula mamária (Smith et al., 1971).

A concentração de imunoglobulinas no colostro é alta no momento do parto e decresce a cada aleitamento sucessivo no período pós-parto. A concentração média de imunoglobulinas em vacas Holandesas começa a 
diminuir entre o primeiro colostro e 12 e 24 horas após o parto, mas apesar da diminuição, a IgG continua sendo a principal imunoglobulina durante toda a lactação (Oyeniyi \& Hunter, 1978; Muller \& Ellinger, 1981; Stott et al., 1981; Newby et al., 1982; Lucci, 1989).

Segundo Kruse (1970), o conteúdo de Ig no colostro declina rapidamente, sendo que 16 horas após o parto a redução chega a $40 \%$. Michanek et al. (1989), além de terem encontrado resultados semelhantes, concluíram que bezerros recém-nascidos, ao ingerirem o colostro de $2^{\text {a }}$ ou $3^{\text {a }}$ ordenhas, provavelmente estarão ingerindo um colostro com baixas concentrações de lg.

Os animais que falham em absorver os anticorpos derivados da mãe são na maioria hipogamaglobulinêmicos, tornando-se mais suscetiveis a doenças neonatais com consequentes prejuizos ao desempenho animal e elevados índices de mortalidade (Gay et al., 1965; Boyd, 1972; Husband et al., 1972; Edwards et al., 1982; Besser et al., 1985; Gay, 1994; Wittum \& Perino, 1995; Ramin et al., 1996). De maneira geral, os autores concordam que a resistência dos animais à alta incidência de doenças infecciosas neonatais, principalmente septicemia, diarréia e doenças respiratórias, depende da ingestão de níveis adequados de lg do colostro.

O estudo dessa relação não é fato recente. Já em 1922 Smith \& Litlle observaram que 75 a $80 \%$ dos animais recém-nascidos morriam quando privados de colostro. Selman et al. (1971) e Penhale et al. (1973) encontraram relação entre mortalidade de animais jovens e baixa concentração de anticorpos séricos derivados do colostro. McGuire et al. (1976) observaram em seu estudo que animais doentes que morreram entre dois e sete dias de idade não absorveram quantidades adequadas de anticorpos passivos e aqueles que 
morreram entre oito e 23 dias de idade apresentavam baixa concentração sérica de imunoglobulinas.

Ribeiro et al. (1983) verificaram que bezerros da raça Holandesa hipogamaglobulinêmicos apresentaram maiores taxas de morbidez e mortalidade em situações de estresse tanto fisiológico como do ambiente, comparadas àquelas apresentadas por animais com niveis normais de anticorpos, nas mesmas condições. De acordo com Stott et al. (1976), a imunidade passiva dos bezerros pode ser influenciada por fatores estressores como temperatura, umidade, dor, medo e apreensão devido a maior liberação de corticosteróides.

Nocek et al. (1984) observaram que bezerros privados de colostro tiveram maior índice de diarréia, maior taxa de mortalidade e ganho de peso mais lento no início da vida. Arthington (1997) relatou que animais com falha de transferência de imunidade passiva têm 6,4 mais chances de apresentar morbidez e 5,4 vezes mais chances de morrer do que animais que apresentavam niveis adequados.

Quando os animais recém-nascidos entram em contato com antígenos comuns aos bovinos, os mesmos são reconhecidos pelas imunoglobulinas derivadas do colostro materno, impedindo o reconhecimento e uma resposta imunológica ativa do animal. Ao contrário, antígenos não comuns aos bovinos são capazes de induzir uma resposta ativa nos bezerros recémnascidos com menos de uma semana de idade (Arthington, 1997).

Alguns trabalhos relatam a maior incidência de doenças neonatais com o uso de suplementos. Machado Neto et al. (1989), trabalhando com diferentes regimes de aleitamento, verificaram uma tendência dos animais alimentados com sucedâneo apresentarem diarréia mais cedo e com maior 
intensidade, afetando, consequentemente, o ganho de peso dos bezerros no período crítico de incidência da mesma. Essas observações podem estar relacionadas com o fato do sucedâneo não conter imunoglobulinas ativas, determinando assim uma proteção menos eficiente em nível de trato digestivo.

Resultado semelhante foi encontrado por Garry et al. (1996) e Mee et al. (1996), ambos comparando colostro e suplementos comerciais, constataram que bezerros alimentados com suplementos apresentam menores concentrações séricas de lgG e adoecem mais que aqueles que recebem colostro natural. Isso está relacionado ao fato das imunoglobulinas derivadas das vacas de um mesmo rebanho serem específicas para patógenos encontrados pelos bezerros no local de origem. Hopkins \& Quigley (1997) também não encontraram vantagens na administração de colostro associado a suplementos, e segundo os autores quando colostro de alta qualidade (altas concentrações de lgG) é oferecido ao animal nas primeiras horas de vida o uso de suplementos não traria benefícios ao animal.

Quigley et al. (1998), comparando suplementos comerciais e colostro materno, encontraram menores valores quanto a eficiência aparente de absorção em bezerros alimentados com suplementos comerciais. Os autores ressaltam que produtos comerciais contêm baixas porcentagens e proporções de lgG em relação aos sólidos totais, sendo que a massa de material protéico, que não lgG, poderia diminuir a absorção das imunoglobulinas pela competição com sítios de ligação no intestino.

A composição e as características físicas do colostro variam com um grande número de fatores, incluindo individualidade do animal, raça, número de parições, duração do período seco e tempo pós-parto. Os nutrientes, individualmente, são afetados diferentemente por esses fatores (Oyeniyi \& 
Hunter, 1978; Muller \& Ellinger, 1981; Donovan et al., 1986).

Tem sido demonstrado que a variação na qualidade do colostro está relacionada a falhas de transmissão de imunidade passiva. Fleenor \& Stott (1980), para o desenvolvimento do método que relaciona concentração de imunoglobulinas e gravidade específica do colostro; classificaram teores abaixo de $21,8 \mathrm{mg} / \mathrm{mL}$ como pobres e acima de $49,82 \mathrm{mg} / \mathrm{mL}$ como excelentes. Já para Nocek et al. (1984), concentrações de imunoglobulinas no colostro abaixo de 45 $\mathrm{mg} / \mathrm{mL}$ são consideradas baixas e acima de $60 \mathrm{mg} / \mathrm{mL}$, altas.

Vários estudos recomendam o fornecimento de pelo menos $5 \%$ do peso vivo animal em colostro nas primeiras cinco a seis horas de vida (Kruse, 1983; Donovan et al., 1986). Besser et al. (1991), estudando falha de transferência de imunidade passiva, recomendaram o fornecimento de $100 \mathrm{~g}$ de $\lg G_{1}$, independente da forma de aleitamento, para assegurar níveis adequados de imunoglobulinas séricas. Gay (1994), em estudo posterior, também recomendou o fornecimento de 100 gramas de imunoglobulinas na primeira refeição para se alcançar concentrações séricas que minimizem o risco de doenças e mortalidade neonatal. Em estudo recente, Arthington (1997) observou que a falha de transferência de imunidade passiva tende a aumentar quando são administrados colostros com concentrações de lg abaixo de 50 $\mathrm{mg} / \mathrm{mL}$ nas primeiras 24 horas de vida.

\subsection{Aquisição de Imunidade Passiva}

\subsubsection{Absorção de Imunoglobulinas}

Somente o intestino neonatal tem capacidade para a captação de grandes quantidades de proteína intacta. No mamífero adulto apenas 
quantidades relativamente pequenas e nutricionalmente insignificantes de proteinas podem ser absorvidas intactas (Argenzio, 1984).

A transferência das imunoglobulinas do colostro para os fluidos corporais do bezerro é resultado de um mecanismo de transporte passageiro e não seletivo através do epitélio absortivo do intestino delgado. Macromoléculas como IgG e IgM, que possuem peso molecular de 150000 e 1000000, respectivamente, são absorvidas intactas pelo mecanismo de pinocitose (Stott \& Menefee, 1978). A absorção é não seletiva para outras classes de lg, bem como para outras macromoléculas existentes no colostro, sendo as mesmas transferidas através do epitélio intestinal com aproximadamente igual eficiência.

De acordo com Stott et al. (1979b), todas as classes de imunoglobulinas mostram características comuns de absorção, seguida de rápida transferência intestinal durante as quatro horas após a primeira refeição de colostro. Klaus et al. (1969) e Husband et al. (1973) observaram que IgG e IgM são absorvidas pelo trato intestinal de bezerros recém-nascidos com a mesma eficiência. James et al. (1979), trabalhando com anticorpos marcados em bezerros, verificaram que o potencial de absorção de macromoléculas é distribuido variavelmente através do intestino delgado, com a porção distal apresentando maior absorção, ocorrendo principalmente nas células do jejuno e íleo.

Segundo Argenzio (1984), o intestino delgado neonato absorve macromoléculas através de um mecanismo endocítico. O primeiro estágio é a adsorção das macromoléculas pela membrana das microvilosidades da célula absortiva. No segundo estágio, quando essas macromoléculas atingem certa concentração crítica na borda das microvilosidades, ocorre a invaginação da membrana e formação de pequenas vesículas. O terceiro estágio é a migração 
das vesículas ligadas à membrana para a superfície basolateral da membrana celular; nessa região ocorre a exocitose, e as moléculas ganham o espaço intercelular. As moléculas de lg absorvidas entram na corrente sanguínea com a linfa via ducto torácico.

O processo de absorção de imunoglobulinas tem sido tema de estudo de várias pesquisas. Esse processo tem sido extensivamente estudado em ratos, porém em ruminantes as pesquisas não são conclusivas. Receptores têm sido associados ao processo de absorção de lgG em bezerros recémnascidos (Staley \& Bush, 1985; Besser \& Gay, 1994). Já em 1958 Brambell havia proposto a presença de receptores em animais recém-nascidos, sendo a proposta confirmada por Rodewald (1973) através de estudos ultra-estruturais em ratos lactentes, demonstrando que tanto a ligação como a internalização de imunoglobulinas $G$ ocorrem por um processo mediado por receptores. Os receptores estão envolvidos com seletividade e especificidade e protegeriam as imunoglobulinas contra a digestão proteolítica (Abrahamson \& Rodewald, 1980; Rodewald, 1980). A ligação lgG-receptor ocorre no pH das células do intestino (pH 6,0) e o complexo seria dissociado no espaço intercelular do meio interno onde o pH é 7,4 (Rodewald, 1976; Staley \& Bush, 1985).

Durante o período imediatamente pós-natal há um curto período em que a mucosa intestinal é altamente permeável a macromoléculas quando em contato com as mesmas, estimado entre 24 e 48 horas de vida nos animais ungulados (Brambell, 1958). A internalização aumentada de imunoglobulinas pelo intestino dura pouco tempo e, então, o intestino fecha-se para evitar posterior passagem de macromoléculas, incluindo patógenos, em grandes quantidades, que poderiam ser transportados através do epitélio intestinal para o sangue do recém-nascido (Lecce \& Morgan, 1962). 
Lecce (1973) propôs que o fechamento intestinal ocorre após o plasmalema das células do epitélio intestinal fazer contato com os nutrientes ingeridos e fluidos digestivos. Esse contato poderia estimular não especificamente as células, encerrando sua quantidade finita de pinocitose.

Vários fatores contribuem para a ocorrência de condições ideais para a absorção de anticorpos pelos bezerros como também para o fechamento intestinal. Pode-se citar que fatores presentes no colostro, substituição de células epiteliais absortivas do intestino delgado, mecanismos endócrinos, fatores estressores fisiológicos e do ambiente, prematuridade, desenvolvimento gástrico e início da ingestão de alimentos sólidos contribuem para o início do processo de fechamento (Jeffcott, 1972; Bush \& Staley, 1980; Kruse, 1983; Quigley et al., 1995b).

Michanek et al. (1989), estudando o processo de fechamento do intestino delgado em bezerros recém-nascidos, concluíram que o processo parece começar a partir da primeira refeição, sugerindo ainda que a ingestão precoce de colostro pode iniciar o fechamento somente se grandes quantidades de imunoglobulinas forem fornecidas. Em trabalho posterior, os autores estudaram a influência da ingestão de leite antes do colostro, experimento que reflete as condições de muitos sistemas de criação em que 0 animal recémnascido, ao ter contato com outras vacas, pode ingerir leite antes do colostro. Os autores concluíram que a ingestão de leite previamente ao colostro não influiu na mudança de permeabilidade intestinal às macromoléculas do colostro (Michanek et al., 1990).

\subsubsection{Fatores que Influem no Processo de Absorção}

Segundo Edwards et al. (1982), não há evidências de seletividade 
individual quanto à capacidade de absorção no animal recém-nascido. Portanto, o que assegura ao animal uma adequada transferência de imunidade passiva é o manejo eficiente nas primeiras horas de vida.

Vários trabalhos relatam os inúmeros fatores que podem influenciar a absorção de lg pelo recém-nascido. Dentre esses fatores, os que apresentam maior importância são concentração de imunoglobulinas no colostro, quantidade total de imunoglobulinas ingeridas por unidade de peso vivo e tempo entre o nascimento e a primeira refeição. $A$ interação desses fatores, afetando a concentração sérica de imunoglobulinas, tem sido estudada em vários experimentos.

Alguns trabalhos indicam que a separação imediata do bezerro da mãe após o nascimento poderia gerar uma situação de estresse para o animal, que determinaria a diminuição da concentração de lg sérica. Selman et al. $(1971)^{1}$, citado por Stott et al. (1979c), relacionaram as altas concentrações de imunoglobulinas em bezerros que permanecem com suas mães com três fatores: 1) em muitos casos, a primeira mamada do animal separado da mãe ocorre seis horas após o nascimento; 2) as quantidades de colostro consumidas geralmente são maiores quando comparadas às quantidades tradicionalmente oferecidas; e 3) os bezerros deixados com suas mães são mais eficientes, resultado do trato que recebem. Stott et al. (1979c) compararam animais que permaneceram com suas mães com o fornecimento da primeira refeição em mamadeira e, apesar de encontrarem grande variabilidade nos niveis de imunoglobulinas adquiridas em animais que permaneceram com a mãe, encontraram, também, taxas mais altas de absorção. Os autores sugeriram que

\footnotetext{
${ }^{1}$ SELMAN, I.E.; McEWAN, A.D.; FISHER, E.W. Studies on dairy calves allowed to suckle their dams at fixed times pospartum. Research in Veterinary Science, v.12, n.1, 1971.
} 
haveria algum fator no colostro mamado diretamente das mães que agiria como um mensageiro estimulando a atividade das células intestinais e 0 rápido transporte das macromoléculas do colostro através das células para a circulação.

Quigley et al. (1995a), trabalhando com bezerros da raça Jersey, observaram que os animais que permaneceram com as mães tiveram maiores concentraçöes de IgG e IgM às 24 horas de vida do que os animais que mamaram em mamadeiras. Os autores justificam o resultado pelo fato dos animais que permaneceram com as mães terem acesso a uma maior quantidade de colostro do que os animais alocados no grupo que recebeu um litro de colostro via mamadeira.

Outros trabalhos encontraram prejuizo quando os animais permaneceram com suas mães. Os principais fatores envolvidos com a dificuldade do animal em mamar quando deixado com a mãe seriam: rejeição do recém-nascido pela mãe, conformação do úbere e tetos e vigor do animal recém-nascido, principalmente em função de dificuldades de parto (Rajala \& Castren, 1995).

Segundo Brignole \& Stott (1980), 20 a $40 \%$ dos animais que permanecem com suas mães são agamaglobulinêmicos. Os autores encontraram concentraçōes, às 24 horas de vida, que variaram de zero a $63 \mathrm{mg}$ de $\mathrm{lgG} / \mathrm{mL}$ em bezerros leiteiros que permaneceram com suas mães. Já Robison et al. (1988) estudaram 1000 bezerras que permaneceram com suas mães por 24 horas após o nascimento. Esses animais apresentaram nível médio de imunoglobulinas de $25,71 \mathrm{mg} / \mathrm{mL}$ entre 24 e 48 horas de vida, com amplitude de variação de 0,05 a $108,27 \mathrm{mg} / \mathrm{mL}$.

Jenny et al. (1981) observaram diminuição da mortalidade dos 
animais nos primeiros meses de vida quanto mais cedo eram separados da mãe após o parto. Do nascimento até seis meses de idade a mortalidade no primeiro mês de vida correspondeu a $84 \%$ da mortalidade total.

Besser et al. (1991) avaliaram três métodos de fornecimento de colostro em três rebanhos. O uso de sonda esofagiana, de mamadeira ou animais deixados com as mães resultaram em 10,8, 19,3 e 61,4\%, respectivamente, de bezerros com falha de transferência de imunidade passiva (concentração de lgG menor que $10 \mathrm{mg} / \mathrm{mL}$ ), às 48 horas de vida. Afirmaram, ainda, que no caso do aleitamento natural o principal fator que influenciaria a transferência de imunidade passiva seria o volume ingerido pelo animal recémnascido e, no caso de aleitamento artificial, a concentração total de imunoglobulinas fornecidas.

A conformação do úbere e tetos também pode contribuir para 0 atraso da primeira mamada dos bezerros recém-nascidos que permanecem com suas mães. Robison et al. (1988) observaram que vacas mais velhas (três a sete anos de vida) podem deixar de apresentar uma conformação ideal do úbere, dificultando a primeira mamada. Ventorp \& Michanek (1992), estudando a conformação de úbere de vacas e novilhas, verificaram que os bezerros têm maior dificuldade de mamar em úberes muito baixos, porém o tamanho dos tetos, conformação e localização dos mesmos não interferiram no sucesso da primeira mamada.

Segundo Kruse (1970) e Oyeniyi \& Hunter (1978), outro fator importante a ser considerado seria a idade dos animais, já que vacas Holandesas nas três primeiras parições possuem concentrações de imunoglobulinas semelhantes no colostro. Lucci (1989) verificou que vacas ao redor do $4^{\circ}$ parto possuem um colostro de melhor qualidade do que vacas primiparas. Machado Neto et al. (1997a) encontraram concentração média de 
IgG inferior em bezerros nascidos de vacas primíparas comparados a bezerros nascidos de vacas com idade superior. Esse fato é explicado pela menor produção de colostro e com menor concentração de imunoglobulinas, encontradas em vacas nas parições iniciais.

Dois fatores essenciais que determinam a quantidade de imunoglobulinas absorvidas seriam o tempo decorrido do nascimento até a primeira refeição de colostro e a concentração de imunoglobulinas no mesmo.

Com o aumento da idade do animal há um decréscimo na taxa de absorção das imunoglobulinas pelas células intestinais. Comline et al. (1951) relataram que quando colostro bovino foi introduzido no duodeno de bezerros recém-nascidos que não ingeriram colostro com 8-12 horas de vida as imunoglobulinas não eram encontradas na circulação em níveis adequados. Stott et al. (1979a) observaram que $50 \%$ dos animais que receberam colostro 24 horas após o nascimento falharam em absorver imunoglobulinas, fato não verificado em animais que mamaram antes das 12 horas. Pires et al. (1993), encontraram concentrações mais altas de lg no soro de bezerros que mamaram o colostro até duas horas após o nascimento e por um período superior a 30 minutos. Rajala \& Castren (1995) observaram que um atraso de 30 minutos no fornecimento da primeira refeição de colostro proporcionou um decréscimo na concentração sérica de $2 \mathrm{mg} / \mathrm{mL}$.

Matte et al. (1982) avaliaram a porcentagem de absorção das imunoglobulinas adquiridas do colostro em diferentes períodos e observaram que $65,8 \%$ das imunoglobulinas ingeridas estavam presentes no plasma quando colostro foi fornecido até seis horas após o nascimento. A porcentagem declinou rapidamente para $46,9 \%, 11,5 \%, 6,7 \%$, e $6,0 \%$ quando colostro foi fornecido às 12, 24, 36 e 48 horas, respectivamente. Edwards et al. (1982) 
também não encontraram falhas de absorção em animais que haviam recebido colostro nas primeiras sete horas de vida.

Kruse (1970) avaliou 141 bezerros de várias raças quanto ao coeficiente de absorção de imunoglobulinas. $O$ autor relatou que o coeficiente decresce à medida em que se aumenta o período entre 0 nascimento até a primeira refeição do colostro, e atribuiu mais de $50 \%$ da variação na absorção à quantidade de imunoglobulinas ingeridas na primeira refeição. Bush et al. (1971), trabalhando com 27 animais de quatro raças diferentes, calculou que 45\% da imunoglobulina ingerida nas duas primeiras refeições estavam presentes no soro às 24 horas, e atribuiu aproximadamente $68 \%$ da variação na absorção das imunoglobulinas às quantidades consumidas por unidade de peso vivo.

Stott et al. (1979b) observaram que a quantidade de colostro ingerida e a idade da primeira refeição afetaram a taxa de absorção. Foi observado que os bezerros que consumiram 0,5 e um litro de colostro ao nascimento responderam à segunda refeição; entretanto, os animais que receberam dois litros não foram capazes de responder a segunda refeição às 12 horas de vida. Os autores concluíram que o fornecimento de 0,5 e um litro de colostro após o nascimento não ativou o mecanismo endocítico em todo o potencial das células absortivas intestinais, indicado pelo fato da segunda refeição às 12 horas de vida ter causado aumento nas taxas de absorção. No entanto, quando quantidades adicionais são fornecidas atinge-se a máxima atividade das células e transferência para a circulação, mostrando que a capacidade das células epitelias é limitada. $O$ resultados obtidos por Besser et al. (1985) concordam com essa afirmação, uma vez que os autores verificaram correlações negativas entre eficiência de absorção e a massa de $\lg _{1}$ fornecida aos bezerros recém-nascidos, sugerindo a existência de uma limitação 
fisiológica à transferência de grandes massas de $\lg _{1}$ para o soro dos animais.

Stott \& Fellah (1983) encontraram correlação linear positiva entre a concentração sérica de $\lg$ e e $\lg A$ em bezerros às 24 horas de vida e a concentração dessas imunoglobulinas no colostro. Trabalhando também com volumes de um ou dois litros com a mesma massa de imunoglobulinas, encontraram que o volume apresenta menor influência sobre a absorção de Ig do que a concentração de imunoglobulinas do colostro.

Besser et al. (1991) sugeriram que, para minimizar a falha de transferência de imunidade passiva nos rebanhos leiteiros, os animais deveriam receber grandes volumes de colostro, como três a quatro litros. Gay (1994) também observou que o volume geralmente oferecido aos animais, dois litros na primeira refeição, não proporcionaria uma quantidade de imunoglobulinas suficiente em uma significativa porcentagem de animais, devido à grande variação na concentração de imunoglobulinas no colostro oferecido. Esse autor recomendou, ainda, o uso de sonda esofagiana para facilitar e assegurar a administração de grandes volumes. Em estudo recente, Morin et al. (1997) estudaram os efeitos da qualidade, quantidade e tempo de administração do colostro. Foi encontrado que a absorção de $\lg _{1}$ foi aumentada sempre quando mais de quatro litros de um colostro com altas concentrações de lg foram oferecidos até três horas após o nascimento. Os animais que ingeriram quatro litros de colostro com altas concentrações de $\mathrm{lg}$ receberam $50 \%$ a mais de imunoglobulinas totais às 12 horas do que aqueles que haviam recebido somente dois litros de colostro, tanto com altas como com baixas concentrações de lg. Os autores indicaram vantagem na administração de altos volumes de colostro de boa qualidade, o que não causaria desconforto ao animal e nenhuma evidência de distúrbios gastrointestinais. 
Outros fatores que podem interferir na eficiência com que os bezerros recém-nascidos absorvem imunoglobulinas do colostro foram avaliados por vários autores. Besser et al. (1990) relacionaram que a estação do ano, o estresse, a presença da mãe, o status endócrino do bezerro, o peso ao nascer e o status ácido-base do bezerro poderiam interferir na absorção de imunoglobulinas pelos bezerros recém-nascidos. Perino \& Wittun (1995) trabalharam com 263 animais e associaram vários fatores a concentração inicial de imunoglobulinas absorvidas nos animais. Bezerros de mães que apresentavam mastite e que nasceram de parto distócico apresentaram baixa concentração inicial de imunoglobulinas séricas, fato que já havia sido verificado por Donovan et al. (1986). Nesse mesmo estudo verificaram, também, que a condição corporal da mãe, o peso ao nascimento e o sexo do bezerro não apresentaram correlação com os valores iniciais de proteína sérica total ou níveis de lgG, o que concorda com os resultados obtidos por Pires et al. (1993).

\subsection{Transição da Imunidade Passiva para Ativa e Desempenho}

No bezerro recém-nascido, a imunidade passiva derivada do colostro alcança um pico de concentração na corrente sanguínea entre 24 e 48 horas (Bush et al., 1971; Husband et al., 1972; Logan et al., 1978; Kruse, 1983; Ribeiro et al., 1983; Borges, 1997). McCoy et al. (1970), observando animais recém-nascidos durante as primeiras sete horas e meia de vida, relataram níveis pré-colostrais de $0,2 \mathrm{mg} / \mathrm{mL}$ de imunoglobulinas séricas. Essa quantidade aumentou linearmente para $1,9 \mathrm{mg} / \mathrm{mL}$, sete horas e meia após terem recebido a primeira refeição de colostro.

Após 24 horas, a concentração média das imunoglobulinas

adquiridas passivamente tende a decrescer, refletindo o catabolismo do 
material ou transferência para outros "pools" metabólicos. Após o periodo de declínio verifica-se uma aumento gradativo das imunoglobulinas devido a sintese endógena (Tennant et al., 1969; Bush et al., 1971; Husband et al., 1972; Logan et al., 1978; Ribeiro et al., 1983; Machado Neto \& Packer, 1986).

Esse caminho seguido pela imunidade passiva enfatiza a vulnerabilidade do animal jovem nesse periodo quando é exposto a uma variedade de diferentes agentes estressantes (Blecha et al., 1983). As imunoglobulinas adquiridas passivamente parecem reprimir a produção endógena precoce de anticorpos (Husband \& Lascelles, 1975; Porter, 1979; Machado Neto \& Packer, 1986; Baracat et al., 1997; Aldridge et al., 1998).

Em bezerros privados de colostro e desafiados, estudos mostram uma grande variação na resposta humoral, dependendo do antígeno administrado e, em muitos casos, a resposta humoral não é evidenciada até várias semanas de idade. Esses dados indicam que, embora haja alguma resposta primária à exposição do animal a um desafio, o recém-nascido não é suficientemente apto para gerar uma expansão na população de células $T$ de memória nas primeiras semanas de vida (Arthington, 1997). Devery et al. (1979) verificaram capacidade de produção endógena de $\lg \mathrm{G}_{1}$ em bezerros nas três primeiras semanas de vida, sendo a taxa de produção $1 \mathrm{~g} \mathrm{lgG}_{1} / \mathrm{dia}$, sugerindo que a mesma depende do desafio antigênico ao qual o animal é exposto no início da vida. Aldridge et al. (1998) não encontraram células produtoras de $\lg _{1}$ e $\lg G_{2}$ em tecidos linfóides de bezerros alimentados com colostro entre 36 e 48 horas de vida, em contraste a animais que não receberam a primeira refeição de colostro. Esses resultados demonstraram que a ingestão de colostro reduz o número de células produtoras de imunoglobulinas nos tecidos linfóides de bezerros recém-nascidos. 
Husband et al. (1972) consideraram entre 16 e 32 dias a meia-vida para $\lg _{1}$ e $\lg G_{2}, 4$ dias para $\lg M$ e 2,5 dias para $\lg A$. Após a fase inicial de declínio, a qual chamaram de declínio biológico das imunoglobulinas, os autores verificaram um aumento gradativo das imunoglobulinas. No entanto a produção endógena não trouxe contribuição significativa até uma a duas semanas após o nascimento, por ser ainda menor do que a taxa de catabolismo dos anticorpos maternos. Os autores concluiram que a produção endógena de $\lg G_{1}, \lg _{2}$ e $\lg M$ inicia-se entre oito a 16 dias após o nascimento e aos 64 dias para IgA. Segundo Porter (1972), as imunoglobulinas IgG, IgM e IgA, adquiridas passivamente, possuem meia vida de 20,4 e 2 dias, respectivamente, concordando com estudo desenvolvido por McGuire et al. (1976).

Ribeiro et al. (1983) verificaram um decréscimo na concentração sérica de imunoglobulinas até 21 dias de idade. Segundo Logan et al. (1974) animais com altas concentrações iniciais de imunoglobulinas exógenas retardariam a síntese endógena de imunoglobulinas, enquanto os animais com baixos valores iniciais antecipariam sua produção, resultados similares foram encontrados por Husband \& Lascelles (1975). McGuire et al. (1976), trabalhando com animais de corte, observaram que animais hipogamaglobulinêmicos iniciaram a atividade de sintese de anticorpos na primeira semana de vida, enquanto os animais com altas concentrações ainda não haviam iniciado a produção endógena na quarta semana de vida.

Machado Neto \& Packer (1986), Daniele et al. (1994a) e Baracat et al. (1997), trabalhando com animais com altas concentrações iniciais de imunoglobulinas passivas, em média $40 \mathrm{mg} / \mathrm{mL}$, verificaram um maior período de declínio nas curvas de flutuação de IgG, entre 40 e 60 dias de idade. Rajala \& Castren (1995), comparando animais com altas e baixas concentrações iniciais de $\lg G$, concluiram que a concentração de imunoglobulinas dos animais 
com baixa imunidade inicial começou a aumentar por volta das duas semanas, mas a concentração dos animais com alta imunidade passiva continuou decrescendo até duas semanas de idade.

A proteína total sérica (PT) em bezerros recém-nascidos segue um padrão de variação semelhante ao das imunoglobulinas. Ao nascer o bezerro apresenta níveis baixos de proteína total, atingindo o pico, em média, no $4^{\circ}$ dia de vida, diminuindo em seguida até se estabilizar (Fagliari et al.; 1983; Nocek et al., 1984; Daniele et al., 1994b; Bessi, 1996).

Tennant et al. (1969), estudando a concentração de PT sérica em bezerros das raças Jersey e Holandesa, não encontraram mudança significativa entre a $2^{\mathrm{a}}$ e a $6^{\mathrm{a}}$ semanas de vida, mas a concentração aumentou entre a $7^{\mathrm{a}}$ e a $16^{a}$ semanas. A concentração plasmática alcançou valor máximo aos três dias de idade para animais Jersey e aos cinco dias para animais Holandeses. Avaliou-se, também, a concentração de albumina, que se manteve estável entre $2,3 \pm 0,2 \mathrm{mg} / 100 \mathrm{~mL}$ no período pré-colostral até $3,1 \pm 0,2 \mathrm{mg} / 100 \mathrm{~mL}$ no período entre 120-210 dias de idade. Valores similares de PT sérica e albumina foram obtidos nos estudos de Daniele et al. (1994b) e Baracat et al. (1995).

A exposição de animais a substâncias estranhas ao organismo pode resultar em severas alterações no seu funcionamento normal, mudanças metabólicas associadas com doenças infecciosas ou processos inflamatórios que implicam em decréscimo no ganho e na eficiência alimentar. Os nutrientes ingeridos são redistribuídos fora do processo de crescimento no sentido de apoiar o funcionamento do sistema imune.

A resposta geral do sistema à invasão de substâncias estranhas ao organismo envolve a liberação de uma série de substâncias denominadas linfocinas, que iniciam a atividade celular e humoral, alterando também vários 
processos metabólicos, diminuem o consumo voluntário e aumentam a produção de calor corporal. Também, observa-se uma redução na taxa de crescimento dos tecidos, particularmente muscular e esquelético. A síntese de proteina corporal é reduzida, enquanto sua degradação é aumentada, como parte da defesa contra a invasão de antígenos. Esses ajustes metabólicos resultam em redução da taxa de crescimento corporal e menor eficiência da utilização da dieta para crescimento (Stahly, 1994).

Estudos realizados recentemente procuram avaliar 0 efeito da minimização da taxa de ativação do sistema imune em alguns animais, relacionando eficiência e composição do crescimento na fase inicial de vida. Van Heugten et al. (1994) conduziram um estudo para avaliar o efeito específico da estimulação do sistema imune no desempenho e na exigência de proteína de porcos jovens em crescimento, usando um agente desafiador e diferentes níveis protéicos dos 7 aos 21 dias de idade. Os autores concluíram que não houve diferenças quanto às exigências protéicas entre os animais desafiados e os animais controle após ou durante o desafio imunológico, mas propuseram que 0 aumento da taxa metabólica associada à inflamação pode reduzir a energia disponivel para deposição de proteína nos tecidos, o que explicaria a redução na eficiência da utilização da proteína em porcos que foram imunologicamente desafiados. Klasing et al. $(1987)^{2}$, citado por Van Heugten et al. (1994), encontraram um decréscimo no ganho de peso, consumo e eficiência da utilização da dieta em aves que foram repetidamente desafiadas com agentes não infecciosos.

Willians et al. (1993a) avaliaram o impacto da ativação do sistema

2 KLASING, K.C.; LAURIN, D.E.; PENG, R.K.; FRY, D.M. Immunological mediated growth depression in chicks: Influence of feed intake, corticosterone and interleukin-1. Journal of Nutrition, v.117, p.1629, 1987. 
imunológico em suínos, divididos em dois grupos: desmama precoce medicada (11 dias de idade), a qual representava o grupo de baixa ativação, enquanto que a desmama convencional (19 dias de idade), representava alta ativação. Baseados nos dados obtidos, os autores concluíram que os animais do grupo de baixa ativação do sistema imune tiveram uma maior capacidade para o crescimento de tecido e uma maior necessidade de aminoácidos na dieta do que aqueles de alta ativação. Em outro estudo, Willians et al. (1993b) avaliaram - impacto da ativação do sistema imune em animais dos 28 aos 59 dias de idade. Os animais no grupo de ativação baixa consumiram mais ração e tiveram maior ganho de peso. Os resultados apresentados são semelhantes aos encontrados por Stahly et al. (1994), no qual os autores, também utilizando suínos provenientes de dois sistemas de desmama, concluíram que os animais que estavam alocados ao grupo de baixa ativação do sistema imune melhoraram o ganho diário, bem como as taxas de ganho de peso.

Blecha et al. (1983) avaliaram a influência da desmama de suínos em quatro idades diferentes sobre a resposta imune mediada por células. Os autores concluíram que a desmama antes de cinco semanas pode causar mudanças fisiológicas prejudiciais à atividade imunológica celular. Em contradição a esse experimento, Crenshaw et al. (1986) encontraram resultados que sugerem que as respostas imunológicas celular e humoral não são prejudicadas pela desmama precoce, restrição alimentar ou temperatura. De acordo com os autores, os resultados são contraditórios pelo fato de que, na prática, outros fatores poderem comprometer a imunidade, interagindo com aqueles estudados.

Em bezerros não se sabe até que ponto niveis de imunização passiva que determinam a baixa ativação do sistema imune endógeno poderiam influenciar o desempenho, considerando a fase inicial de crescimento. 
Teoricamente, ocorrendo diminuição da incidência de diarréia e outras doenças neonatais, modulado pela imunização passiva adequada, haveria melhor desempenho do animal. No trabalho de Zanetti (1990), os bezerros receberam colostro suplementar até o quinto dia de vida e obtiveram um ganho médio diário de $0,132 \mathrm{~kg}$, sendo que o autor não encontrou qualquer correlação entre ganho de peso no período e o nível de imunoglobulina, postulando que existiriam outros fatores de maior importância atuando nessa fase.

Vários estudos demonstraram que fornecendo colostro de alta qualidade, permitindo que os animais adquiram niveis séricos iniciais de imunoglobulinas superiores a $30 \mathrm{mg} / \mathrm{mL}$, há uma diminuição da incidência e da severidade das diarréias que ocorrem nas primeiras semanas de vida (Snodgrass \& Wells, 1978, Nocek et al., 1984). Bessi (1996) encontrou uma maior incidência de diarréia em animais com concentração média inicial de lgG de 20,5 $\pm 0,21 \mathrm{mg} / \mathrm{mL}$ em comparação a animais com niveis superiores a 35 $\mathrm{mg} / \mathrm{mL}$. A autora sugere que os animais com menor nível de anticorpos adquiridos passivamente possuiam uma condição que poderia ter prejudicado a proteção contra patógenos intestinais no período de 11 a 20 dias de idade. Já Daniele et al. (1994a), trabalhando com suplementação de colostro em animais que não diferiram em relação ao nível inicial de imunoglobulinas (média de $\mathbf{4 0}$ $\mathrm{mg} / \mathrm{mL}$ ), obtiveram melhor desempenho quanto à diarréia em animais suplementados com colostro duas vezes ao dia, em um período de 30 dias, do que em animais não suplementados. Os autores sugerem que a proteção local foi mais importante do que a sistêmica e que a alta concentração de anticorpos séricos não foi capaz de manter os animais livres de doenças, podendo apenas ter contribuído para que elas não atingissem elevados níveis de severidade. Resultados similares foram encontrados por Baracat et al. (1997).

Quanto ao desempenho Edwards et al. (1982), Lopez et al. (1988) 
e Tood \& Whyte (1995) não encontraram correlação entre níveis séricos iniciais de anticorpos e ganho de peso nos primeiros meses de vida do animal. Nocek et al. (1984) observaram que o fornecimento de colostro com altas concentrações de imunoglobulinas não influenciou o ganho de peso de bezerros leiteiros entre 5 e 11 dias, como também entre 5 e 45 dias de idade. Bradley \& Nilo (1985), trabalhando com 62 bezerros de corte, também não encontraram resultados positivos na prática de suplementação com colostro uma hora após o nascimento e subsequente ganho de peso aos 42 dias de idade.

Caldow et al. (1988) encontraram correlação entre as concentraçōes de lgG aos 8-10 dias de idade e taxas de crescimento de bezerros aos 45 dias de idade. Já Robison et al. (1988) encontraram efeito positivo da concentração inicial de lgG sérica sobre a taxa de ganho de peso do nascimento até 180 dias de idade, sendo o efeito mais intenso de 70 a 105 dias de idade.

Quigley et al. (1995a) estudaram o efeito de diferentes tipos de alojamento e métodos de ingestão do colostro na incidência e severidade de diarréia, no consumo, no ganho de peso e na eficiência de ganho em bezerros recém-nascidos da raça Jersey. Os autores concluíram que os diferentes métodos de alojamento e ingestão do colostro podem afetar a incidência e severidade com que ocorre a diarréia e que 0 isolamento dos bezerros e a maximização da transferência de imunidade passiva, permitindo que os animais permaneçam com suas mães, pode aumentar o ganho de peso e melhorar a saúde dos animais.

Wittum \& Perino (1995) avaliaram o status imune de 263 bezerros com 24 horas de vida e correlacionaram a dados de desempenho dos animais. 
Os resultados encontrados indicam que uma inadequada transferência de imunidade passiva está diretamente associada com um maior risco de problemas de saúde antes e após a desmama, e indiretamente associado com morbidez e mortalidade no período pré-desmama. Os autores ainda ressaltam que é difícil explicar a razão biológica pela qual o status imunológico inicial do animal pode ser associado com doenças aos seis meses de idade, quando os bezerros são capazes de responder ativamente a agentes infecciosos. Tem sido postulado que a aquisição de uma adequada imunidade materna deve favorecer o desenvolvimento controlado de um sistema imunológico competente. Em outro estudo, em que utilizaram animais com falha na transferência de imunidade passiva (concentração menor que $4,8 \mathrm{~g}$ de proteína/100mL), foi determinado o efeito do colostro suplementar oferecido até as dez horas de vida. Os autores concluiram que o colostro suplementar, administrado aos animais com baixa concentração de proteína plasmática às dez horas de vida, não tem efeito na proteína plasmática ou valores de lgG às 24 horas ou ainda na mortalidade e morbidez pré-desmama (Perino \& Wittum, 1995).

Ramin et al. (1996) correlacionaram concentração de imunoglobulina sérica de 100 animais leiteiros de cinco rebanhos diferentes a ganho de peso, idade do início da puberdade e área pélvica aos quinze meses de idade. Os autores encontraram grande variação entre os bezerros quanto à concentração sérica de imunoglobulinas, que foi correlacionada a vários fatores como estação do ano que os animais nasceram, tempo da primeira amostragem (6-48 horas após o nascimento), entre outros fatores discutidos. No estudo, os autores não encontraram correlação entre a concentração de imunoglobulinas e ganho de peso até quinze meses de idade. Os autores observaram que os animais que apresentaram maiores concentrações séricas de imunoglobulinas obtiveram maiores taxas de crescimento e menor média de idade de início de 
puberdade; no entanto, em alguns rebanhos em que a concentração de imunoglobulinas inicial era baixa, também foram encontradas altas taxas de ganho de peso e rápida entrada na puberdade. Segundo os autores, a concentração de imunoglobulinas passivas possivelmente protege 0 animal por poucas semanas de idade mas não pode ser usada como um parâmetro apropriado para predizer o desempenho animal a longo prazo, sendo fatores relacionados ao manejo e ao ambiente os principais determinantes de um adequado desempenho animal nos primeiros meses de vida.

Machado Neto et al. (1997b) trabalharam com 603 bezerros, de quatro diferentes raças (Nelore, Guezerá, Gir e Caracu), e correlacionaram concentração inicial de IgG sérica obtidas entre 24 e 48 horas de vida e peso dos animais aos 120 e 210 dias de idade. Os autores observaram efeito significativo da lgG sérica sobre o peso dos bezerros aos $120(p=0,0001)$ e 210 dias $(p=0,0027)$ de vida. Os bezerros que morreram apresentaram concentração média de lgG sérica inferior $(p=0,034)$ à obtida para os bezerros sobreviventes.

Vários outros fatores têm sido estudados e relacionados com desempenho animal na fase inicial de crescimento até a desmama. Shell et al. (1995) estudaram os efeitos da nutrição e radiação solar, durante os dois terços finais da gestação na concentração de imunoglobulina $G$ e $M$ no colostro e, também, no soro em bezerros de corte. A nutrição materna no período pré-parto ou o ambiente não afetaram a produção de leite $e$, também, não influiram na concentração sérica de imunoglobulinas dos bezerros em niveis que poderiam trazer consequências em seu crescimento.

Hopkins (1997), trabalhando com duas idades de desmama em bezerros leiteiros, 28 e 56 dias, avaliou o método de fornecimento de 
concentrado inicial através de mamadeiras ou cochos abertos e relacionou ao crescimento. A forma de fornecimento do concentrado não afetou significativamente a ingestão, sendo que a mesma atingiu uma média de $17 \mathrm{~kg}$ semanalmente na desmama. O peso vivo não foi afetado pelo método de ingestão do concentrado, sendo que os animais desmamados com 28 dias atingiram $54,4 \mathrm{~kg}$ de peso vivo médio e os desmamados com 56 dias, de 65,0 $\mathrm{kg}$.

Lance et al. (1992) e Losinger \& Heinrichs (1997) estudaram a causa de mortalidade na fase pré-desmama em rebanhos leiteiros e encontraram que tamanho do rebanho, desinfecção do umbigo do recémnascido, tipo de alojamento, consumo de forragem nos primeiros 20 dias de vida, consumo de leite com mastite ou antibiótico e tratamento de diarréia afetaram a mortalidade, e que essas variáveis explicavam aproximadamente $39 \%$ da variação da mortalidade entre rebanhos. Jenny et al. (1981) citou que pessoa responsável, tempo que o animal permanece com a mãe e idade de desmama podem influenciar a mortalidade.

Como fica evidente, os trabalhos que relacionam desempenho, transferência de imunidade passiva e ativação do sistema imunológico endógeno em bezerros não são conclusivos devido a diversos fatores. Há uma variação muito grande das condições experimentais nos diferentes trabalhos, diferenças no número de animais amostrados e diferença nas variáveis estudadas. Portanto, pode haver outros fatores relevantes atuando na fase inicial de desenvolvimento animal não considerados que possam ser determinantes na avaliação do desempenho animal nos primeiros meses de vida. 


\section{MATERIAL E MÉTODOS}

\subsection{Local}

A parte experimental de campo deste trabalho foi iniciada em fevereiro de 1997 na Fazenda Tainá - municipio de São Pedro, Estado de São Paulo. No periodo de fevereiro a julho de 1997 foram obtidas amostras de 28 animais na Fazenda Tainá. Em setembro de 1997 as amostragens tiveram continuidade nas instalaçōes do Departamento de Produção Animal da Escola Superior de Agricultura "Luiz de Queiroz", municipio de Piracicaba, Estado de São Paulo. De setembro de 1997 a agosto de 1998 foram amostrados 31 animais na Fazenda Experimental. Ambas as fazendas adotavam práticas de manejo semelhantes nos dois primeiros meses de vida do animal.

As análises laboratoriais foram realizadas no Laboratório de Anatomia e Fisiologia Animal (LAFA) do já referido Departamento de Produção Animal. 


\subsection{Animais}

Nesse experimento foram utilizadas bezerras recém-nascidas da raça Holandesa. Após o nascimento as bezerras eram separadas de suas mães e trazidas ao bezerreiro sendo mantidas em baias individuais até 60 dias de idade, com o término do aleitamento.

As bezerras recebiam colostro materno durante os dois primeiros dias de vida, através de mamadeira. A seguir as bezerras passaram a receber 4 litros de leite em duas refeições diárias, oferecidas em balde. Além da dieta líquida, tinham à disposição desde o primeiro dia de vida água, concentrado inicial, feno e/ou pastejo.

O experimento não interferiu no manejo sanitário dos rebanhos, havendo inspeção veterinária e tratamento dos animais com pneumonia e diarréia. Em ambos os manejos os animais que apresentavam diarréia eram tratados com solução de sais para hidratação oral e restringia-se o leite da dieta. Em casos graves de diarréia e pneumonia, comprovados por diagnóstico veterinário, fornecia-se antibióticos.

A desmama abrupta foi efetuada aos 60 dias de idade, de acordo com o consumo de ração. Os animais foram então agrupados em baias coletivas.

\subsection{Grupos}

No total foram amostradas 59 bezerras separadas, posteriormente, em três grupos experimentais de acordo com a concentração inicial de imunoglobulinas séricas adquiridas passivamente, fazendo com que desse 
modo houvesse uma menor variação entre as parcelas experimentais.

As concentrações adotadas para a separação dos grupos experimentais visou formar grupos com valores extremos. Em função da disponibilidade de animais e status imunológico inicial, a ordem dos grupos ficou determinada de acordo com a Tabela 3 mostrada a seguir.

Tabela 3. Classificação dos animais de acordo com a concentração inicial de imunoglobulinas séricas.

Grupos

Concentração Inicial Número de Unidades

de lgG Sérica Experimentais

Grupo 1 - nível baixo

até $20 \mathrm{mg} / \mathrm{mL}$ de $\lg G$

26

Grupo 2 - nível médio

entre 20 e $30 \mathrm{mg} / \mathrm{mL}$ de $\lg \mathrm{G}$

15

Grupo 3 - nivel alto

acima de $30 \mathrm{mg} / \mathrm{mL}$ de $\lg \mathrm{G}$

18

Total de unidades experimentais

59

\subsection{Amostragem de Sangue}

Foram coletadas amostras de sangue de cada bezerra, retiradas da veia jugular (aproximadamente $10 \mathrm{~mL}$ ) e recebidas em tubo de centrífuga, sendo o sangue centrifugado e o soro resultante de cada amostra transferido para três frascos devidamente identificados, mantidos a temperatura de $-20^{\circ} \mathrm{C}$ até serem analisados. As amostras de sangue de cada animal foram retiradas nas seguintes idades: $1 ; 5 ; 10 ; 15 ; 17 ; 20 ; 25 ; 30 ; 35 ; 40 ; 45 ; 50$ e 60 dias.

\subsection{Desempenho}

O peso corporal dos animais foi registrado ao nascimento e nas 
seguintes datas experimentais: $5 ; 10 ; 15 ; 17 ; 20 ; 25 ; 30 ; 35 ; 40 ; 45 ; 50$ e 60 dias de idade.

Como concentrado inicial foram utilizadas rações comerciais. A composição dos concentrados utilizados nas fazendas são apresentadas nas Tabelas 1 e 2 do Apêndice. As bezerras tinham a sua disposição água, concentrado inicial, feno e/ou pasto, desde o primeiro dia de idade. No caso da Fazenda Tainá, as bezerras não recebiam qualquer tipo de volumoso suplementar tendo a disposição somente o pastejo em volta da baia individual. Nas instalações do Departamento de Produção Animal da ESALQ, os animais tinham a disposição feno de "coast-cross". O consumo de feno dos animais do referido departamento encontra-se na Tabela 15 do Apêndice. A oferta de ração foi feita de acordo com a idade do animal (até $2,0 \mathrm{~kg}$ por animal/dia). $O$ consumo de ração e feno eram anotados periodicamente, sendo as sobras pesadas e as quantidades oferecidas repostas.

\subsection{Análise das Amostras}

A fração lgG sérica das bezerras foi quantificada pelo método de imunodifusão radial, técnica descrita por Mancini et al. (1965), que se baseia na leitura do diâmetro formado pela reação do anticorpo da amostra com o anti lgG em meio de ágar, comparando-se com diâmetros padrões pré-estabelecidos. As amostras foram analisadas com repetição. Para a construção das curvas padrão foi utilizado lgG obtida da Sigma Chemical Company - USA. O ágar foi preparado com concentração de $1,2 \%$ de agarose em tampão TRIS- $\mathrm{HCl}(\mathrm{pH}$ $8,0)$ com anti-IgG obtido da Sigma Chemical Company - USA. Além das placas para as curvas padrão, todas as placas continham duas concentrações padrões para avaliação da variação entre as mesmas. As placas permaneciam em 
câmara úmida por 24 horas, a temperatura de $5^{\circ} \mathrm{C}$. Os diâmetros de precipitação foram medidos e registrados em milímetros. As amostras nas quais as medidas em duplicata variaram acima de $5 \%$ foram refeitas.

As equações obtidas seguiam o modelo abaixo:

$$
\begin{aligned}
& Y=a X+b, \text { em que; } \\
& Y=\text { concentração de lgG sérica em } \mathrm{mg} / \mathrm{mL} ; \\
& X=\text { diâmetro da reação }(\mathrm{mm}) .
\end{aligned}
$$

A quantificação da proteína total sérica foi determinada pelo método de biureto, segundo Reinhold (1953). Misturou-se $100 \mu \mathrm{L}$ da amostra do soro a $4,9 \mathrm{~mL}$ de $\mathrm{NaOH}(0,75 \mathrm{~N})$ e $1 \mathrm{~mL}$ de reagente de biureto. Após 20 minutos de reação procedeu-se a leitura da absorbância em espectrofotômetro com comprimento de onda ajustado em $545 \mathrm{~nm}$. Através de uma curva padrão pré-estabelecida com concentrações conhecidas de padrão de proteína (albumina bovina - Sigma Chemical Company - USA), relacionava-se os valores de absorbância obtidos das amostras. As amostras foram analisadas em duplicata, sendo o valor médio utilizado para se obter as concentrações de proteína sérica em $\mathrm{g} / 100 \mathrm{~mL}$ de soro.

\subsection{Delineamento Experimental e Análise Estatística}

O delineamento experimental foi inteiramente casualizado em parcelas subdivididas no tempo, sendo o efeito do nível inicial de imunoglobulinas aplicado às parcelas $e$ as medidas repetidas no tempo consideradas como subparcelas.

As análises estatísticas foram realizadas utilizando-se o programa SAS Estatístico (1989), em que as variáveis séricas foram submetidas a análise 
de variância para tal delineamento, procedendo-se, posteriormente, a análise de variância dentro de cada data experimental. Para tal análise foram usados dois procedimentos do programa SAS Estatístico, PROC GLM e PROC MIXED.

Para as variáveis peso, ganho de peso e consumo, foram feitas análises de variância e covariância utilizando-se 0 peso ao nascer e a concentração inicial de imunoglobulinas séricas como covariáveis, utilizandose, também, os procedimentos citados acima.

Para a avaliação de diferenças entre médias foram efetuados contrastes entre pares de médias utilizando-se o método de Tukey com nivel de significância de $5 \%(p<0,05)$ e contrastes entre médias obtidos pelo PROC MIXED.

Para PT e lgG foram calculados valores máximos e mínimos observados e idade de ocorrência desses valores, fazendo-se a análise de variância dos mesmos e comparação de médias pelo teste de Tukey $(p<0,05)$.

Análises de correlação, Pearson e Sperman, foram realizadas para verificar associações de interesse entre as variáveis $\mathrm{PT}$ e lgG.

Para determinar o comportamento das variáveis PT e lgG sérica ao longo do periodo experimental, para os três grupos, foram traçadas regressões não-lineares, as quais se mostraram mais adequadas para esse tipo de variável, obtendo-se uma curva para cada grupo, sendo o modelo da curva mostrado a seguir. 


$$
Y=L+U^{*}(R-I D)+V^{*}(I D-R)
$$

sendo que:

$$
\begin{aligned}
Y= & \text { concentração da variável; } \\
\text { ID }= & \text { idade dos animais (dias); } \\
\mathbf{L}= & \text { ponto de concentração mínima da variável; } \\
\mathbf{U}= & \text { coeficiente angular no período anterior ao ponto de } \\
& \text { concentração mínima; } \\
\mathbf{V}= & \text { coeficiente angular no período posterior ao ponto de } \\
& \text { concentração mínima; } \\
\mathbf{R}= & \text { idade no ponto de concentração mínima. }
\end{aligned}
$$

Seguiu-se o método DUD, um processo iterativo para se chegar ao critério de convergência, através do procedimento PROC NLIN (NonLinear) do SAS.

O processo iterativo requer uma seleção de valores iniciais dos parâmetros como ponto de partida para iterar segundo algum critério préestabelecido. Os valores iniciais adotados são apresentados nas Tabelas 4 e 5 apresentadas a seguir: 
Tabela 4. Valores iniciais dos parâmetros referentes a variável PT.

\begin{tabular}{ccccc}
\hline Grupos & L & U & V & R \\
\hline $\mathbf{1}$ & 5 & 0,1 & 0,1 & 10 \\
2 & 7 & $-0,2$ & 0,1 & 20 \\
3 & 7 & $-0,2$ & 0,1 & 20 \\
\hline
\end{tabular}

Grupo 1 nível baixo = até $20 \mathrm{mg} / \mathrm{mL}$ de $\mathrm{lgG}$

Grupo 2 nível médio $=$ entre 20 e $30 \mathrm{mg} / \mathrm{mL}$ de $\lg G$

Grupo 3 nivel alto $=$ acima de $30 \mathrm{mg} / \mathrm{mL}$ de $\lg G$

Tabela 5. Valores iniciais dos parâmetros referentes a variável lgG.

\begin{tabular}{ccccc}
\hline Grupos & $\mathbf{L}$ & $\mathbf{U}$ & $\mathbf{V}$ & $\mathbf{R}$ \\
\hline $\mathbf{1}$ & 12 & 0,2 & 0,2 & 25 \\
2 & 18 & $-0,2$ & 0,2 & 25 \\
3 & 20 & $-0,2$ & 0,2 & 30 \\
\hline
\end{tabular}

Grupo 1 nível baixo = até $20 \mathrm{mg} / \mathrm{mL}$ de $\lg G$

Grupo 2 nivel médio = entre 20 e $30 \mathrm{mg} / \mathrm{mL}$ de $\lg G$

Grupo 3 nivel alto = acima de $30 \mathrm{mg} / \mathrm{mL}$ de $\lg G$ 


\section{RESULTADOS E DISCUSSÃO}

\subsection{Proteína Sérica Total}

Os niveis médios de proteína sérica total (PT) das bezerras, distribuídas nos três grupos definidos com base na concentração de lgG inicial, nas diferentes idades, são apresentados na Tabela 6 e ilustrados na Figura 1. Os dados originais são apresentados nas Tabelas 3, 4 e 5 do Apêndice.

Os valores médios de PT observados no experimento estão de acordo com aqueles encontrados por Tennant et al. (1969); Husband et al. (1972); Machado Neto \& Packer (1986); Daniele et al. (1994a); Baracat et al. (1995) e Bessi (1996).

Através da análise de variância para o delineamento experimental em parcelas subdivididas, observou-se que as médias de PT sérica diferiram significatvamente entre os grupos $(p<0,0001)$ e datas experimentais $(p<0,0001)$. Também, a interação entre grupo e periodo foi significativa $(p<0,0001)$, indicando diferença de comportamento para essa variável entre os grupos nas várias determinações. 
Tabela 6. Concentração média de proteína total sérica $(\mathrm{g} / 100 \mathrm{~mL})$ nos grupos experimentais.

\begin{tabular}{cccc}
\hline $\begin{array}{c}\text { Idade } \\
\text { (dias) }\end{array}$ & $\begin{array}{c}\text { Grupo 1 } \\
\text { Média } \pm \text { DP }\end{array}$ & $\begin{array}{c}\text { Grupo 2 } \\
\text { Média } \pm \text { DP }\end{array}$ & $\begin{array}{c}\text { Grupo 3 } \\
\text { Média } \pm \text { DP }\end{array}$ \\
\hline $\mathbf{1}$ & $5,42 \pm 0,18$ & $7,46 \pm 0,21$ & $9,17 \pm 0,23$ \\
$\mathbf{5}$ & $5,96 \pm 0,21$ & $7,62 \pm 0,36$ & $8,42 \pm 0,19$ \\
10 & $6,25 \pm 0,18$ & $7,40 \pm 0,35$ & $8,13 \pm 0,19$ \\
15 & $6,01 \pm 0,13$ & $7,10 \pm 0,27$ & $7,60 \pm 0,19$ \\
17 & $5,93 \pm 0,14$ & $7,00 \pm 0,24$ & $7,37 \pm 0,17$ \\
$\mathbf{2 0}$ & $6,00 \pm 0,15$ & $7,01 \pm 0,26$ & $7,31 \pm 0,16$ \\
$\mathbf{2 5}$ & $6,10 \pm 0,12$ & $7,08 \pm 0,24$ & $7,24 \pm 0,11$ \\
30 & $6,13 \pm 0,14$ & $7,05 \pm 0,20$ & $7,34 \pm 0,16$ \\
$\mathbf{3 5}$ & $6,47 \pm 0,12$ & $7,19 \pm 0,23$ & $7,27 \pm 0,19$ \\
$\mathbf{4 0}$ & $6,32 \pm 0,16$ & $7,23 \pm 0,21$ & $7,41 \pm 0,22$ \\
$\mathbf{4 5}$ & $6,72 \pm 0,20$ & $7,54 \pm 0,26$ & $7,55 \pm 0,24$ \\
$\mathbf{5 0}$ & $6,87 \pm 0,16$ & $7,69 \pm 0,25$ & $7,65 \pm 0,33$ \\
$\mathbf{6 0}$ & $6,92 \pm 0,21$ & $7,97 \pm 0,29$ & $7,78 \pm 0,25$ \\
\hline
\end{tabular}

Grupo 1 nível baixo = até $20 \mathrm{mg} / \mathrm{mL}$ de $\lg G$

Grupo 2 nivel médio $=$ entre 20 e $30 \mathrm{mg} / \mathrm{mL}$ de $\lg G$

Grupo 3 nivel alto $=$ acima de $30 \mathrm{mg} / \mathrm{mL}$ de $\lg G$

$\mathrm{DP}=$ Desvio Padrão 


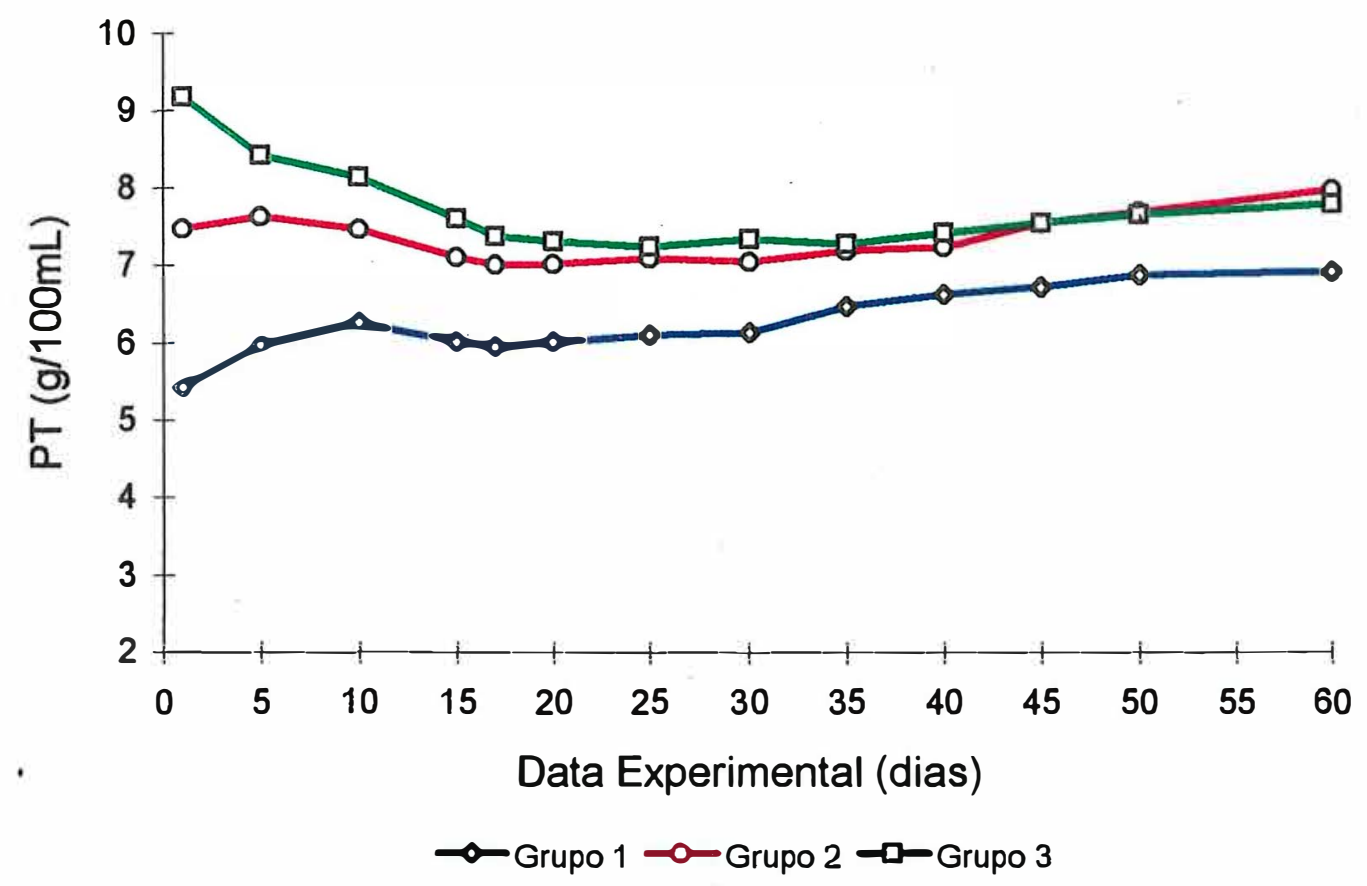

Figura 1. Flutuação da concentração média de proteina total sérica $(\mathrm{g} / 100 \mathrm{~mL})$ nos grupos experimentais.

Pela média geral obtida verificou-se que, nos animais às 24 horas de vida, as concentrações de PT foram significativamente superiores $(p<$ 0,0001 ) no grupo 3 , com média de $9,17 \pm 0,23 \mathrm{~g} / 100 \mathrm{~mL}$, quando comparados aos animais dos grupos 1 e 2 com médias 5,42 $\pm 0,18$ e 7,46 0,21 g/100mL, respectivamente. Essa diferença se manteve durante todo o periodo experimental entre os grupos 1 e 2 e 1 e 3 , sendo significativa somente até 10 dias de idade entre os grupos 2 e 3 . As probabilidades encontradas para a comparação entre os grupos nas datas experimentais encontram-se na Tabela 17 do Apêndice. 
Os valores finais para PT sérica, aos 60 dias de idade, para os grupos 2 e 3 , foram $7,97 \pm 0,29 \mathrm{~g} / 100 \mathrm{~mL}$ e $7,78 \pm 0,25 \mathrm{~g} / 100 \mathrm{~mL}$, respectivamente, que não diferiram significativamente $(p<0,7046)$. Nessa mesma idade, os animais do grupo 1 apresentaram concentração média de 6,92 $\pm 0,21 \mathrm{~g} / 100 \mathrm{~mL}$, valor significativamente inferior em relação aos valores do grupo $2(p<0,0026)$ e $3(p<0,0058)$.

As variáveis PT e imunoglobulinas séricas foram significativamente correlacionadas $(p<0,0001)$, considerando-se o periodo experimental total, com valor de $r=0,788$.

Foram encontradas correlações positivas entre as concentrações de PT e imunoglobulinas séricas no $1^{\circ}$ dia de vida, sendo $r=0,919(p<0,0001)$ para o grupo 1 e $r=0,702$ ( $p<0,0012)$ para $\circ$ grupo 3 ; no entanto, não foi encontrada correlação significativa nessa data para o grupo $2 r=0,418$ $(p<0,1208)$. Vários autores citam correlações positivas entre PT e imunoglobulina sérica nos primeiros dias de vida (Nocek et al., 1984; Machado Neto \& Packer, 1986; Dobbelaar et al., 1987; Baracat et al., 1995; Bessi, 1996).

A correlação decresceu, mas manteve-se significativa por todo o período experimental, exceto por volta dos 35 dias de idade, fato esse observado nos três grupos. Para $\circ$ grupo 1 aos 35 dias encontrou-se $r=0,243$ ( $p<0,2761$ ); para $\circ$ grupo 2 aos 30 dias $r=0,441$ ( $p<0,1136)$ e para $\circ$ grupo 3 aos 35 dias de idade $r=0,078$ ( $p<0,779$ ). Até esse período, de acordo com 0 agrupamento estabelecido e em função do catabolismo das imunoglobulinas adquiridas passivamente, houve um decréscimo na concentração de $\lg G$, minimizando a dependência das variáveis próximo a data de concentração mínima de lgG. 
Outra forma de demonstrarmos a influência dos níveis de IgG iniciais sobre PT seria desagregar esses valores dos obtidos para a variável PT no primeiro dia de vida, como pode ser visto na Tabela 7.

Quando o valor médio inicial de lgG sérica foi descontado do valor de PT, diminuem, consideravelmente, as diferenças entre os grupos. Esse resultado é explicado pelo fato dos grupos terem sido separados a posteriori em função da concentração inicial de anticorpos passivos, fração protéica que no início da vida do animal perfaz de 20 a $40 \%$ da proteína total sérica. Verificase, assim, que $\circ$ valor da variável PT depende significativamente das imunoglobulinas passivas adquiridas do colostro nas primeiras semanas de vida. 
Tabela 7. Concentração de PT sérica $(\mathrm{g} / 100 \mathrm{~mL})$ desconsiderando-se o valor de IgG inicial $(\mathrm{g} / 100 \mathrm{~mL})$.

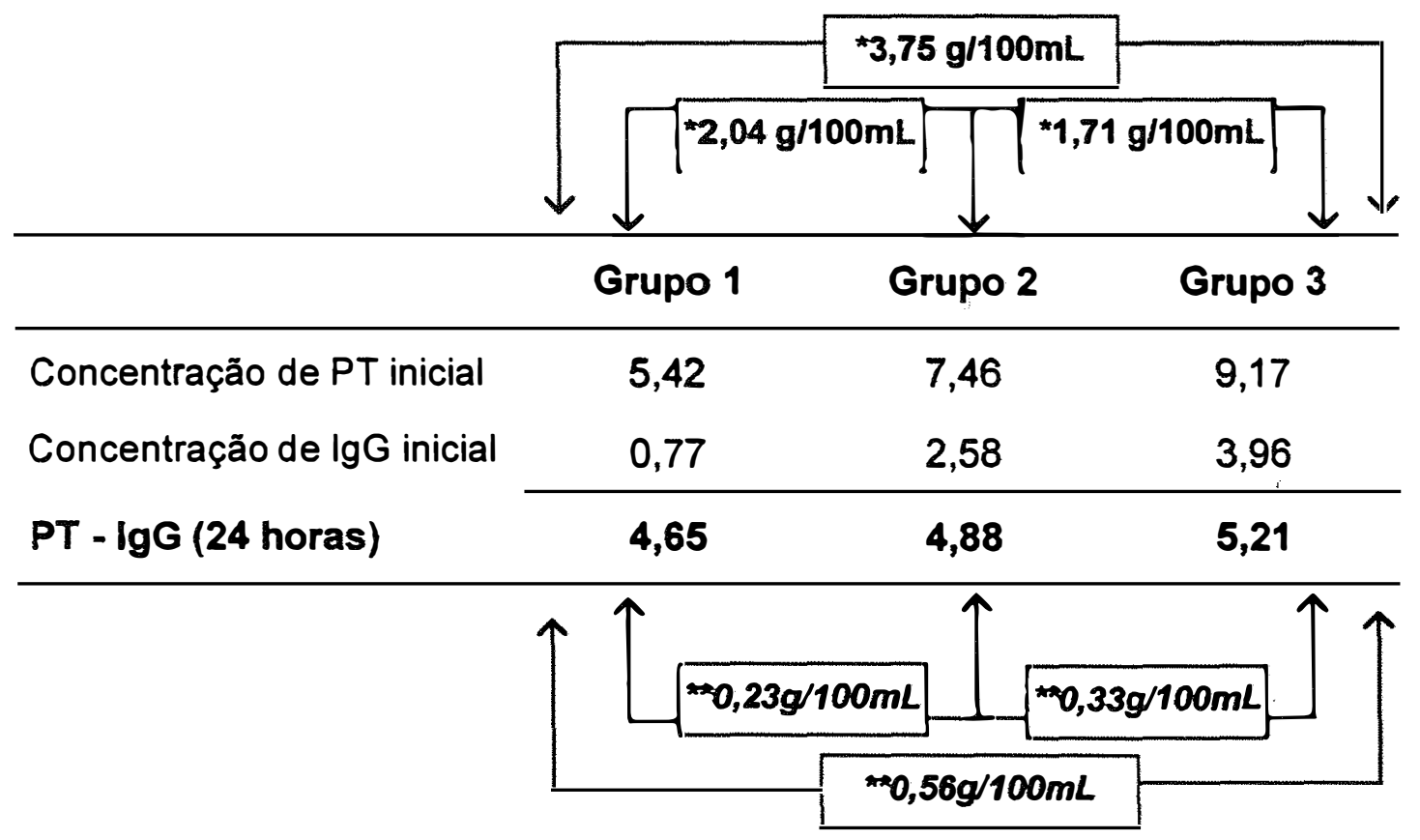

*Diferença na concentração sérica de PT entre os grupos às 24 horas

**Diferença na concentração sérica de PT entre os grupos desconsiderando os valores de lgG às 24 horas

Grupo 1 nivel baixo = até $20 \mathrm{mg} / \mathrm{mL}$ de $\lg G$

Grupo 2 nivel médio $=$ entre 20 e $30 \mathrm{mg} / \mathrm{mL}$ de $\lg G$

Grupo 3 nivel alto = acima de $30 \mathrm{mg} / \mathrm{mL}$ de $\lg G$ 
Para demonstrar o comportamento da PT sérica ao longo do período experimental para os três grupos, foram usadas regressões nãolineares obtendo-se uma curva para cada grupo, de acordo com a descrição no Material e Métodos.

O modelo geral da curva escolhido foi o que mais se adequou aos dados das variáveis séricas, já que o comportamento biológico das mesmas, nos primeiros meses de vida do animal, é caracterizado por uma fase de decréscimo, atingindo um valor mínimo, e uma fase de acréscimo, logo após esse valor ser atingido. Por se tratar de um modelo não-linear, foi necessário um processo iterativo para solucionar as equações. De acordo com Diaz (1992) - processo iterativo requer uma seleção de valores iniciais como ponto de partida para iterar segundo algum critério pré-estabelecido, dessa escolha, portanto, pode depender uma rápida ou lenta convergência. Não existem, entretanto, algorítimos para determinar valores iniciais adequados, devendo-se contar com algum conhecimento sugerido por pesquisas prévias, em situações experimentais semelhantes. No caso do modelo proposto não foram encontrados valores disponíveis em literatura, sendo escolhidos os valores iniciais dos parâmetros a partir dos valores médios obtidos para cada grupo. Os valores iniciais adotados para os parâmetros são apresentados na Tabela 4 do item Material e Métodos.

As curvas obtidas para os três grupos são mostradas a seguir:

$$
\begin{aligned}
& \text { Grupo } 1 \rightarrow Y=6,258-0,018^{\star}(29,999-\text { ID })+0,028^{*}(I D-29,999) \\
& \text { Grupo } 2 \rightarrow Y=6,896+0,033^{\star}(22,845-\text { ID })+0,020^{*}(I D-22,845) \\
& \text { Grupo } 3 \rightarrow Y=7,135+0,096^{*}(20,358-\text { ID })+0,016^{*}(\text { ID }-20,358)
\end{aligned}
$$


Os valores de PT sérica preditos pelas curvas para os trếs grupos nas diferentes idades são apresentados na Tabela 8 e ilustrados na Figura 2.

Tabela 8. Valores médios preditos da concentração de proteína total sérica $(\mathrm{g} / 100 \mathrm{~mL})$ nos grupos experimentais.

\begin{tabular}{|c|c|c|c|c|c|}
\hline $\begin{array}{l}\text { Idade } \\
\text { (dias) }\end{array}$ & Grupo 1 & $\begin{array}{l}\text { Idade } \\
\text { (dias) }\end{array}$ & Grupo 2 & $\begin{array}{l}\text { Idade } \\
\text { (dias) }\end{array}$ & Grupo 3 \\
\hline 1 & 6,259 & 1 & 7,617 & 1 & 8,998 \\
\hline 5 & 6,259 & 5 & 7,485 & 5 & 8,613 \\
\hline 10 & 6,259 & 10 & 7,320 & 10 & 8,132 \\
\hline 15 & 6,259 & 15 & 7,155 & 15 & 7,651 \\
\hline 17 & 6,259 & 17 & 7,089 & 17 & 7,458 \\
\hline 20 & 6,259 & 20 & 6,990 & 20 & 7,169 \\
\hline 25 & 6,259 & $22,845^{\star}$ & 6,896 & $20,358^{*}$ & 7,135 \\
\hline $29,999^{*}$ & 6,259 & 25 & 6,956 & 25 & 7,211 \\
\hline 30 & 6,259 & 30 & 7,095 & 30 & 7,292 \\
\hline 35 & 6,398 & 35 & 7,233 & 35 & 7,373 \\
\hline 40 & 6,538 & 40 & 7,372 & 40 & 7,455 \\
\hline 45 & 6,678 & 45 & 7,511 & 45 & 7,536 \\
\hline 50 & 6,818 & 50 & 7,649 & 50 & 7,617 \\
\hline 60 & 7,098 & 60 & 7,927 & 60 & 7,780 \\
\hline
\end{tabular}

Grupo 1 nível baixo $=$ até $20 \mathrm{mg} / \mathrm{mL}$ de $\lg G$

Grupo 2 nivel médio = entre 20 e $30 \mathrm{mg} / \mathrm{mL}$ de $\lg G$

Grupo 3 nivel alto = acima de $30 \mathrm{mg} / \mathrm{mL}$ de $\lg G$

" Idade no ponto de concentração mínima (R) 


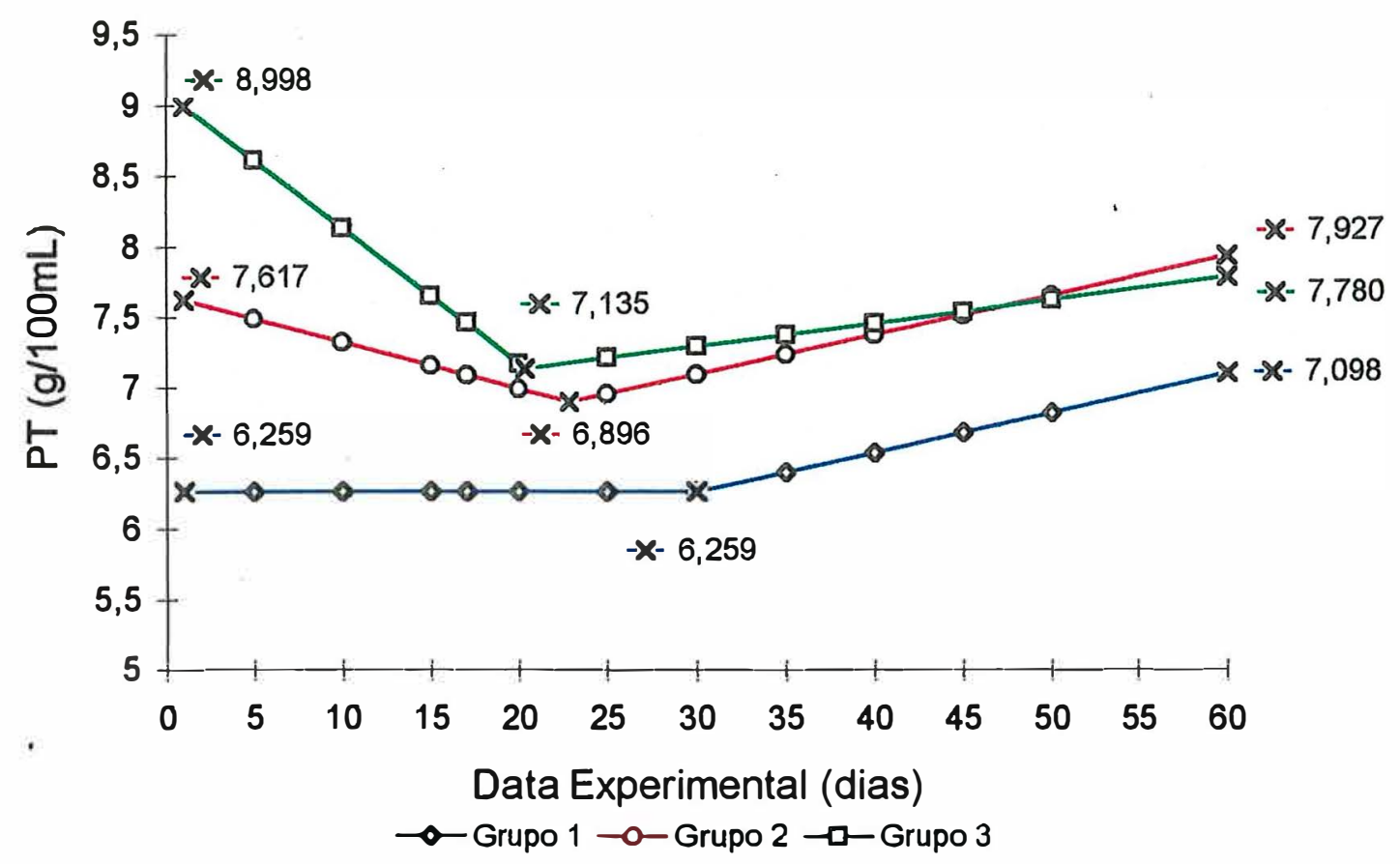

Figura 2. Flutuação da concentração média de proteína total $(\mathrm{g} / 100 \mathrm{~mL}) \mathrm{com}$ valores ajustados.

Para os grupos 2 e 3, houve um decréscimo na concentração de PT sérica no $1^{\circ}$ mês de vida, indicando um processo de catabolismo protéico, fato já observado por vários autores (Machado Neto \& Packer, 1986; Daniele et al., 1994b; Baracat et al., 1995; Bessi, 1996). O ponto de concentração mínimo de PT (L) para o grupo 2 foi $6,896 \mathrm{~g} / 100 \mathrm{~mL}$, dentro de um intervalo de confiança (IC) de 6,619 a 7,173 e para o grupo 3 , L foi $7,135 \mathrm{~g} / 100 \mathrm{~mL}$, em um intervalo de confiança de 6,880 a 7,389. A idade no ponto de concentração mínimo (R) para o grupo 2 foi igual a 22,845 dias, em um intervalo de confiança de 17,869 a 27,820 e para o grupo $3 \mathrm{R}$ foi igual a 20,358 dias, dentro de um intervalo de confiança de 16,609 a 24,106. A amplitude de variação dos valores de $L$ e $R$, expressa pelo IC, demonstrou que os grupos não diferiram entre si em 
relação a variável PT. Conclui-se, portanto, que houve um comportamento semelhante da flutuação de PT sérica ao longo do período experimental para os grupos 2 e 3.

Para $\circ$ grupo 1, ○ parâmetro $U$ apresentou intervalo de confiança que abrangia o valor zero, tornando-o não significativo, o que impossibilitou a determinação do ponto de concentração mínimo de PT. Isso sugere um comportamento crescente da variável em todo período experimental, consequência da síntese compensatória em função da baixa concentração sérica inicial de anticorpos. Na Figura 1 é detectada uma pequena queda, mas não significativa $(p<0,1269)$, na concentração sérica de PT por volta do $15^{\circ}$ dia de idade em relação a data experimental anterior, seguida por posterior aumento no restante do período experimental.

De acordo com os dados, quanto mais alto o valor inicial da $\mathrm{lg}$ sérica mais longo tende a ser $\circ$ período de catabolismo protéico e, consequentemente, a inflexão da curva, pois as imunoglobulinas adquiridas passivamente do colostro são as principais determinantes na variação de PT sérica no início da vida dos animais.

\subsection{Imunoglobulinas Séricas}

Os niveis médios de imunoglobulinas séricas, distribuídos nos três grupos definidos com base na concentração de lgG inicial, nas diferentes idades, são apresentados na Tabela 9 e a flutuação dessa variável é mostrada na Figura 3. Os dados originais de lgG sérica são apresentados nas Tabelas 6 , 7 , e 8 do Apêndice.

Através da análise de variância para o delineamento experimental em parcelas subdivididas, observou-se que houve diferença significativa na 
concentração sérica média de IgG entre os grupos $(p<0,0001)$, entre as idades experimentais $(p<0,0001)$ e foi também significativa a interação entre grupo e período ( $p<0,0001$ ), indicando diferença de comportamento na flutuação de IgG sérica entre os grupos ao longo do período experimental.

Tabela 9. Concentração média de $\lg G$ sérica $(\mathrm{mg} / \mathrm{mL})$ nos grupos experimentais.

\begin{tabular}{cccc}
\hline $\begin{array}{c}\text { Idade } \\
\text { (dias) }\end{array}$ & $\begin{array}{c}\text { Grupo 1 } \\
\text { Média } \pm \text { DP }\end{array}$ & $\begin{array}{c}\text { Grupo 2 } \\
\text { Média } \pm \text { DP }\end{array}$ & $\begin{array}{c}\text { Grupo 3 } \\
\text { Média } \pm \text { DP }\end{array}$ \\
\hline $\mathbf{1}$ & $7,70 \pm 1,45$ & $25,81 \pm 0,65$ & $39,62 \pm 1,68$ \\
$\mathbf{5}$ & $11,55 \pm 1,95$ & $25,27 \pm 1,72$ & $33,79 \pm 2,15$ \\
$\mathbf{1 0}$ & $11,29 \pm 1,87$ & $22,93 \pm 1,50$ & $31,20 \pm 2,37$ \\
$\mathbf{1 5}$ & $9,77 \pm 1,38$ & $20,70 \pm 1,04$ & $27,05 \pm 2,42$ \\
$\mathbf{1 7}$ & $9,42 \pm 1,30$ & $18,95 \pm 1,16$ & $26,36 \pm 2,13$ \\
$\mathbf{2 0}$ & $10,04 \pm 1,20$ & $18,44 \pm 1,18$ & $24,45 \pm 2,26$ \\
$\mathbf{2 5}$ & $12,35 \pm 1,12$ & $18,45 \pm 0,97$ & $22,46 \pm 1,77$ \\
$\mathbf{3 0}$ & $12,33 \pm 1,10$ & $18,49 \pm 1,23$ & $21,57 \pm 1,50$ \\
$\mathbf{3 5}$ & $15,26 \pm 1,29$ & $19,62 \pm 1,34$ & $20,39 \pm 1,39$ \\
$\mathbf{4 0}$ & $16,73 \pm 1,40$ & $20,83 \pm 1,22$ & $20,39 \pm 1,34$ \\
$\mathbf{4 5}$ & $17,91 \pm 1,92$ & $22,66 \pm 1,65$ & $21,81 \pm 2,21$ \\
$\mathbf{5 0}$ & $21,11 \pm 1,87$ & $23,14 \pm 1,75$ & $21,60 \pm 2,00$ \\
$\mathbf{6 0}$ & $20,59 \pm 1,61$ & $25,00 \pm 1,87$ & $22,73 \pm 2,21$ \\
\hline
\end{tabular}

Grupo 1 nível baixo = até $20 \mathrm{mg} / \mathrm{mL}$ de $\mathrm{lgG}$

Grupo 2 nível médio = entre 20 e $30 \mathrm{mg} / \mathrm{mL}$ de $\mathrm{lgG}$

Grupo 3 nivel alto $=$ acima de $30 \mathrm{mg} / \mathrm{mL}$ de $\mathrm{lgG}$

$\mathrm{DP}=$ Desvio Padrão 


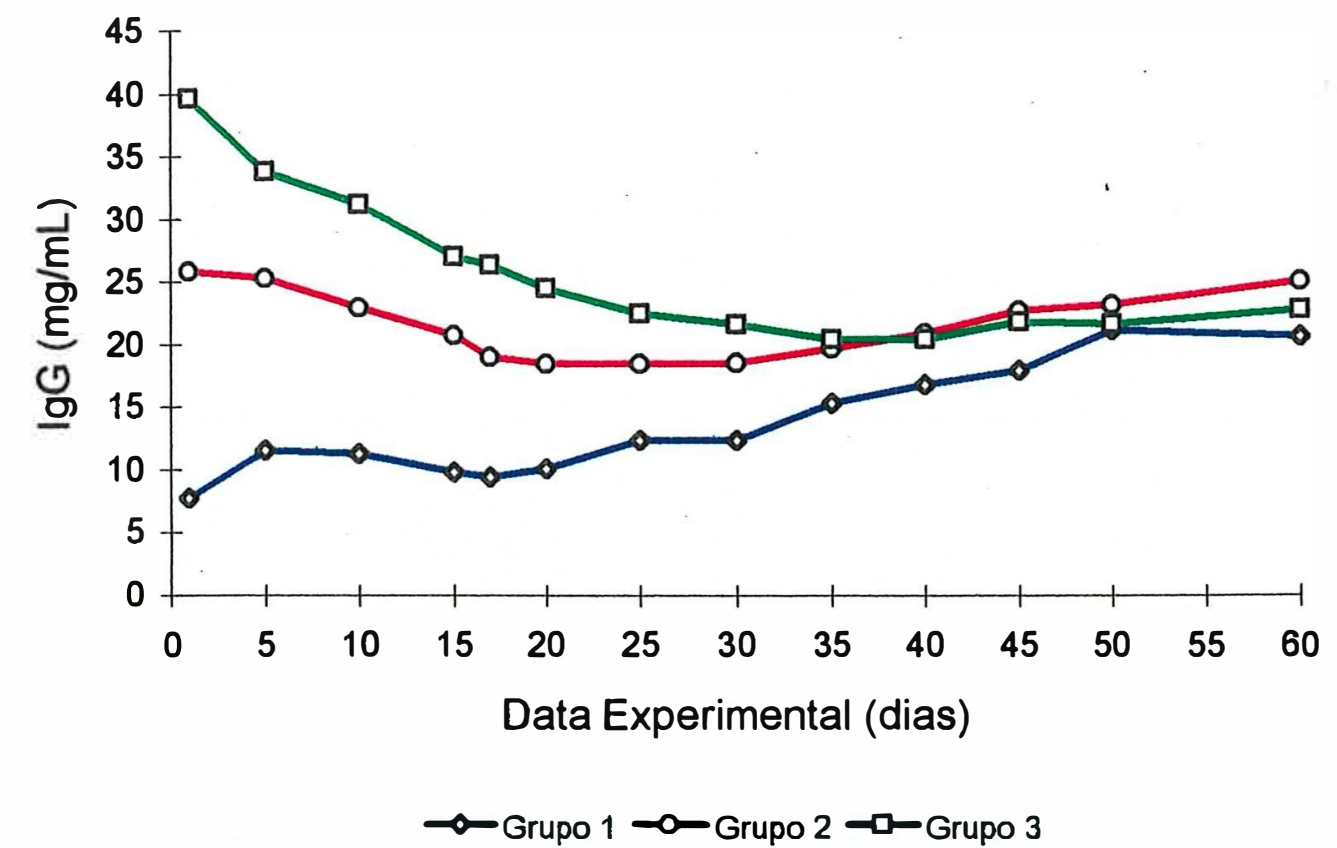

Figura 3. Flutuação da concentração média de $\lg G$ sérica $(\mathrm{mg} / \mathrm{mL})$ nos grupos experimentais.

Em função do agrupamento, os valores de IgG sérica diferiram significativamente entre os grupos na data inicial $(p<0,0001)$. As médias de lgG sérica $(\mathrm{mg} / \mathrm{mL})$ no $1^{\circ}$ dia foram $7,70 \pm 1,45$ para o grupo $1 ; 25,81 \pm 0,65$ para 0 grupo 2 e 39,62 $\pm 1,68$ para o grupo 3 . As diferenças observadas na concentração inicial de lg nos animais podem ser atribuídas a fatores relacionados ao colostro, ao animal e ao manejo (Edwards et al., 1982; Robison et al., 1988).

Para os valores de IgG sérica, foi observada diferença significativa entre os grupos 1 e 2 e 1 e 3 até 45 dias de idade. As médias de IgG sérica $(\mathrm{mg} / \mathrm{mL})$ aos 45 dias foram $17,91 \pm 1,92$ para $\circ$ grupo $1 ; 22,66 \pm 1,65$ para 0 grupo 2 e $21,81 \pm 2,21$ para o grupo 3 . Entre os grupos 2 e 3 houve diferença 
significativa até os 25 dias de idade, com médias de lgG sérica $(\mathrm{mg} / \mathrm{mL})$ de $18,45 \pm 0,97$ para o grupo 2 e $22,46 \pm 1,77$ para $\circ$ grupo 3 . As probabilidades encontradas na comparação entre os grupos encontram-se na Tabela 18 do Apêndice.

Vários autores relataram a ocorrência do valor máximo de Imunoglobulinas séricas entre 24 e 48 horas de vida (Klaus et al., 1969; Husband et al., 1972; Logan et al., 1978; Ribeiro et al., 1983; Machado Neto \& Packer, 1986). Essa afirmação está de acordo com os resultados obtidos para os grupos 2 e 3 . No caso dos animais pertencentes ao grupo 1, agrupados com valores de IgG sérica inicial abaixo de $20 \mathrm{mg} / \mathrm{mL}$, verificou-se falha de transferência de imunidade passiva. De acordo com Ribeiro et al. (1983), animais são considerados hipogamaglobulinêmicos quando a concentração sérica, após o período inicial de aquisição (24 horas), for menor que $10 \mathrm{mg} / \mathrm{mL}$. Assim, para $\circ$ grupo 1, a média de IgG sérica às 24 horas foi de $7,70 \pm 1,45$ $\mathrm{mg} / \mathrm{mL}$. Esses animais apresentaram pequeno aumento da concentração sérica de IgG $(p<0,0203)$ entre $\circ 1^{\circ}$ e $\circ 10^{\circ}$ dia de idade com concentração média de $11,29 \pm 1,87 \mathrm{mg} / \mathrm{mL}$, sofrendo pequena queda, não significativa $(p<0,1591)$, até - $17^{\circ}$ dia, seguida de aumento até o final do período experimental. Esse comportamento reflete o processo de anabolismo precoce que os animais com baixas concentrações iniciais apresentam.

Já os animais pertencentes aos grupos 2 e 3 apresentaram níveis de IgG séricas iniciais acima dos níveis considerados adequados, refletindo o sucesso na ingestão da primeira refeição.

Assim, como ocorre para as imunoglobulinas, a proteína sérica em bezerros, a partir do nascimento, segue um padrão de variação semelhante. Ao nascer 0 animal apresenta níveis baixos de PT sérica que aumentam após a 
ingestão do colostro atingindo pico de concentração em média no $5^{\circ}$ dia de vida, decrescendo gradativamente e atingindo a estabilidade. $O$ fato da concentração sérica de PT decrescer no $1^{0}$ mês de vida já foi relatado por vários autores, sendo essa queda reflexo do catabolismo de anticorpos adquiridos do colostro sobre o conjunto das proteínas séricas (Tennant et al., 1969; Husband et al., 1972; Fagliari et al., 1983, Nocek et., 1984; Machado Neto \& Packer, 1986).

A concentração inicial máxima de PT sérica foi verificada no $10^{\circ}$ dia para o grupo $1(6,25 \pm 0,18 \mathrm{~g} / 100 \mathrm{~mL})$, no $5^{\circ}$ dia para o grupo $2(7,62 \pm 0,36$ $\mathrm{g} / 100 \mathrm{~mL})$ e no $1^{\circ}$ dia para o grupo $3(9,17 \pm 0,23 \mathrm{~g} / 100 \mathrm{~mL})$, mais uma vez refletindo a influência da concentração sérica de lgG sobre PT nos primeiros dias de vida.

Os valores mínimos médios calculados para a variável PT sérica foram $5,11 \pm 0,66 \mathrm{~g} / 100 \mathrm{~mL}$ para $\circ$ grupo $1 ; 6,64 \pm 0,75 \mathrm{~g} / 100 \mathrm{~mL}$ para $\circ$ grupo 2 e $6,61 \pm 0,72 \mathrm{~g} / 100 \mathrm{~mL}$ para o grupo 3 . Pelo teste de Tukey, verificou-se que não houve diferença significativa entre os grupos 2 e 3 para a concentração mínima, mas a médias entre os grupos 1 e 2 e 1 e 3 diferiram significativamente $(p<0,05)$. A data de ocorrência dos valores mínimos foi 10,46 $\pm 13,43$ dias para o grupo $1 ; 21,53 \pm 11,68$ dias para o grupo 2 e 27,28 \pm 10,64 dias para o grupo 3. Como ocorreu com a concentração mínima de PT, os grupos apresentaram o mesmo comportamento para a data de ocorrência dos valores mínimos. Observou-se que os animais pertencentes aos grupos 2 e 3 possuem uma queda mais prolongada dos valores de PT sérica em relação ao grupo 1 . 0 ponto de concentração mínima para PT reflete a transição entre a fase de catabolismo das imunoglobulinas exógenas e o início da produção endógena da fração lgG e outras classes de imunoglobulinas. 
Foram calculadas, também, as concentrações mínimas de $\lg G$ e as datas de ocorrência desses valores. As concentrações mínimas médias foram $4,67 \pm 4,71 \mathrm{mg} / \mathrm{mL}$ para o grupo $1 ; 16,31 \pm 3,39 \mathrm{mg} / \mathrm{mL}$ para o grupo 2 e $16,57 \pm 5,07 \mathrm{mg} / \mathrm{mL}$ para o grupo 3 . Pelo teste de Tukey verificou-se que não houve diferença significativa entre os grupos 2 e 3 para a concentração mínima, mas as médias entre os grupos 1 e 2 e 1 e 3 diferiram significativamente $(p<0,05)$. As datas de ocorrência desses valores foram 11,19 $\pm 12,69$ dias para o grupo 1; 28,27 $\pm 12,66$ dias para o grupo 2 e 34,67 $\pm 14,64$ dias para grupo 3 . As datas de ocorrência do ponto mínimo entre os grupos 2 e 3 também não diferiram, sendo encontrada diferença significativa entre os grupos 1 e 2 e 1 e 3 $(p<0,05)$. Baracat et al. (1995) também observaram que a data de ocorrência do ponto de concentração mínima para PT ocorreu mais precocemente do que o ponto de concentração mínimo para lgG. A flutuação da proteina total sérica nesse período se deve a outras proteínas séricas, além de lgG e a produção de outras classes de imunoglobulinas.

Como ocorreu em trabalhos realizados por outros autores, após 0 ponto de menor concentração ser atingido verifica-se um aumento da concentração de lgG sérica devido a produção endógena (Machado Neto \& Packer, 1986; Bessi 1996). A flutuação das imunoglobulinas séricas é resultado do catabolismo de anticorpos adquiridos passivamente, da migração de anticorpos séricos para a luz do intestino e início da produção endógena, condição que é acentuada a partir do $20^{\circ}$ dia de idade (Husband et al., 1972; Machado Neto \& Packer, 1986).

Como na variável PT, foram usadas regressões não-lineares para explicar o comportamento da variável IgG ao longo do periodo experimental. Foram obtidas curvas para os três grupos de acordo com o mesmo modelo 
aplicado para a variável PT. Não foram encontrados valores iniciais dos parâmetros disponiveis em literatura, sendo os mesmos escolhidos a partir dos valores médios obtidos para cada grupo. Os valores iniciais adotados para os parâmetros são apresentados na Tabela 5 do item Material e Métodos.

Para cada grupo foram obtidas as seguintes equações segmentadas:

$$
\begin{aligned}
& \text { Grupo } 1 \rightarrow Y=10,321-0,035^{\star}(19,592-\text { ID })+0,294^{\star}(I D-19,592) \\
& \text { Grupo } 2 \rightarrow Y=17,376+0,424^{\star}(22,290-\text { ID })+0,294^{\star}(I D-22,290) \\
& \text { Grupo } 3 \rightarrow Y=20,438+0,695^{\star}(26,019-\text { ID })+0,056^{\star}(I D-26,019)
\end{aligned}
$$

Os valores médios de Ig sérica preditos pelas curvas nas diferentes idades são apresentados na Tabela 10 e ilustrados na Figura 4.

A queda na concentração de $\lg G$ no primeiro mês de vida para os grupos 2 e 3 foi resultado do catabolismo dessas proteínas adquiridas passivamente do colostro. A idade no ponto de concentração mínima (R) foi 22,290 dias; em um intervalo de confiança (IC) de 19,327 a 25,252 para o grupo 2 , e para o grupo $3 R$ foi igual a 26,019 dias; dentro de um intervalo de confiança de 20,771 a 31,267, demonstrando que os grupos não diferiram entre si quanto a idade no ponto de concentração mínima para a variável lgG. 
Tabela 10. Valores médios preditos da concentração de imunoglobulinas $(\mathrm{mg} / \mathrm{mL})$ nos grupos experimentais.

\begin{tabular}{cccccc}
\hline $\begin{array}{c}\text { Idade } \\
\text { (dias) }\end{array}$ & Grupo 1 & $\begin{array}{c}\text { Idade } \\
\text { (dias) }\end{array}$ & Grupo 2 & $\begin{array}{c}\text { Idade } \\
\text { (dias) }\end{array}$ & Grupo 3 \\
\hline 1 & 10,321 & 1 & 26,403 & 1 & 37,819 \\
5 & 10,321 & 5 & 24,707 & 5 & 35,041 \\
10 & 10,321 & 10 & 22,587 & 10 & 31,567 \\
15 & 10,321 & 15 & 20,467 & 15 & 28,093 \\
17 & 10,321 & 17 & 19,619 & 17 & 26,704 \\
\hline $19,592^{*}$ & 10,321 & 20 & 18,347 & 20 & 24,620 \\
\hline 20 & 10,441 & $22,290^{*}$ & 17,376 & 25 & 21,146 \\
25 & 11,914 & 25 & 17,934 & $26,019^{*}$ & 20,438 \\
\cline { 3 - 5 } 30 & 13,387 & 30 & 18,963 & 30 & 20,438 \\
35 & 14,860 & 35 & 19,992 & 35 & 20,438 \\
40 & 16,333 & 40 & 21,021 & 40 & 20,438 \\
45 & 17,807 & 45 & 22,049 & 45 & 20,438 \\
50 & 19,280 & 50 & 23,078 & 50 & 20,438 \\
60 & 22,226 & 60 & 25,136 & 60 & 20,438 \\
\hline
\end{tabular}

Grupo 1 nível baixo = até $20 \mathrm{mg} / \mathrm{mL}$ de $\lg G$

Grupo 2 nível médio = entre 20 e $30 \mathrm{mg} / \mathrm{mL}$ de $\lg G$

Grupo 3 nível alto $=$ acima de $30 \mathrm{mg} / \mathrm{mL}$ de $\lg G$

*Idade no ponto de concentração mínima (R) 


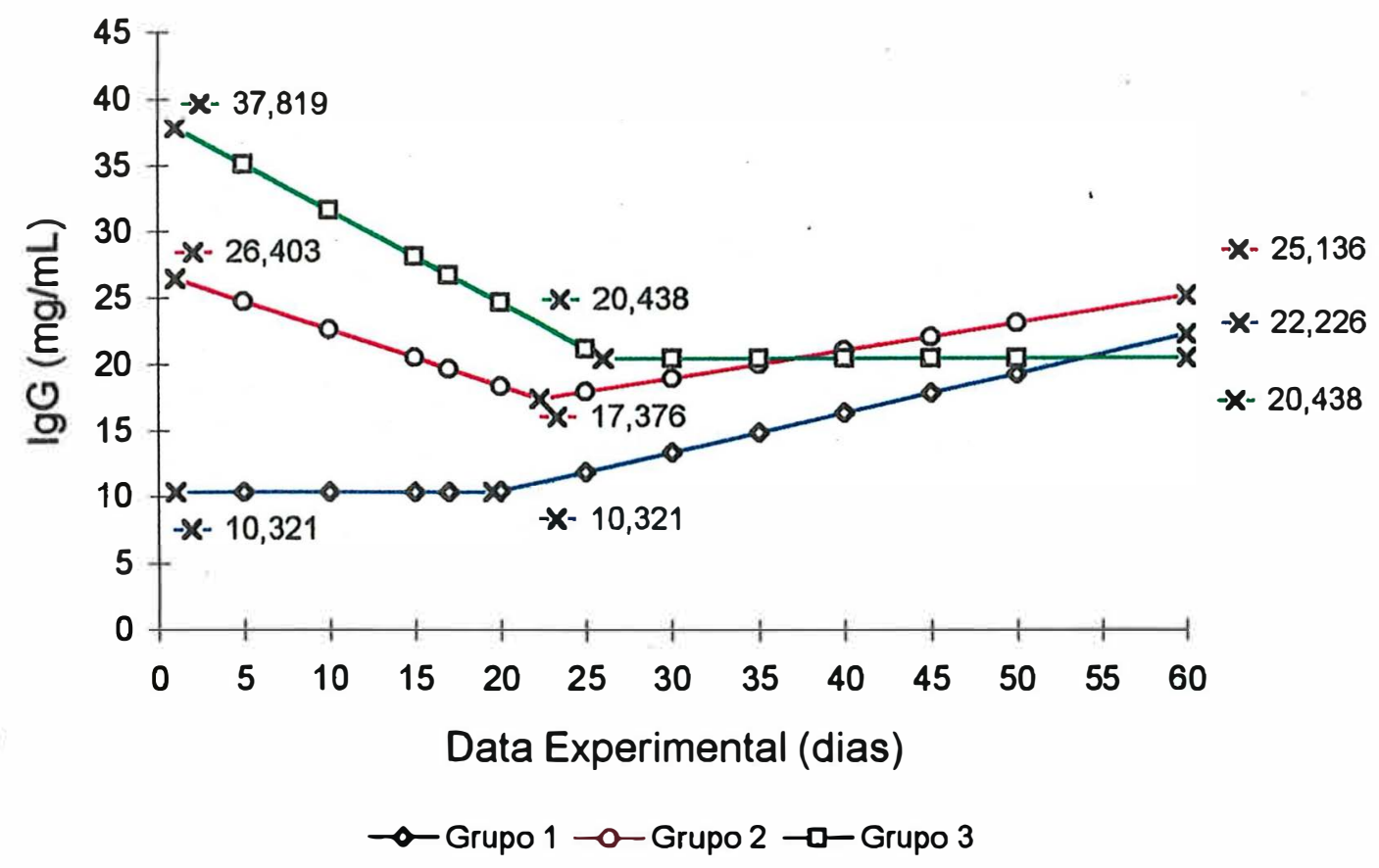

Figura 4. Flutuação da concentração média de $\operatorname{lgG}$ sérica $(\mathrm{mg} / \mathrm{mL})$ com valores ajustados.

Para o grupo 3 o coeficiente angular no período posterior ao ponto de concentração mínima (V) apresentou intervalo de confiança que abrangia o valor zero, tornando o parâmetro não significativo. Esșe resultado indica a ocorrência de um platô entre data de concentração mínima $R=26,019$ e o término do período experimental aos 60 dias. Esse fato é consequência da alta concentração inicial de imunoglobulinas adquiridas, como já discutido anteriormente, retardando a produção endógena de anticorpos. Nos dados originais detecta-se um pequeno aumento na concentração sérica de lgG, mas não significativo $(p<0,4631)$, por volta do $45^{\circ}$ dia de idade em relação a data experimental anterior, o que não foi verificado na equação que ajusta os valores observados. Daniele et al. (1994a), trabalhando com animais com altos níveis 
de imunoglobulinas séricas iniciais, verificaram, também, prolongado periodo de declínio na concentração sérica de lgG entre 40 e 60 dias de idade.

Já para o grupo 1, o coeficiente angular no período anterior ao ponto de concentração mínima $(U)$ apresentou intervalo de confiança que abrangia o valor zero, tornando-o não significativo. Verifica-se, assim, comportamento semelhante da variável IgG em relação a variável PT para a qual também não foi observado ponto de concentração mínima. Portanto, para o grupo 1, não se observou o pico inicial de lgG seguido de queda, fato que pode ser justificado pela própria condição inicial que determinou uma reduzida atividade de catabolismo e uma precocidade da produção endógena de anticorpos.

Observando-se os dados médios de lg sérica, os quais não apresentam mais diferença significativa entre os grupos a partir de 45 dias de idade, observou-se que para o grupo 1 com concentração média inicial de 7,70 $\mathrm{mg} / \mathrm{mL}$, houve um acréscimo na concentração sérica de $\mathrm{lg} G$ de $10,21 \mathrm{mg} / \mathrm{mL}$ do nascimento até 45 dias de idade. Essa condição encontrada no grupo 1 explica a ausência de pico inicial seguido por uma fase catabólica, pois a síntese de anticorpos se estabelece desde os primeiros dias de vida. Para o grupo $3 \mathrm{com}$ concentração média inicial de $39,62 \mathrm{mg} / \mathrm{mL}$, houve um decréscimo até essa data de $17,81 \mathrm{mg} / \mathrm{mL}$, e para $\circ$ grupo 2 com concentração média inicial de $25,81 \mathrm{mg} / \mathrm{mL}$ houve a menor variação nesse periodo, apresentando um decréscimo de $3,15 \mathrm{mg} / \mathrm{mL}$. As variações nas concentrações dos grupos podem ser observadas na Tabela 11. 
Tabela 11. Variações nas concentrações séricas de $\lg G(\mathrm{mg} / \mathrm{mL})$ nos grupos experimentais.

\begin{tabular}{|c|c|c|c|}
\hline $\begin{array}{l}\text { Idade } \\
\text { (dias) }\end{array}$ & $\begin{array}{c}\text { Grupo } 1 \\
\text { Média } \pm \text { DP }\end{array}$ & $\begin{array}{c}\text { Grupo } 2 \\
\text { Média } \pm \text { DP }\end{array}$ & $\begin{array}{c}\text { Grupo } 3 \\
\text { Média } \pm \text { DP }\end{array}$ \\
\hline$\overline{1}$ & $7,70 \pm 1,45$ & $25,81 \pm 0,65$ & $\overline{39,62 \pm 1,68}$ \\
\hline 5 & $11,55 \pm 1,95$ & $25,27 \pm 1,72$ & $33,79 \pm 2,15$ \\
\hline 10 & $11,29 \pm 1,87$ & $22,93 \pm 1,50$ & $31,20 \pm 2,37$ \\
\hline 15 & $9,77 \pm 1,38$ & $20,70 \pm 1,04$ & $27,05 \pm 2,42$ \\
\hline 17 & $+10,21 * 9,42 \pm 1,30$ & $-3,15^{*} 18,95 \pm 1,16$ & $-17,81 \cdot 26,36 \pm 2,13$ \\
\hline 20 & $10,04 \pm 1,20$ & $18,44 \pm 1,18$ & $24,45 \pm 2,26$ \\
\hline 25 & $12,35 \pm 1,12$ & $18,45 \pm 0,97$ & $22,46 \pm 1,77$ \\
\hline 30 & $12,33 \pm 1,10$ & $18,49 \pm 1,23$ & $21,57 \pm 1,50$ \\
\hline 35 & $15,26 \pm 1,29$ & $19,62 \pm 1,34$ & $20,39 \pm 1,39$ \\
\hline 40 & $16,73 \pm 1,40$ & $20,83 \pm 1,22$ & $20,39 \pm 1,34$ \\
\hline 45 & $17,91 \pm 1,92$ & $22,66 \pm 1,65$ & $21,81 \pm 2,21$ \\
\hline 50 & $21,11 \pm 1,87$ & $23,14 \pm 1,75$ & $21,60 \pm 2,00$ \\
\hline 60 & $20,59 \pm 1,61$ & $25,00 \pm 1,87$ & $22,73 \pm 2,21$ \\
\hline
\end{tabular}

Grupo 1 nivel baixo $=$ até $20 \mathrm{mg} / \mathrm{mL}$ de $\lg G$

Grupo 2 nivel médio = entre 20 e $30 \mathrm{mg} / \mathrm{mL}$ de $\lg G$

Grupo 3 nivel alto $=$ acima de $30 \mathrm{mg} / \mathrm{mL}$ de $\mathrm{IgG}$

DP= Desvio Padrão

*Diferença na concentração sérica de lgG $(\mathrm{mg} / \mathrm{mL})$ entre $\circ 1^{\circ}$ e o $45^{\circ}$ dia

Portanto, o comportamento geral da flutuação de lg mostra claramente uma tendência de estabilidade ao final do período experimental, em torno do valor $20-25 \mathrm{mg} / \mathrm{mL}$ para os três grupos. Essa estabilidade se dá as custas da redução dos valores mais altos e elevação dos valores mais baixos, sendo que $\circ$ grupo médio inicia e termina o período experimental com valores semelhantes $(p<0,4490)$. 
Com esses resultados, verifica-se que as flutuações ocorrem em direção a concentrações fisiologicamente desejáveis e pré-determinadas, isto é em torno de 20 - $25 \mathrm{mg} \mathrm{lg} / \mathrm{mL}$. Esse valor fisiológico, encontrado por volta dos 60 dias de idade também foi verificado em outros trabalhos com diferentes niveis inicias de imunidade passiva em bezerros leiteiros (Daniele et al., 1994a; Bessi, 1996; Baracat et al., 1997). McGuire et al. (1976), trabalhando com bezerros de corte, encontraram resultados semelhantes. Os autores observaram que a ampla variação na concentração de lgG sérica, encontrada nos animais nas primeiras semanas de vida, havia desaparecido aos dois meses de idade, quando animais com altas ou baixas concentrações iniciais atingiram valores similares, 0 que sugere que as taxas de catabolismo e anabolismo seriam parecidas, resultando em uma concentração sérica uniforme. Baracat et al. (1997), trabalhando com animais com duas condições de imunidade passiva adquirida, grupo alto $(46,89 \pm 7,3 \mathrm{mg} / \mathrm{mL})$ e grupo baixo (25,58 $\pm 7,7 \mathrm{mg} / \mathrm{mL})$, observaram que a superioridade na média de lgG dos bezerros do grupo alto, em relação ao baixo, manteve-se durante os 60 dias estudados. Os autores sugeriram que esse comportamento das imunoglobulinas seria consequência de uma taxa de catabolismo constante dos anticorpos adquiridos passivamente, independentemente da concentração das mesmas.

\subsection{Desempenho}

Os dados médios de peso dos animais nas diferentes idades são apresentados na Tabela 12 e ilustrados na Figura 5. Os dados originais são apresentados nas Tabelas 9,10 e 11 do Apêndice.

Através da análise de variância e da covariância para experimentos em parcelas subdivididas, verificou-se que 0 peso inicial 
influenciou $o$ peso final dos animais $(p<0,0001)$, sendo utilizado como covariável para a análise dos dados. Por outro lado, lgG sérica inicial (1 dia) não influenciou o peso final aos 60 dias de idade, não sendo considerada nessa análise como covariável.

Tabela 12. Pesos médios $(\mathrm{kg})$ por grupo, no período de 1 a 60 dias de idade.

\begin{tabular}{cccc}
\hline $\begin{array}{c}\text { Idade } \\
\text { (dias) }\end{array}$ & $\begin{array}{c}\text { Grupo 1 } \\
\text { Média } \pm \text { DP }\end{array}$ & $\begin{array}{c}\text { Grupo 2 } \\
\text { Média } \pm \text { DP }\end{array}$ & $\begin{array}{c}\text { Grupo 3 } \\
\text { Média } \pm \text { DP }\end{array}$ \\
\hline 1 & $35,39 \pm 1,71$ & $38,21 \pm 0,99$ & $38,62 \pm 1,84$ \\
5 & $37,34 \pm 1,75$ & $38,89 \pm 0,79$ & $39,84 \pm 1,93$ \\
10 & $40,24 \pm 1,88$ & $39,4 \pm 0,79$ & $40,68 \pm 1,80$ \\
15 & $42,33 \pm 1,97$ & $40,83 \pm 0,93$ & $42,15 \pm 1,75$ \\
17 & $43,08 \pm 1,99$ & $41,8 \pm 0,83$ & $43,46 \pm 1,93$ \\
20 & $45,06 \pm 2,05$ & $42,88 \pm 0,98$ & $43,84 \pm 1,83$ \\
25 & $47,56 \pm 1,98$ & $44,81 \pm 1,01$ & $46,00 \pm 1,90$ \\
30 & $49,72 \pm 2,06$ & $47,20 \pm 0,98$ & $47,03 \pm 1,93$ \\
35 & $52,47 \pm 2,33$ & $48,94 \pm 0,93$ & $49,79 \pm 2,03$ \\
40 & $55,35 \pm 2,53$ & $50,98 \pm 1,10$ & $52,00 \pm 2,35$ \\
45 & $57,77 \pm 2,39$ & $54,21 \pm 1,20$ & $55,01 \pm 2,37$ \\
50 & $60,83 \pm 5,50$ & $55,99 \pm 1,58$ & $57,69 \pm 2,59$ \\
60 & $65,90 \pm 2,87$ & $62,51 \pm 1,79$ & $63,86 \pm 2,89$ \\
\hline
\end{tabular}

Grupo 1 nivel baixo = até $20 \mathrm{mg} / \mathrm{mL}$ de $\operatorname{lgG}$

Grupo 2 nivel médio $=$ entre 20 e $30 \mathrm{mg} / \mathrm{mL}$ de $\lg G$

Grupo 3 nivel alto $=$ acima de $30 \mathrm{mg} / \mathrm{mL}$ de $\lg G$

DP= Desvio Padrão 


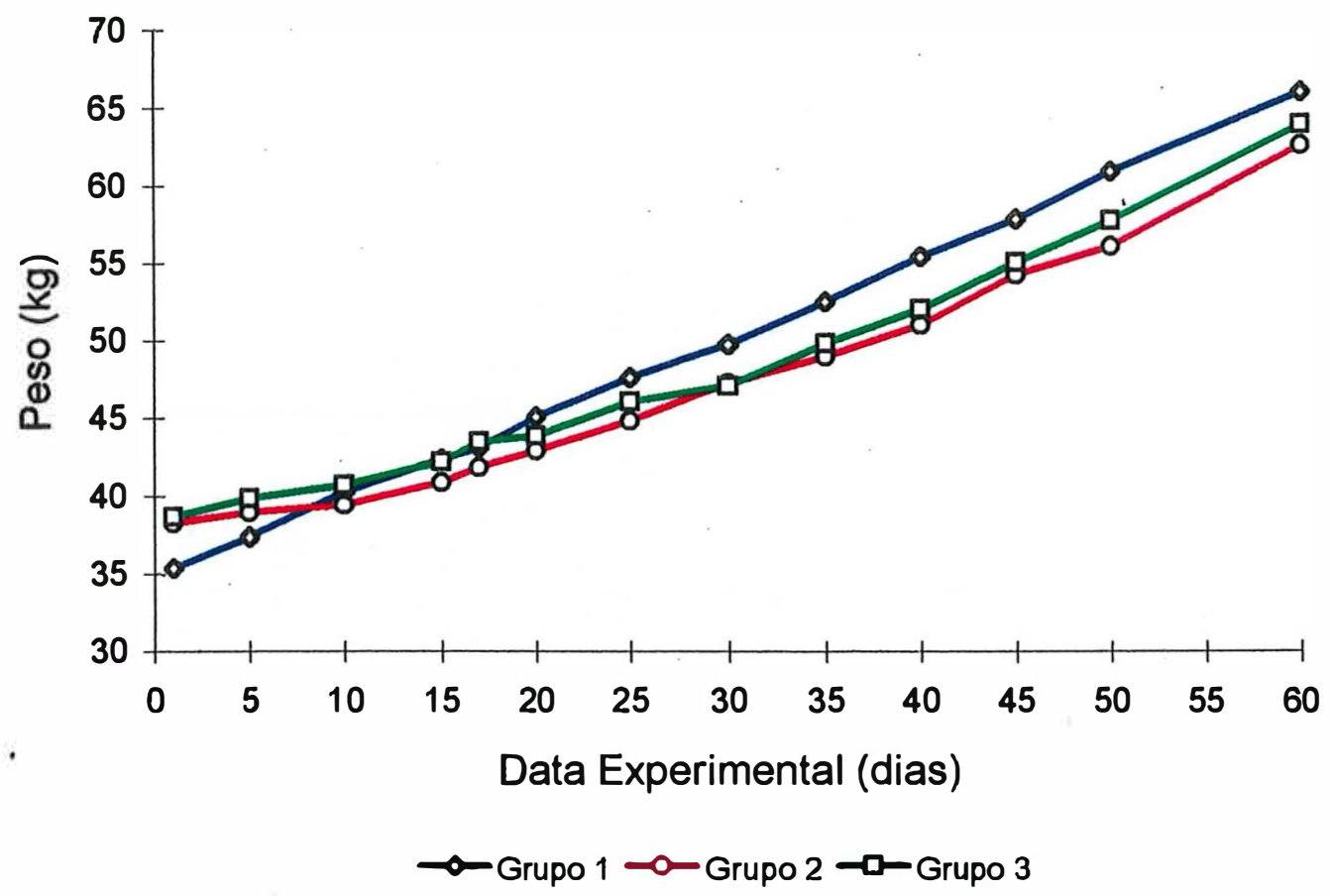

Figura 5. Pesos médios observados nos grupos experimentais no período de 1 a 60 dias de idade.

Os pesos dos animais aos 60 dias foram ajustados para peso inicial e comparados por teste de Tukey. Verificou-se que o peso final não diferiu entre os 3 grupos, com médias ajustadas para peso inicial de $67,70 \pm$ $1,97 \mathrm{~kg}$ para o grupo $1 ; 61,04 \pm 2,64 \mathrm{~kg}$ para o grupo 2 e $62,40 \pm 2,36 \mathrm{~kg}$ para $\circ$ grupo 3.

A seguir, na Tabela 13, são apresentados os ganhos médios de peso por grupo. Os ganhos de peso totais para cada animal nos três grupos são apresentados nas Tabela 16 do Apêndice.

As médias de ganho de peso para os três grupos para todo o período experimental foram $30,14 \pm 4,26 \mathrm{~kg}$ para o grupo $1 ; 22,33 \pm 2,14 \mathrm{~kg}$ 
para $\circ$ grupo 2 e 21,71 $\pm 1,87 \mathrm{~kg}$ para $\circ$ grupo 3 . Através do teste de Tukey observou-se que o ganho de peso entre os três grupos não diferiu.

Pelas análises de variância e covariância houve somente uma tendência $(p<0,0833)$ dos grupos em diferir no ganho de peso médio no total do período, sendo que o peso inicial não influiu no ganho de peso total. Da mesma maneira, a concentração de IgG sérica no $1^{0}$ dia de idade não influenciou 0 ganho de peso médio total, fato também observado por Edwards et al. (1982); Nocek et al. (1984); Lopez (1988); Zanetti (1990).

Não houve diferença significativa entre os grupos para ganho de peso médio até 50 dias de idade. Já para o período entre 50 e 60 dias, o grupo 2 foi superior ao grupo $1(p<0,0105)$ e houve uma tendência de superioridade em relação ao grupo 3 ( $p<0,0855)$, com médias de ganhos de peso para o período de 5,30 $\pm 0,88 \mathrm{~kg}$ para $\circ$ grupo $1,7,56 \pm 0,80 \mathrm{~kg}$ para $\circ$ grupo 2 e 5,92 $\pm 0,84$ para $\circ$ grupo 3 . As probabilidades encontradas para a comparação entre os grupos nas datas experimentais encontram-se na Tabela 19 do Apêndice.

A diferença encontrada entre os grupos no período está relacionada ao maior consumo de concentrado pelos animais, que ocorreu na fase final do período experimental entre 40 e 60 dias. Daniele (1993) também encontrou diferenças significativas no ganho de peso médio diário após 30 dias de idade, periodo em que os bezerros ganham peso mais rapidamente.

Os valores referentes ao consumo médio de concentrado $(\mathrm{g})$ nos três grupos são apresentados na Tabela 14 e ilustrados na Figura 6. Os dados originais são apresentados nas Tabelas 12, 13 e 14 do Apêndice. As análises de variância e covariância indicaram que os grupos não diferiram significativamente no período total $(p<0,1942)$, mas houve uma tendência de interação significativa entre grupo e período $(p<0,0879)$. O peso inicial, bem 
como IgG sérica no $1^{\circ}$ dia de idade, não influenciaram o consumo médio dos animais.

Tabela 13. Ganho de peso médio $(\mathrm{kg})$ dos grupos entre os períodos experimentais.

\begin{tabular}{cccc}
\hline $\begin{array}{c}\text { Idade } \\
\text { (dias) }\end{array}$ & $\begin{array}{c}\text { Grupo 1 } \\
\text { Média } \pm \text { DP }\end{array}$ & $\begin{array}{c}\text { Grupo 2 } \\
\text { Média } \pm \text { DP }\end{array}$ & $\begin{array}{c}\text { Grupo 3 } \\
\text { Média } \pm \text { DP }\end{array}$ \\
\hline 1 & - & - & - \\
5 & $1,95 \pm 0,52$ & $0,68 \pm 0,59$ & $1,21 \pm 0,55$ \\
10 & $2.90 \pm 0,49$ & $0,50 \pm 0,49$ & $0,84 \pm 0,49$ \\
15 & $2,10 \pm 0,43$ & $1,43 \pm 0,41$ & $1,47 \pm 0,39$ \\
17 & $0,72 \pm 0,37$ & $1,36 \pm 0,36$ & $1,11 \pm 0,48$ \\
20 & $1,98 \pm 0,65$ & $0,78 \pm 0,36$ & $0,64 \pm 0,39$ \\
25 & $2,50 \pm 0,42$ & $2,07 \pm 0,64$ & $2,05 \pm 0,37$ \\
30 & $2,10 \pm 0,60$ & $2,39 \pm 0,56$ & $1,12 \pm 0,64$ \\
35 & $2,67 \pm 0,54$ & $1,73 \pm 0,50$ & $2,76 \pm 0,59$ \\
40 & $2,88 \pm 0,63$ & $2,03 \pm 0,65$ & $2,21 \pm 0,79$ \\
45 & $2,42 \pm 0,43$ & $2,95 \pm 0,73$ & $3,01 \pm 0,53$ \\
50 & $3,05 \pm 0,50$ & $1,78 \pm 0,73$ & $2,67 \pm 0,67$ \\
60 & $5,30 \pm 0,88$ & $7,56 \pm 0,80$ & $5,92 \pm 0,84$ \\
\hline
\end{tabular}

Grupo 1 nível baixo = até $20 \mathrm{mg} / \mathrm{mL}$ de $\mathrm{lgG}$

Grupo 2 nível médio = entre 20 e $30 \mathrm{mg} / \mathrm{mL}$ de $\mathrm{lgG}$

Grupo 3 nivel alto = acima de $30 \mathrm{mg} / \mathrm{mL}$ de $\mathrm{lgG}$

$\mathrm{DP}=$ Desvio Padrão 
Tabela 14. Consumo médio de concentrado (g) por grupo, no período de 1 a 60 dias de idade.

\begin{tabular}{cccc}
\hline $\begin{array}{c}\text { Idade } \\
\text { (dias) }\end{array}$ & $\begin{array}{c}\text { Grupo 1 } \\
\text { Média } \pm \text { DP }\end{array}$ & $\begin{array}{c}\text { Grupo 2 } \\
\text { Média } \pm \text { DP }\end{array}$ & $\begin{array}{c}\text { Grupo 3 } \\
\text { Média } \pm \text { DP }\end{array}$ \\
\hline $\mathbf{5}$ & $0,00 \pm 0,00$ & $0,00 \pm 0,00$ & $0,00 \pm 0,00$ \\
10 & $88,46 \pm 24,07$ & $116,66 \pm 49,92$ & $110,28 \pm 35,94$ \\
15 & $255,19 \pm 36,58$ & $310,00 \pm 70,07$ & $236,11 \pm 46,93$ \\
$\mathbf{2 0}$ & $480,19 \pm 47,38$ & $660,00 \pm 149,30$ & $436,11 \pm 59,93$ \\
$\mathbf{2 5}$ & $769,42 \pm 55,64$ & $850,00 \pm 113,40$ & $717,65 \pm 77,05$ \\
$\mathbf{3 0}$ & $1363,46 \pm 126,26$ & $1332,14 \pm 164,22$ & $948,44 \pm 114,30$ \\
$\mathbf{3 5}$ & $1559,38 \pm 130,27$ & $1850,00 \pm 225,14$ & $1489,06 \pm 192,72$ \\
$\mathbf{4 0}$ & $2272,92 \pm 181,75$ & $2478,57 \pm 291,63$ & $1840,63 \pm 200,53$ \\
$\mathbf{4 5}$ & $2543,75 \pm 198,60$ & $3161,54 \pm 550,47$ & $2593,75 \pm 362,31$ \\
$\mathbf{5 0}$ & $3068,75 \pm 287,11$ & $3439,62 \pm 316,59$ & $3193,75 \pm 434,71$ \\
$\mathbf{6 0}$ & $5561,36 \pm 545,82$ & $7708,33 \pm 1072,61$ & $6357,14 \pm 1012,68$ \\
\hline
\end{tabular}

Grupo 1 nível baixo = até $20 \mathrm{mg} / \mathrm{mL}$ de $\mathrm{lgG}$

Grupo 2 nível médio $=$ entre 20 e $30 \mathrm{mg} / \mathrm{mL}$ de $\lg G$

Grupo 3 nível alto $=$ acima de $30 \mathrm{mg} / \mathrm{mL}$ de $\operatorname{lgG}$

$\mathrm{DP}=$ Desvio Padrão 


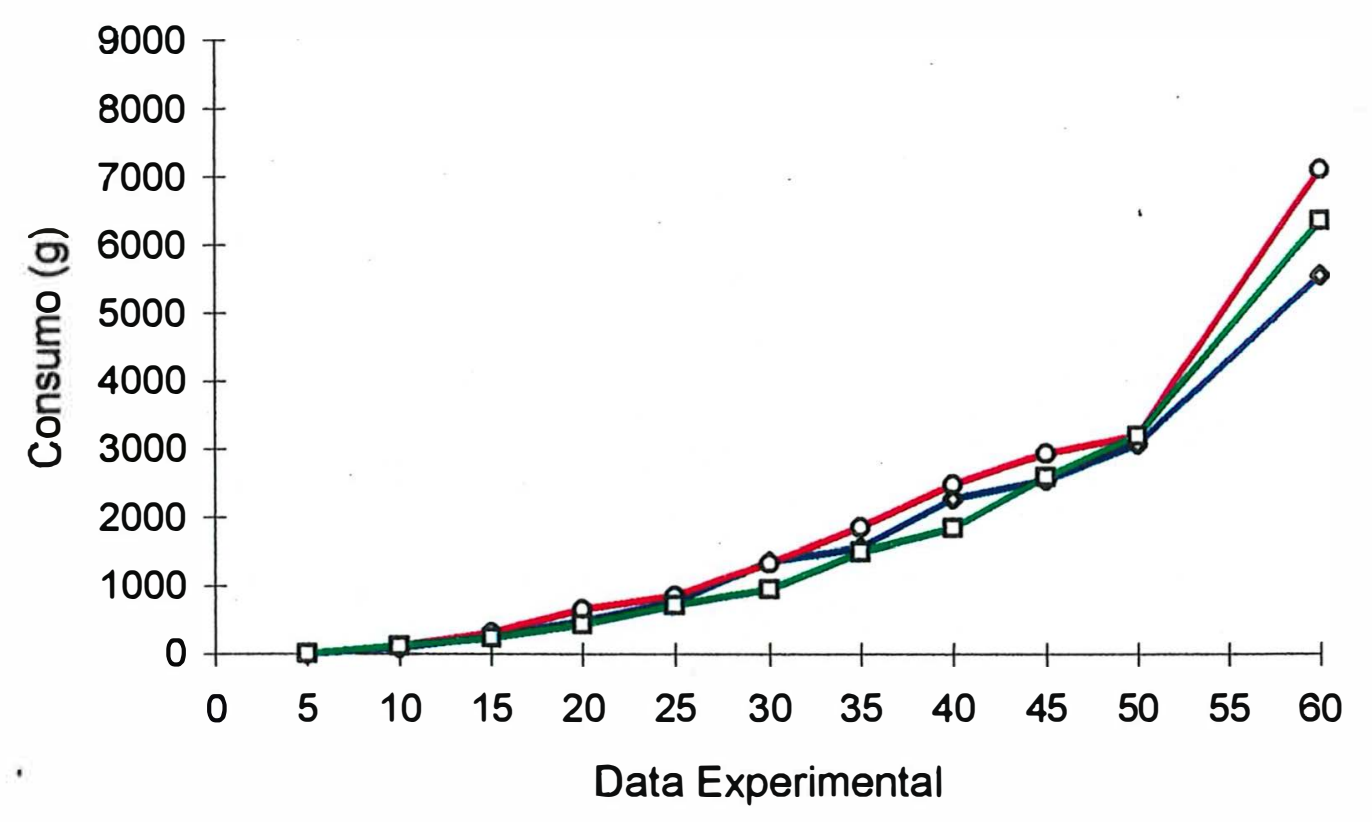

$\sim$ Grupo $1 \rightarrow$ Grupo $2 \rightarrow-$ Grupo 3

Figura 6. Consumo médio de concentrado (g) nos diferentes grupos experimentais.

Não houve diferença significativa entre os grupos para consumo de concentrado até 50 dias de idade. Já para o período entre 50 e 60 dias, os grupos apresentaram diferença significativa, sendo o consumo médio de concentrado do grupo $2,7708,33 \pm 1072,61 \mathrm{~g}$ superior aos grupos $3(p<0,0036)$ e 1 ( $p<0,0001$ ), com consumo médio de 6357,14 $\pm 1012,68 \mathrm{~g}$ e 5561,36 \pm $545,82 \mathrm{~g}$, respectivamente. Esse fato explica as diferenças encontradas no ganho de peso médio no final do período experimental entre 50 e 60 dias. As probabilidades encontradas para a comparação entre os grupos nas datas experimentais encontram-se na Tabela 20 do Apêndice. 
Alguns autores sugerem que a aquisição da proteção passiva pelo recém-nascido pode estar ligada ao seu tamanho. Kruse (1970) encontrou correlações positivas trabalhando com bezerros leiteiros com variação de peso entre 15 a $51 \mathrm{~kg}$ e aumento na concentração de imunoglobulinas séricas após a ingestão da primeira refeição de colostro nas primeiras 24 horas de vida. Para relacionarmos os dados obtidos com essa informação, os animais foram separados novamente, em três grupos, conforme a Tabela 15, tomando-se como critério de separação o peso vivo ao nascimento. Com isso pode-se avaliar a influência do peso inicial sobre a concentração inicial de lgG sérica.

Tabela 15. Separação dos animais em três grupos conforme o peso vivo ao nascimento.

\begin{tabular}{ccc}
\hline Grupo & Peso vivo ao nascimento & Unidades Experimentais \\
\hline Grupo 1 & acima de $40 \mathrm{~kg}$ & 17 \\
Grupo 2 & entre $35-40 \mathrm{~kg}$ & 23 \\
Grupo 3 & abaixo de $35 \mathrm{~kg}$ & 19 \\
\hline
\end{tabular}

Os dados médios de lgG sérica dos animais distribuídos por peso vivo inicial são apresentados na Tabela 16 e ilustrado na Figura 7.

As concentrações séricas iniciais de imunoglobulinas foram submetidas a análise de variância e não foram encontradas diferenças entre os grupos. Dobbelaar et al. (1987), trabalhando com bezerros leiteiros, também não encontraram correlação entre peso ao nascer e concentração de imunoglobulinas em uma faixa de peso variando de 35 a $40 \mathrm{~kg}$. Concordando com esse resultado, Robison et al. (1988) não encontraram correlação significativa entre concentração de imunoglobulinas nas primeiras 48 horas de vida e peso ao nascer (média de $39 \mathrm{~kg}$ ) em bezerros holandeses, mas encontraram influência da concentração de lg às 24 e 48 horas de vida em 
relação a taxa de crescimento do animal do nascimento até 180 dias de idade. Os autores sugerem que animais com adequada concentração de lg sérica inicial (concentrações de lg sérica maiores que $8 \mathrm{mg} / \mathrm{mL}$ ) entre 24 e 48 horas de vida geralmente são aptos a inativar invasores patogênicos mais cedo que os animais com baixas concentrações séricas. Portanto, esses animais continuam crescendo normalmente.

Tabela 16. Concentração média de lgG sérica $(\mathrm{mg} / \mathrm{mL})$ nos três grupos separados por peso inicial.

\begin{tabular}{cccc}
\hline Idade (dias) & $\begin{array}{c}\text { Grupo 1 } \\
\text { Média } \pm \text { DP }\end{array}$ & $\begin{array}{c}\text { Grupo 2 } \\
\text { Média } \pm \text { DP }\end{array}$ & $\begin{array}{c}\text { Grupo 3 } \\
\text { Média } \pm \text { DP }\end{array}$ \\
\hline $\mathbf{1}$ & $22,57 \pm 4,33$ & $24,60 \pm 2,48$ & $19,75 \pm 4,00$ \\
$\mathbf{5}$ & $20,59 \pm 3,67$ & $25,03 \pm 1,99$ & $19,04 \pm 3,39$ \\
$\mathbf{1 0}$ & $19,29 \pm 3,87$ & $22,82 \pm 1,90$ & $17,97 \pm 2,90$ \\
$\mathbf{1 5}$ & $19,06 \pm 3,48$ & $18,41 \pm 1,28$ & $15,56 \pm 2,50$ \\
$\mathbf{1 7}$ & $18,45 \pm 3,21$ & $17,86 \pm 1,37$ & $14,27 \pm 2,29$ \\
$\mathbf{2 0}$ & $16,54 \pm 2,89$ & $17,90 \pm 1,44$ & $14,91 \pm 2,15$ \\
$\mathbf{2 5}$ & $18,69 \pm 2,24$ & $16,57 \pm 1,18$ & $15,73 \pm 1,64$ \\
$\mathbf{3 0}$ & $17,86 \pm 2,03$ & $17,02 \pm 1,22$ & $15,06 \pm 1,53$ \\
$\mathbf{3 5}$ & $19,14 \pm 1,82$ & $16,92 \pm 1,08$ & $18,03 \pm 1,52$ \\
$\mathbf{4 0}$ & $19,34 \pm 1,78$ & $18,56 \pm 0,83$ & $19,05 \pm 1,71$ \\
$\mathbf{4 5}$ & $20,26 \pm 2,76$ & $20,18 \pm 1,21$ & $20,77 \pm 2,13$ \\
$\mathbf{5 0}$ & $21,73 \pm 2,42$ & $22,12 \pm 1,41$ & $21,54 \pm 1,91$ \\
$\mathbf{6 0}$ & $22,45 \pm 2,38$ & $23,84 \pm 1,74$ & $20,90 \pm 1,64$ \\
\hline
\end{tabular}

Grupo 1 animais acima de $40 \mathrm{~kg}$ de peso vivo inicial Grupo 2 animais entre 35 e $40 \mathrm{~kg}$ de peso vivo inicial Grupo 3 animais abaixo de $35 \mathrm{~kg}$ de peso vivo inicial $\mathrm{DP}=$ Desvio Padrão 


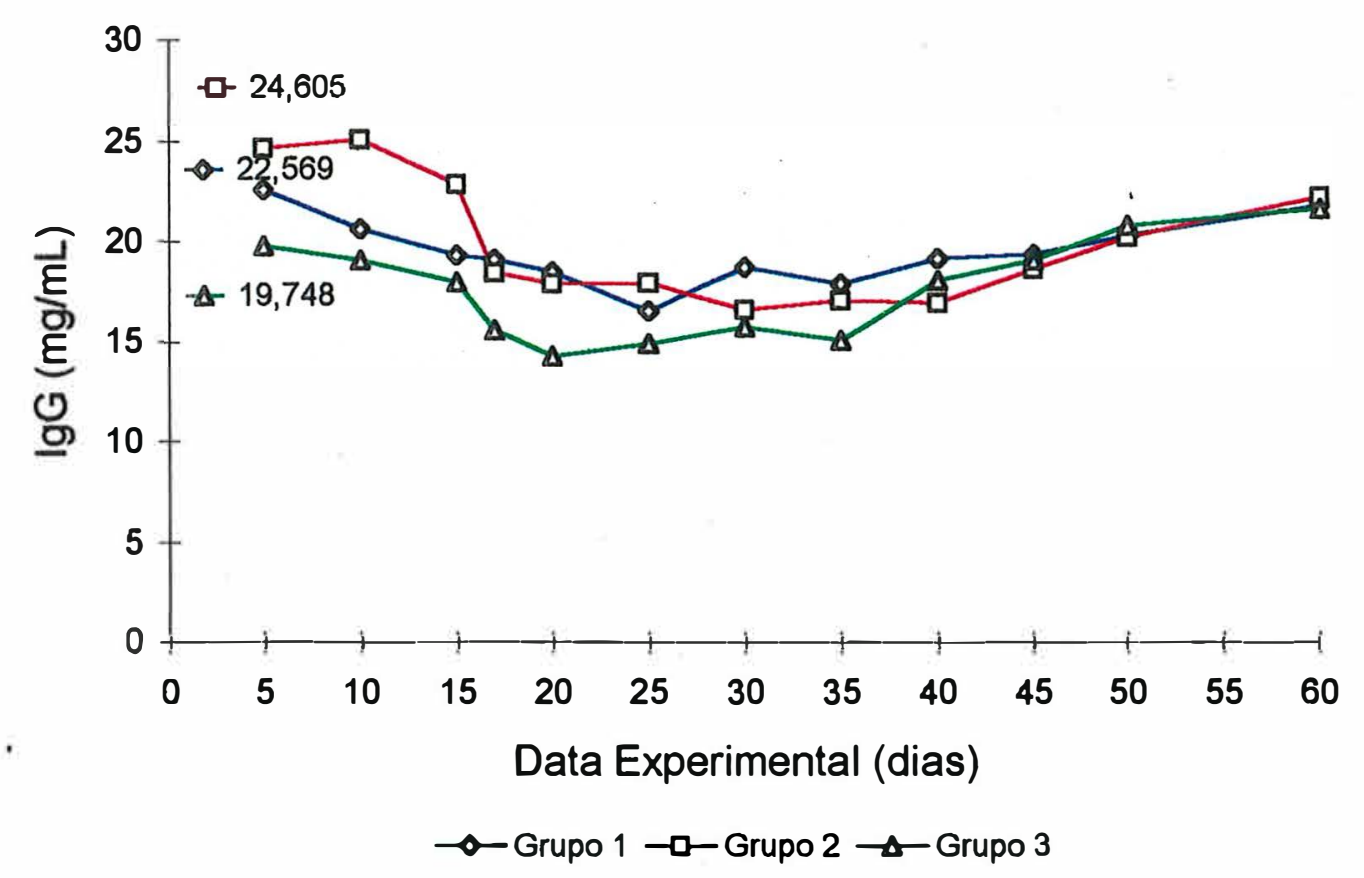

Figura 7. Flutuação da concentração média de $1 \mathrm{gG}$ sérica $(\mathrm{mg} / \mathrm{mL})$ nos grupos separados de acordo com peso vivo inicial.

Machado Neto et al. (1989) encontraram baixas correlações entre niveis de imunoglobulinas e peso ao nascimento em bezerros leiteiros. Já Ramin et al. (1996) não encontraram correlação entre peso ao nascer em grupos de bezerros leiteiros que tinham seus pesos iniciais variando de 22,3 \pm 3,2 até $40,8 \pm 4,0 \mathrm{~kg}$ e concentração de IgG entre 6 e 48 horas de vida. Não foram verificadas também correlações significativas entre concentração de IgG inicial e porcentagem de ganho de peso e início da puberdade aos 15 meses de idade. Os autores concluíram que a concentração de IgG inicial tem o objetivo maior de proteger os animais por poucas semanas de idade, mas não pode ser usada como uma variável apropriada para predizer o desempenho animal a longo prazo. Resultados semelhantes também foram encontrados por outros 
autores (Nocek et al., 1984; Caldow et al., 1988; Pires et al., 1993).

A interpretação dos resultados obtidos pelos estudos citados deve levar em consideração a raça do animal, bezerros de corte e bezerros leiteiros, como também a diferença de manejo entre tipos de criação. $O$ manejo do gado leiteiro, tanto pré como pós-parto é mais intensivo, contando com maior assistência, especialmente em relação ao recém-nascido, podendo determinar uma redução do efeito peso ao nascimento sobre a aquisição de imunidade passiva.

O fato da concentração inicial de lgG passiva não ter influído nos dados de desempenho animal pode ter como explicação a situação experimental realizada em condições de campo, na qual os animais foram somente amostrados sem nenhuma interferência na rotina de manejo das fazendas. Provavelmente, seriam necessárias situações mais extremas de manejo, situação não verificada no presente experimento, para identificar a influência da concentração inicial de lgG sérica sobre desempenho, pois animais, independentemente do status imunológico inicial, podem ter comportamento de lgG diferenciado devido a outros mecanismos não avaliados, mas importantes para identificação da relação de interdependência das variáveis. 


\section{CONCLUSÕES}

- O desempenho dos bezerros não foi influenciado pela pronunciada amplitude de variação da imunidade passiva adquirida do colostro.

- O catabolismo de anticorpos adquiridos passivamente e a estimulação da síntese endógena de anticorpos não influíram no desempenho dos animais.

- O catabolismo e a síntese de anticorpos ocorrem no início da vida dos bezerros no sentido de alcançar valores fisiológicos adequados ao sistema. 


\section{REFERÊNCIAS BIBLIOGRÁFICAS}

ABRAHAMSON, D.R.; RODEWALD, R. Evidence for the sorting of endocytic vesicle contents during the receptor-mediated transport of IgG across the newborn rat intestine. The Journal of Cell Biology, v.91, n.01, p.270-280, Oct. 1980.

ALDRIDGE, B.M.; McGUIRK, S.M.; LUNN, D.P. Effect of colostral ingestion on immunoglobulin-positive cells in calves. Veterinary Immunology and Immunopathology, v.62, n.1, p.51-64, Mar. 1998.

ARGENZIO, A. Digestão, absorção e metabolismo. In: SWENSON, M.J. Dukey's Fisiologia dos Animais Domésticos. $10^{\mathrm{a}}$ ed., Ithaca: Cornell University Press, 1984, cap.3, p.263-264.

ARTHINGTON, J. Managing colostrum in the newborn calf. Large Animal Practice, v.18, n.15, p.29-33, Sep./Oct. 1997.

AVRECH, O.M.; SAMRA, Z.; LAZAROVICH, Z.; CASPI, E.; JACOBOVICH, A.; SOMPOLINSKY, D. Efficacy of the placental barrier for immunoglobulins: correlations between maternal, paternal and fetal immunoglobulins levels. International Archive Allergy Immunology, v.103, n.02, p.160-165, Feb. 1994.

BARACAT, R.S.; MACHADO NETO, R.; DANIELE, C.; BESSI, R.; PACKER, I.U. Influência do fornecimento prolongado de colostro sobre a flutuação de proteínas séricas em bezerros com diferentes níveis de imunidade passiva sérica. Scientia Agricola, v.52, n.3, p.537-542, set./dez. 1995.

BARACAT, R.S.; MACHADO NETO, R.; DANIELE, C.; BESSI, R.; PACKER, I.U. Fornecimento prolongado de colostro e proteção passiva em bezerros recémnascidos. Pesquisa Agropecuária Brasileira, v.32, n.11, p. 215-1220, nov. 1997. 
BESSER, T.E.; GARMEDIA, A.E.; McGUIRE, T.C.; GAY, C.C. Effects of colostral immunoglobulin $G_{1}$ and immunoglobulin $M$ concentrations on immunoglobulin absorption in calves. Journal of Dairy Science, v.68, n.08, p.2033-2037, Aug. 1985.

BESSER, T.E.; GAY, C.C. The importance of colostrum to the health of neonatal calf. Veterinary Clinics of North America: Food Animal Practice. v.10, n.1, p. 107-115, Mar. 1994.

BESSER, T.E.; GAY, C.C.; PRITCHETT, L. Comparison of three methods of feeding colostrum to dairy calves. Journal of the American Veterinary Medical Association, v.198, n.3, p. 419-422, Feb. 1991.

BESSER, T.E.; SZENCI, O.; GAY, C.C. Decreased colostral immunoglobulin absorption in calves with postnatal respiratory acidosis. Journal of the American Veterinary Medical Association, v.196, n.8, p.1229-1234, Apr. 1990.

$B E S S I, R$. Efeito de selênio e vitamina $E$ sobre o desenvolvimento imunológico de bezerros. Piracicaba, 1996. 102p. Dissertação (M.S.) - Escola Superior de Agricultura "Luiz de Queiroz", Universidade de São Paulo.

BLECHA, F.; POLLMANN, D.S.; NICHOLS, D.A. Weaning pigs at an early age decreases cellular immunity. Journal of Animal Science, v.56, n.2, p.396400, Feb. 1983.

BORGES, A.S. Avaliação da eficácia da administração de plasma, por via intravenosa, como tratamento da falência de transferência de imunidade passiva em bezerros da raça Holandesa. São Paulo, 1997. 84p. Dissertação (M.S.) - Faculadade de Medicina Veterinária e Zootecnia, Universidade de São Paulo.

BOURNE, F.J.; NEWBY, T.J. Mucosal immunity in the pig. Pig News and Information, v.2, n.2, p.141-145, 1981.

BOYD, J.W. The relantionship between serum immune globulin deficiency and disease in calves: a farm survey. Veterinary Record, v.90, n.23, p.645-649, June 1972.

BRADLEY, J.A.; NIILO, L. Immunoglobulin transfer and weight gain in suckled beef 
calves force-fed stored colostrum. Canadian Journal of Comparative Medicine, v.49, n.2, p.152-155, 1985.

BRAMBELL, F.W.R. The passive immunity of the young mammal. Biological Reviews, v.33, n.4, p.488-531, Nov. 1958.

BRANDON, M.R.; LASCELLES, A.K. Relative efficiency of absorption of $\lg _{1}$, $\lg _{2}, \lg A$ and $\lg M$ in the newborn calves. Australian Journal of Experimental Biology and Medical Science, v.49, n.6, p.629-633, Dec. 1971.

BRIGNOLE, T.J.; STOTT, G.H. Effect of suckling followed by bottle feeding colostrum on immunoglobulin absorption and calf survival. Journal of Dairy Science, v.63, n.3, p.451-456, Mar. 1980.

BUSH, L.J.; AGUILERA, M.A.; ADAMS, G.D. Absorption of colostral immunoglobulins by newborn dairy calves. Journal of Dairy Science, v.54, n.10, p.1547-1549, Oct. 1971.

BUSH, L.J.; STALEY, T.E. Absorption of colostral immunoglobulins in newborn calves. Journal of Dairy Science, v.63, n.4, p.672-680, Apr. 1980.

BUTLER, J.E. Bovine immunoglobulins: A review. Journal of Dairy Science, V.52, p.1895-1909, 1969.

CALDOW, G.L.; WHITE, D.G.; KELSEY, M.; PETERS, A.R.; SOLLY, K.J. Relationship of calf antibody status to disease and performance. Veterinary Record, v.122, n.3, p.63-65, Jan. 1988.

COMLINE, R.S.; ROBERTS, H.E.; TITCHEN, D.A. Route of absorption of colostrum globulin in the newborn animal. Nature, v.167, p.561-562, 1951.

CRENSHAW, T.D.; COOK, M.E.; ODLE, J.; MARTIN, R.E. Effect of nutritional status, age at weaning and room temperature on growth and systemic immune response of weaning pigs. Journal of Animal Science, v.63, n.6, p.18451853, Dec. 1986.

DANIELE, C. Efeito de diferentes manejos de fornecimento prolongado de colostro sobre o desempenho imunológico de bezerros leiteiros recémnascidos. Piracicaba, 1993. 139p. Dissertação (M.S.) - Escola Superior de Agricultura "Luiz de Queiroz", Universidade de São Paulo.

DANIELE, C.; MACHADO NETO, R.; BARACAT, R.S.; BESSI, R.; PACKER, I.U. 
Efeito de diferentes manejos no fornecimento prolongado de colostro sobre $o$ comportamento imunológico e desempenho de bezerros leiteiros recémnascidos. Revista da Sociedade Brasileira de Zootecnia, v.23, n.2, p.211222, mar./abr. 1994a.

DANIELE, C.; MACHADO NETO, R.; BARACAT, R.S.; BESSI, R.; PACKER, I.U. Efeito de diferentes manejos de fornecimento prolongado de colostro sobre os níveis de proteína e albumina séricas e desempenho de bezerras recémnascidas. Scientia Agricola, v.5, n.2, p.381-388, maio/ago. 1994b.

DEVERY, J.E.; DAVIS, C.L.; LARSON, B.L. Endogenous production of immunoglobulin $\lg _{1}$ in newborn calves. Journal of Dairy Science, v.62, n.11, p.1814-1818, Nov. 1979.

DIAZ, M.D.P. Estudo da lei de auto-desbaste através de ajuste de modelos lineares e não-lineares, em povoamentos de Eucalyptus grandis, no Estado de São Paulo. Piracicaba, 1992. 92p. Dissertação (M.S.) - Escola Superior de Agricultura "Luiz de Queiroz", Universidade de São Paulo.

DIXON, F.J.; WEIGLE, W.O.; VAZQUEZ, J.J. Metabolism and mammary secretion of serum proteins in the cow. Laboratory Investigation, v.10, p.216-236, 1961.

DOBBELAAR, P.; NOORDHUIZEN, J.P.T.M.; VAN KEULEN, K.A.S. An epidemiological study of gammaglobulin levels in newborn calves. Preventive Veterinary Medicine, v.5, n.1, p.51-62, 1987.

DONOVAN, G.A.; BADINGA, L.; COLLIER, R.J.; WILCOX, C.J.; BRAUN, R. K. Factors influencing passive transfer in dairy calves. Journal of Dairy Science, v.69, n.3, p.754-759, Mar. 1986.

EDWARDS, S.A.; BROOM, D.M.; COLLIS, S.C. Factors affecting levels of passive immunity in dairy calves. British Veterinary Journal, v.138, n.3, p.233-240, May/ June 1982.

FAGLIARI, J.J.; FERREIRA NETO, J.M.; LUCAS, A.; NETO, J.A. Proteína total e fracionamento eletroforético do soro de bezerros Guzerá passivamente imunizados contra paratifo. Arquivo Brasileiro de Medicina Veterinária e Zootecnia, v.35, n.3, p.317-332, jun. 1983. 
FERRI, R.B.; CALICH, V.L.G.; COPPI VAZ, C.A. Imunologia. 2.ed. São Paulo: Artes Médicas, 1979. 317p.

FLEENOR, W.A.; STOTT, G.H. Hydrometer test for estimation of immunoglobulin concentration in bovine colostrum. Journal of Dairy Science, v.63, n.6, p.979-977, June 1981.

FOLEY, J.A.; OTTERBY, D.E. Availability, storage, treatement composition and feeding value of surplus colostrum: A Review. Journal of Dairy Science, v.61, n.8, p.1033-1060, Aug. 1978.

GARRY, F.B.; ADAMS, R.; CATTELL, M.B.; DINSMORE, R.P. Comparison of passive immunoglobulin transfer to dairy calves fed colostrum or commercially avaible colostral supplement products. Jounal of the American Veterinary Medical Association, v.208, n.1, p.107-110, Jan. 1996.

GAY, C.C.; ANDERSON, N.; FISHER, E.W.; McEWAN, A.D. Gammaglobulin levels and neonatal mortality in market calves. Veterinary Record, v.77, n.34, p.148-149, Aug. 1965.

GAY,C.C. Colostrum research says... fed 4 quarts for healthier calves. Hoard's Dairyman, v.139, n.6, p.256, 1994.

HOPKINS, B.A. Effects of the method of calf starter delivery and effects of weaning age on starter intake and growth of holstein calves fed milk once daily. Journal of Dairy Science, v.80, n.9, p. 2200-2203, Sep. 1997.

HOPKINS, B.A.; QUIGLEY, J.D. III Effects of the method of colostrum feeding and colostrum supplementation on concentrations of immunoglobulin $G$ in the serum of neonatal calves. Journal of Dairy Science, v.80, n.5, p. 979-983, May 1997.

HUSBAND, A.J.; BRANDON, M.R.; LASCELLES, A.K. Absorption and endogenous production of immunoglobulins in calves. Australian Journal of Experimental Biology and Medical Science, v.50, n.4, p.491-498, Sep. 1972.

HUSBAND, A.J.; BRANDON, W.R.; LASCELLES, A.K. The effect of corticosteroid on absorption and endogeneous production of immunoglobulins in calves. Australian Journal of Experimental Biology and Medical Science, v.51, 
n.5, p.707-710, Oct. 1973.

HUSBAND, A.J.; LASCELLES, A.K. Antibody responses to neonatal immunization in calves. Research in Veterinary Science, v.18, n.2, p.201-207, 1975.

JAMES, R.E.; POLAN, C.E.; McGILLIARD, M.L. Distribuition uptake of $\gamma$-globulin in small intestine of neonatal calves. Journal of Dairy Science, v.62, n.9, p.1415-1419, Sep. 1979.

JEFFCOTT, L.B. Passive immunity and its transfer with special reference to the horse. Biological Reviews, v.47, n.4, p.439-464, Nov. 1972.

JENNY, B.F.; GRAMLINS, G.E.; GLAZE, T.M. Management factors associated with calf mortality in South Carolina dairy herds. Journal of Dairy Science, v.64, n.11, p.2284-2289, Nov. 1981.

KLAUS, G.G.B.; BENNET, A.; JONES, E.W. A quantitative study of the transfer of colostral immunoglobulins to the newborn calf. Immunology, v.16, n.3, p.293299, Mar. 1969.

KRUSE, P.E. Absorption of immunoglobulin from colostrum in newborn calves. Animal Production, v.12, n.4, p.627-638, 1970.

KRUSE, P.E. The importance of colostral immunoglobulin and their absorption from the intestine of the newborn animals. Annales de Recherches Veterinaires, v.14, n.4, p.349-353, 1983.

LANCE, S.E.; MILLER, G.Y., HANCOCK, D.D.; BARTLETT, P.C.; LAWRENCE. E.H.; MOESCHBERGER, M.L. Effects of environment and management on mortality in preweaned dairy calves. Journal of Americam Veterinary Medical Association, v.201, n.8, p.1197-1202, Oct. 1992.

LARSON, B.L.; KENDALL, K.A. Changes in specific blood serum protein levels associated with parturition in the bovine. Journal of Dairy Science, v.40, p.659-666, 1957.

LECCE, J.D.; MORGAN, D.O. Effect of dietary regime on cessation of intestinal absorption of large molecules (closure) in the neonatal pig and lamb. Journal of Nutrition, v.78, n.3, p.263-268, Nov. 1962.

LECCE, J.G. Effect of dietary regime on cessation of uptake of macromolecules by piglet intestinal epithelium (closure) and transport to the blood. Journal of 
Nutrition, v.103, p.751-756, 1973.

LOGAN, E.F.; McBEATH, D.G.; LOWMAN, B.G. Quantitative studies of serum immunoglobulin levels in suckled calves from birth to five weeks. Veterinary Record, v.94, n.16, p.367-370, Apr. 1974.

LOGAN, E.F; McMURRAY, C.H.; O'NEILL, D.G.; McPARLAND, P.J.; McRORY, F.J. Absorption of colostral immunoglobulins by the neonatal calf. British Veterinary Journal, v.134, n.3, p.258-262, May/June 1978.

LOPEZ, J.W.; STANLEY, D.A.; MITCHELL, J.; QUINN, M. Rotavirus and cryptosporidium shedding in dairy calf feces and its relantionship to colostrum immune transfer. Journal of Dairy Science, v.71, n.5, p.1288-1294, May 1988.

LOSINGER, W.C.; HEINRICHS, A.J. Management practices associated with high mortality among preweaned dairy heifers. Journal of Dairy Research, v.64, n.1, p.1-11, 1997.

LUCCI, C. Bovinos Leiteiros Jovens. São Paulo: Nobel/Editora da Universidade de São Paulo, 1989. 371p.

MACHADO NETO, R.; PACKER, I.U. Flutuação de imunoglobulina sérica em bezerros da raça holandesa submetidos a diferentes regimes de aleitamento. Revista da Sociedade Brasileira de Zootecnia, v.15, n.5, p.439-447, set./out. 1986.

MACHADO NETO, R.; PACKER, I.U.; BONILHA, L.M.; FIGUEIREDO, L.A.; RAZZOK, A.G.; CÂNDIDO, J.G. Concentração de lgG sérica em bezerros das raças Nelore, Guezerá, Gir e Caracu. 1. Estatísticas descritivas e causas de variação. Revista Brasileira de Zootecnia, v.26, n.5, p.914-919, set./out. $1997 a$.

MACHADO NETO, R.; PACKER, I.U.; BONILHA, L.M.; FIGUEIREDO, L.A.; RAZZOK, A.G.; CÂNDIDO, J.G. Concentração de lgG sérica em bezerros das raças Nelore, Guzerá, Gir e Caracu. 2. Efeitos sobre crescimento e mortalidade até a desmama. Revista Brasileira de Zootecnia, v.26, n.5, p.920-923, set./out. 1997b.

MACHADO NETO, R.; PACKER, I.U.; SUSIN, I. Concentração de imunoglobulina 
sérica, peso corporal e diarréia em bezerros da raça Holandesa aleitados com diferentes dietas. Turrialba, v.39, n.1, p.51-55, jan./mar. 1989.

MANCINI, G.; CARBONARA, A.O.; HERMANS, J.F. immunochemical quantitation of antigens by single radial immunodiffusion. Immunochemistry, v.2, n.3, p.253-254, Sep. 1965.

MATTE, J.J.; GIRARD, C.L.; SEOANE, J.R.; BRISSON, G.J. Absorption of colostral immunoglobulins $G$ in the newborn dairy calf. Journal of Dairy Science, v.65, n.9, p.235-254, Sep. 1982.

McCOY, G.C.; RENEAU, J.K.; HUNTER, A.G.; WILLIAMS, J.B. Effects of diet and time on blood serum proteins in the newborn calf. Journal of Dairy Science, v.53, n.3, p.358-362, Mar. 1970.

McGUIRE, T.C.; PFEIFFER, N.E.; WEIKEL, J.M.; BARTSCH, R.C. Failure of colostral immunoglobulin transfer in calves dying from infections disease. Journal of the American Veterinary Medical Association, v.169, n.7, p.713718, Oct. 1976.

MEE, J.F.; O'FARREL, K.J.; REITSMA, P.; MEHRA, R. Effect of a whey protein concentrate used as a colostrum substitute or supplement on calf immunity, weight gain, and health. Journal of Dairy Science, v.79, n.5, p.886-894, May 1996.

MICHANEK, P.; VENTORP, M.; WESTROM, B. Intestinal transmission of colostral antibodies in newborn dairy calves - Initiation of closure by feeding colostrum. Swedish Journal of Agricultural Research, v.19, n.2, p.125-127, 1989.

MICHANEK, P.; VENTORP, M.; WESTROM, B. Milk intake before first colostrum innewborn dairy calves. Effect on intestinal transmission of macromolecules. Journal of Dairy Science, v.73, n.2, p.480-483, Feb. 1990.

MORIN, D.E.; McCOY, G.C.; HURLEY, W.L. Effects of quality, quantity, and timing of colostrum feeding and addition of a dried colostrum supplement on immunogloblin $G_{1}$ absorption in Holstèin bull calves. Journal of Dairy Science, v.80, n.4, p.747-753, Apr. 1997.

MULLER, L.D.; ELLINGER, D.K. Colostral Immunoglobulins concentration among breeds of dairy cattle. Journal of Dairy Science, v.64, n.8, p.1727-1730, Aug. 
1981.

NEWBY, T.J.; MILLER, B.G.; STOKES, C.R.; HAMPSON, D.J.; BOURNE, F.J. Local hypersensitivity response to dietary antigens in early weaned pigs. In: COLE, D.J.A.; HARESIGN, W. Recent Developments in Pig Nutrition. London: Butterworths, 1988, p.211-221.

NEWBY, T.J.; STOKES, C.R.; BOURNE, F.J. Immunological activities of milk. A review. Veterinary Immunology and Immunopathology, v.3, n.1, p.67-94, Jan. 1982.

NOCEK, J.E.; BRAUND, D.G.; WARNER, R.G. Influence of nenatal colostrum administration, immunoglobulin, and continued feeding of colostrum on calf gain, health and serum protein. Journal of Dairy Science, v.67, n.2, p.319333, Feb. 1984.

OYENIYI, O.O.; HUNTER, A.G. Colostral constituents including immunoglobulins in the first three milkings postpartum. Journal of Dairy Science, v.61, n.1, p.4448, Jan. 1978.

PENHALE, W.J.; LOGAN, E.F.; SELMAN, I.E.; FISHER, E.W.; McEWAN, A.D. Observations on the absorption of colostral immunoglobulin by neonatl calf and their significance in colibacilosis. Annales de Recherches Veterinaires, v.4, n.1, p.223-233, 1973.

PERINO, L.J.; WITTUN, T.E. Effects of various risck factors on plasma protein and serum immunoglobulin concentration of calves at postpartum hours 10 and 24 . American Journal of Veterinary Research, v.56, n.9, p.1144-1148, Sep. 1995.

PERINO, L.J; RUPP, G.P. Immunization of the beef cow and its influence on fetal and neonatal calf health. Veterinary Clinics of North America: Food Animal Practice, v.10, n.1,p.15-34, Mar. 1994.

PIRES, M. de F.A.; CAMPOS, de F.O.; CHARLES, T.N.P.; DURÃES, M.C. Alguns fatores que afetam o nível das imunoglobulinas no soro dos bezerros de rebanhos leiteiros. Revista da Sociedade Brasileira de Zootecnia, v.22, n.6, p.984-992, 1993.

PORTER, P. Immunoglobulin mechanisms in health and nutrition from birth to 
weaning. Proceedings of the Nutrition Society, v.35, n.3, p.273-282, 1976.

PORTER, P. Immunoglobulins in bovine mammary secretions. Quantitatives changes in early lactation and by the neonatal calf. Immunology, v.23, n.2, p.225-238, Aug. 1972.

PORTER, P. Structural and functional characteristics of immunoglobulins of the common domestic especies. Advances in Veterinary Science and Comparative Medicine, v.23, p.1-21, 1979.

PORTER, P. The immune system. In: DUNNE, H. W.; LEMAN, A. D Disease of Swine., 1975. 1212p.

QUIGLEY, J.D.III; FIKE, D.L.; EGUTON, M.N.; DREWRY, J.J; ARTHINGTON, J.D. Effects of a colostrum replacement product derived from serum on immunoglobulin $\mathrm{G}$ absorption by calves. Journal of Dairy Science, v.81, n.7, p.1936-1939, July 1998.

QUIGLEY, J.D.III; MARTIN, K.R.; BEMIS, D.A.; POTGIETER, L.N.D.; REINEMEYER, C.R.; ROHRBACH, B.W.; DOWLEN, H.H.; LAMAR, K.C. Effects of housing and colostrum feeding on serum immunoglobulins growth, and fecal scores of Jersey calves. Journal of Dairy Science, v.78, n.4, p.893901, Apr. 1995a.

QUIGLEY, J.D.III; MARTIN, K.R.; DOWLEN, H.H. Concentrations of trypsin inhibitor and immunoglobulins in colostrum of Jersey cows. Journal of Dairy Science, v.78, n.7, p.1573-1577, July 1995b.

RAJALA, P.; CASTRÉN, H. Serum immunoglobulin concentrations and health of dairy calves in two management systems from birth to 12 weeks of age. Journal of Dairy Science, v.78, n.12, p.2737-2744, Dec. 1995.

RAMIN, A.G.; DANIEL, R.C.W.; FENWICK, D.C; VERRAL, R.G. Serum immunoglobulin concentrations in young dairy calves and their relationships with weight gain, onset of puberty and pelvic area at 15 months of age. Livestock Productions Science, v.45, n.2-3, p.155-162, May 1996.

REINHOLD, J.G. Total protein, albumin and globulin. In: REINER, M. Standard Methods of Clinical Chemistry. New York: Academic Press, 1953, v.1, p. 88. RIBEIRO, M.F.B.; BELEM, P.A.D.; PATARROYO, J.H.S.; FARIA, J.E. de. 
Hipogamaglobulinemia em bezerros. Arquivo Brasileiro de Medicina Veterinária e Zootecnia, v.35, n.4, p.537-546, ago. 1983.

ROBISON, J.D.; STOTT, G.H.; DENIDE, S.K. Effects of passive immunity on the growth and survival in the dairy heifer. Journal of Dairy Science, v.71, n.5, p.1283-1287, May 1988.

RODEWALD, R. Distribution of immunoglobulin $G$ receptors in the small intestine of the young rat. Journal of Cell Biology, v.85, n.1, p.18-32, Apr. 1980.

RODEWALD, R. Intestinal transport of antibodies in the newbom rat. Journal of Cell Biology, v.58, n.1, p.189-211, July 1973.

RODEWALD, R. pH-dependent binding of immunglobulins to intestinal cells of the neonatal rat. Journal of Cell Biology, v.71, n.2, p.666-670, Nov. 1976.

ROY, J.H.B. The calf: Management of health. 5.ed. London: Butterworths, 1990. 258p.

SAS INSTITUTE SIA. SAS/STAT: user's guide. Release 6.08 ed. Cary: SAS Institute Inc., 1989. 1028p.

SASAKI, M.; DAVIS, C.L.; LARSON, B.L. Production and tumover of $\lg G_{1}$ and $\lg G_{2}$ immunoglobulins in the bovine around parturation. Journal of Dairy Science, v.59, n.12, p. 2046-2055, Dec. 1976.

SELMAN, I.E.; de LA FUENTE, G.H.; FISHER, E.W.; McEWAN, A.D. The serum immune globulin concentration of newborn dairy heifer calves. A farm survey. Veterinary Record, v.88, p.460-464, 1971.

SHELL, T.M.; EARLY, R.J.; CARPENTER, J.R. Prepartum nutrition and solar radiation in beff cattle:Il. Residual effects on postpartum milk yield, immunoglobulin and calf growth. Journal of Animal Science, v.73, n.5, p.1303-1309, May 1995.

SIMPSON, M.M.W.; SMEATON, T.C. The transfer of antibodies by neonates and adults. Advances in Veterinary Science and Comparative Medicine, v.16, p.355-381, 1972.

SMITH, K.L.; MUIR, L.A.; FERGUSON, L.C.; CONRAD, H.R. Selective transport of $\lg G_{1}$ into mammary gland: Role of estrogen and progesterone. Journal of 
Dairy Science, v.54, n.12, p.1886-1894, Dec. 1971.

SMITH, T.; LITTLE, R.B. The significance of colostrum to the newborn calf. Journal of Experimental Medicine, v.36, p.181-198, 1922.

SNODGRASS, D.R.; WELLS, P.W. The influence of colostrum of neonatal rotaviral infection. Annales de Recherches Veterinaires, v.9, n.2, p.335-336, 1978.

STAHLY, T. Immune system activation affects pig growth, nutrients needs. Feedstuffs, v. 24, p. 12-13, Oct. 1994.

STALEY, T.E.; BUSH, L.J. Receptor mechanisms of the neonatal intestine and their relationship to immunoglobulin absorption and disease. Journal of Dairy Science, v.68, n.1, p.184-205, Jan. 1985.

STOTT, G.H.; FELLAH, A. Colostral immunoglobulin absorption linearly related to concentration for calves. Journal of Dairy Science, v.66, n.6, p.1319-1328, June 1983.

STOTT, G.H.; FLEENOR, W.A.; KLESE, W.C. Colostral immunoglobulin concentrations in two fractions of first milking post-partum and five additional milkings. Journal of Dairy Science, v.64, n.3, p.459-465, Mar. 1981.

STOTT, G.H.; MARX, D.B.; MENEFEE, B.E.; NIGHTENGALE, G.T. Colostral immunoglobulin transfer in calves I. Period of absorption. Journal of Dairy Science, v.62, n.11, p.1632-11638, Nov. 1979a.

STOTT, G.H.; MARX, D.B.; MENEFEE, B.E.; NIGHTENGALE, G.T. Colostral immunoglobulin transfer in calves II. The rate of absorption. Journal of Dairy Science, v.62, n.11, p.1766-1773, Nov. 1979b.

STOTT, G.H.; MARX, D.B.; MENEFEE, B.E.; NIGHTENGALE, G.T. Colostral immunoglobulins transfer in calves. IV. Effect of suckling. Journal of Dairy Science, v.62, n.12, p.1908-1913, Dec. 1979c.

STOTT, G.H.; MENEFEE, B.E. Selective absorption of colostral immunoglobulin $\operatorname{lgM}$ in the newborn calf. Journal of Dairy Science, v.61, n.4, p.461-466, Apr. 1978

STOTT, G.H.; WIERSMA, F.; MENEFEE, B.E.; RADWANSKI, F.R. Influence of environment on passive immunity in calves. Journal of Dairy Science, v.59, n.7, p.1306-1310, July 1976 . 
TENNANT, D.V.M., HARROLD, D.B.S.; REINA-GUERRA, M.B.S.; LABEN, R.C. Neonatal alterations in serum gamma globulin levels of Jersey and holsteinfriesian calves. American Journal of Veterinary Research, v.30, n.3, p.345354, Mar. 1969.

TIZARD, I. Imunologia Veterinária. São Paulo: Livraria Roca Ltda., 1985. 329p.

TODD, A.G.; WHYTE, P.B.D. The effect of delay in feeding colostrum and the relationship between immunoglobulin concentration in serum of neonatal calves and their rates of growth. Australian Veterinary Journal, v.72, n.11, p.415-417, Nov. 1995.

VAN HEUGTEN, E.; SPEARS, J.W.; COFFEY, M.T. The effect of dietary protein on performance and immune response in weanling pigs subjected to an inflammatory challenge. Journal of Animal Science, v.72, n.10, p.2661-2669, Oct. 1994.

VENTORP, M.; MICHANEK, P. The importance of udder and teat conformation for teat seeking by the newborn calf. Journal of Dairy Science, v.75, n.1, p.262268, Jan. 1992.

WATSON, D.L. Immunological functions of the mammary gland and its scretion comparative review. Australian Journal of Biological Science, v.33, n.4, p.403-422, Aug. 1980.

WILLIAMS, N.H.; STAHLY, T.S.; ZIMMERMAN, D.R. Impact of system activation and dietary amino acid regime on nitrogen retention of pigs. Journal of Animal Science, v.71, n.1, p.171, Jan. 1993a.

WILLIAMS, N.H.; STAHLY, T.S.; ZIMMERMAN, D.R.; WANNEMUEHLER, M. Impact of system activation on the amino acid needs of pigs. Journal of Animal Science, v.71, n.1, p. 61, Jan. 1993b.

WITTUM, T.E.; PERINO, L.J. Passive immune status at postpartu hour 24 and long-term health and performance of calves. American Journal of Veterinary Research, v.56, n.9, p. 1149-1154, Sep. 1995.

ZANETTI, M.A. Influência da suplementação de colostro no balde do $2^{\circ}$ ao $5^{\circ}$ dia de vida sobre o nivel sérico de imunoglobulina de bezerros. Brazilian Journal of Veterinary Research Animal Science, v.27, n.2, p.267-283, 1990. 


\section{APÊNDICE}


Apêndice 1. Composição e níveis de garantia do concentrado usado na Fazenda Tainá.

\begin{tabular}{lc}
\hline Umidade (máximo) & $13.00 \%$ \\
Proteína bruta (mínimo) & $16.00 \%$ \\
Extrato etéreo (mínimo) & $2.00 \%$ \\
Matéria fibrosa (máximo) & $10.00 \%$ \\
Matéria mineral (máximo) & $12.00 \%$ \\
Cácio (máximo) & $2.00 \%$ \\
Fósforo (mínimo) & $0.50 \%$ \\
Vitamina A & $8000.00 \mathrm{U} .1 . / \mathrm{kg}$ \\
Vitamina B1 & $5.50 \mathrm{mg}$ \\
Vitamina B2 & $5.50 \mathrm{mg}$ \\
Vitamina B6 & $5.50 \mathrm{mg}$ \\
Vitamina B12 & $0.06 \mathrm{mg}$ \\
Vitamina D3 & $2000.00 \mathrm{U} .1 . / \mathrm{kg}$ \\
Vitamina E & $50 \mathrm{Ul} / \mathrm{kg}$ \\
Acido Nicotínico & $2.00 \mathrm{mg}$ \\
Pantotenato de Cálcio & $11.00 \mathrm{mg}$ \\
Biotina & $0.10 \mathrm{mg}$ \\
Cobalto & $0.20 \mathrm{mg}$ \\
Cobre & $16.00 \mathrm{mg}$ \\
Ferro & $80.00 \mathrm{mg}$ \\
lodo & $1.00 \mathrm{mg}$ \\
Manganês & $65.00 \mathrm{mg}$ \\
Selênio & $0.50 \mathrm{mg}$ \\
Zinco & $65.00 \mathrm{mg}$ \\
Antioxidante & $125.00 \mathrm{mg}$ \\
Promotor de crescimento & $50.00 \mathrm{mg}$ \\
\hline
\end{tabular}

Composição Básica do Produto: Calcário Calcítico, Farelo de Algodăo, Farelo de Trigo, Milho Integral Moido, Cloreto de Sódio (Sal Comum), Melaço, Premix Vitamínico Mineral.

Eventuais Substitutivos: Farelo de Alfafa, Farelo de Arroz Desengordurado, Farelo de Aveia, Fosfato Bicalcio, Levedura Seca de Cana-de-Açúcar, Óleo de Soja Degomado, Sorgo Integral Moido, Refinazil, Gérmen de Milho. 
Apêndice 2. Composição e níveis de garantia do concentrado usado no Departamento de Produção Animal - ESALQ/USP.

\begin{tabular}{lc}
\hline Umidade (máximo) & $13.00 \%$ \\
Proteína bruta (mínimo) & $18.00 \%$ \\
Extrato etéreo (mínimo) & $2.50 \%$ \\
Matéria fibrosa (máximo) & $6.00 \%$ \\
Matéria mineral (máximo) & $10.00 \%$ \\
Cácio (máximo) & $1.20 \%$ \\
Fósforo (mínimo) & $0.50 \%$ \\
Vitamina A & $18000.00 \mathrm{U} .1 . / \mathrm{kg}$ \\
Vitamina B12 & $22 \mathrm{mcg}$ \\
Vitamina D3 & $6000.00 \mathrm{U} .1 . / \mathrm{kg}$ \\
Vitamina E & $60.00 \mathrm{Ul} / \mathrm{kg}$ \\
Nlacina & $300.00 \mathrm{mg}$ \\
Riboflavina & $3.20 \mathrm{mg}$ \\
Ácido Pantotênico & $15.00 \mathrm{mg}$ \\
Cobalina & $100.00 \mathrm{mg}$ \\
Cobre & $16.00 \mathrm{mg}$ \\
Cobalto & $0.40 \mathrm{mg}$ \\
Ferro & $70.00 \mathrm{mg}$ \\
lodo & $1.50 \mathrm{mg}$ \\
Magnésio & $0.14 \mathrm{~g}$ \\
Manganês & $55.00 \mathrm{mg}$ \\
Selênio & $0.20 \mathrm{mg}$ \\
Zinco & $108.00 \mathrm{mg}$ \\
Antioxidante & $100.00 \mathrm{mg}$ \\
Promotor de Crescimento & $100.00 \mathrm{mg}$ \\
\hline
\end{tabular}

Composiçảo Básica do Produto: Carbonato de Cálcio, Farelo de Glúten de Milho-60, Farelo de Soja, Farelo de Trigo, Fosfato Bicálcico, Miljo Integral Moído, Cloreto de Sódio (sal comum), Melaço, Premix Mineral Vitamínico.

Eventuais Substitutivos: Alfafa Desidratada, Aveia (grãos Laminados), Farelo de Algodão, BHT, Bacitracina de Zinco, Farelo de Arroz, Farelo de Girassol, Leveduras, Triguilho, Arroz Quebrado, Etoxiquim, Cevada, Sorgo Integral Moído, Protenose, Polpa Cítrica. 


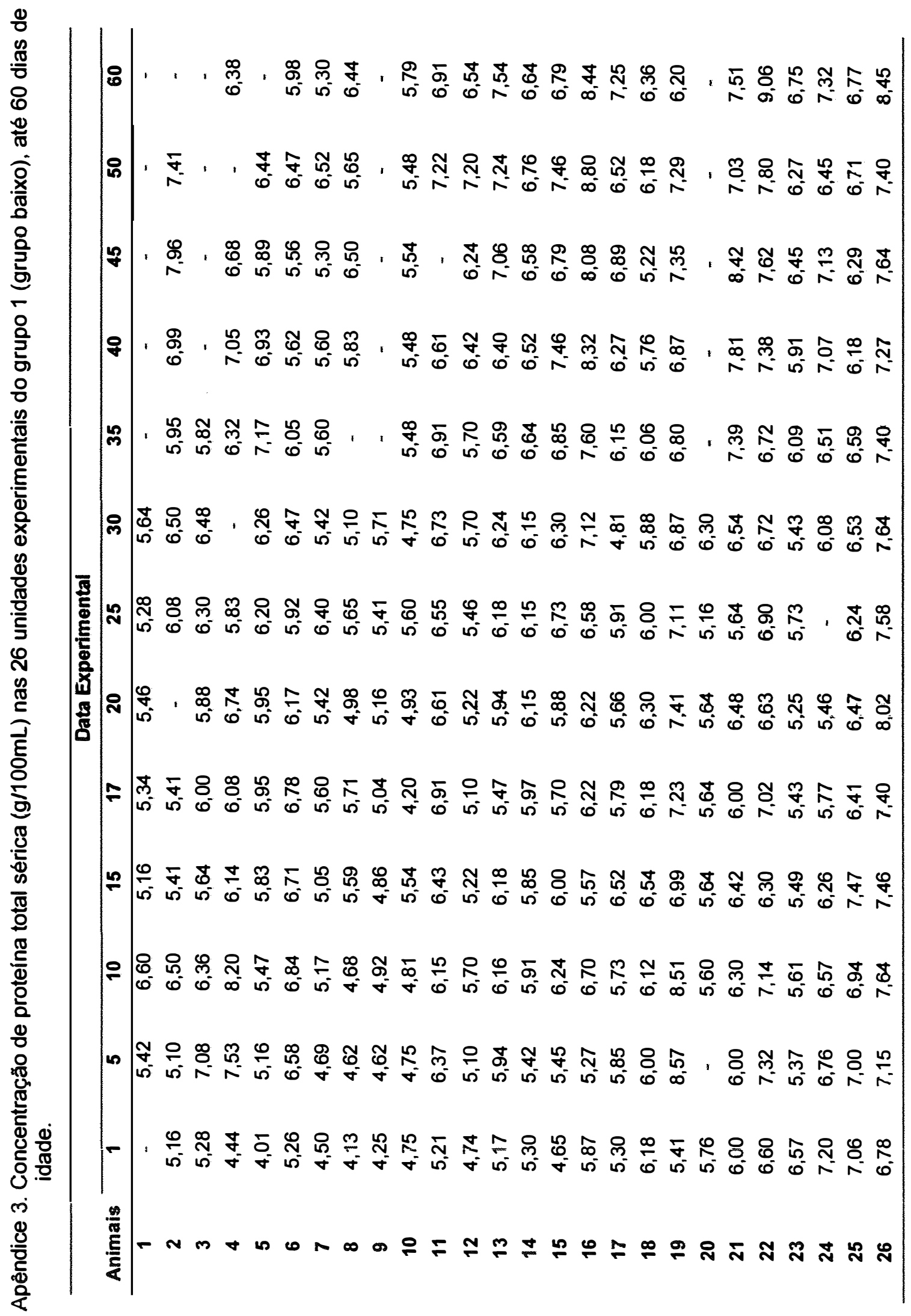




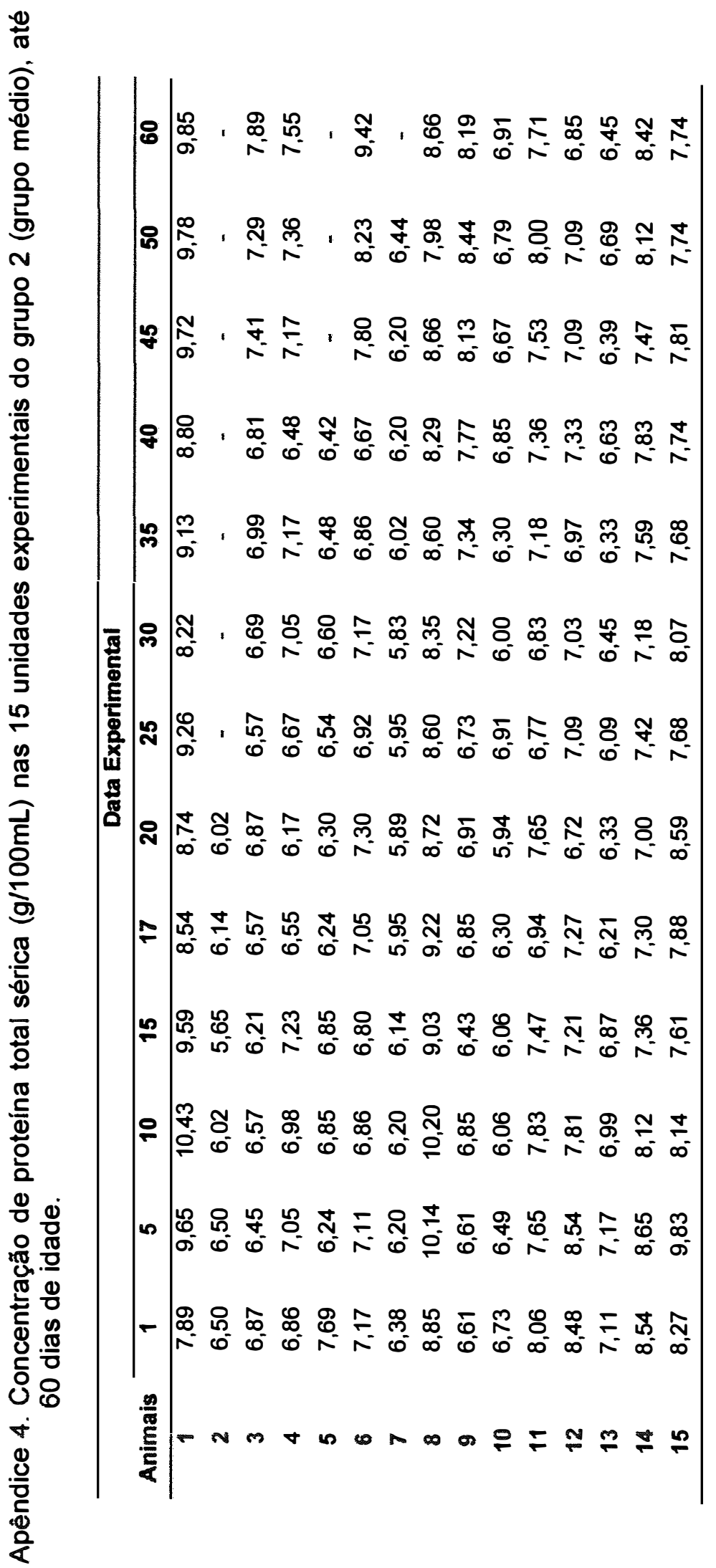




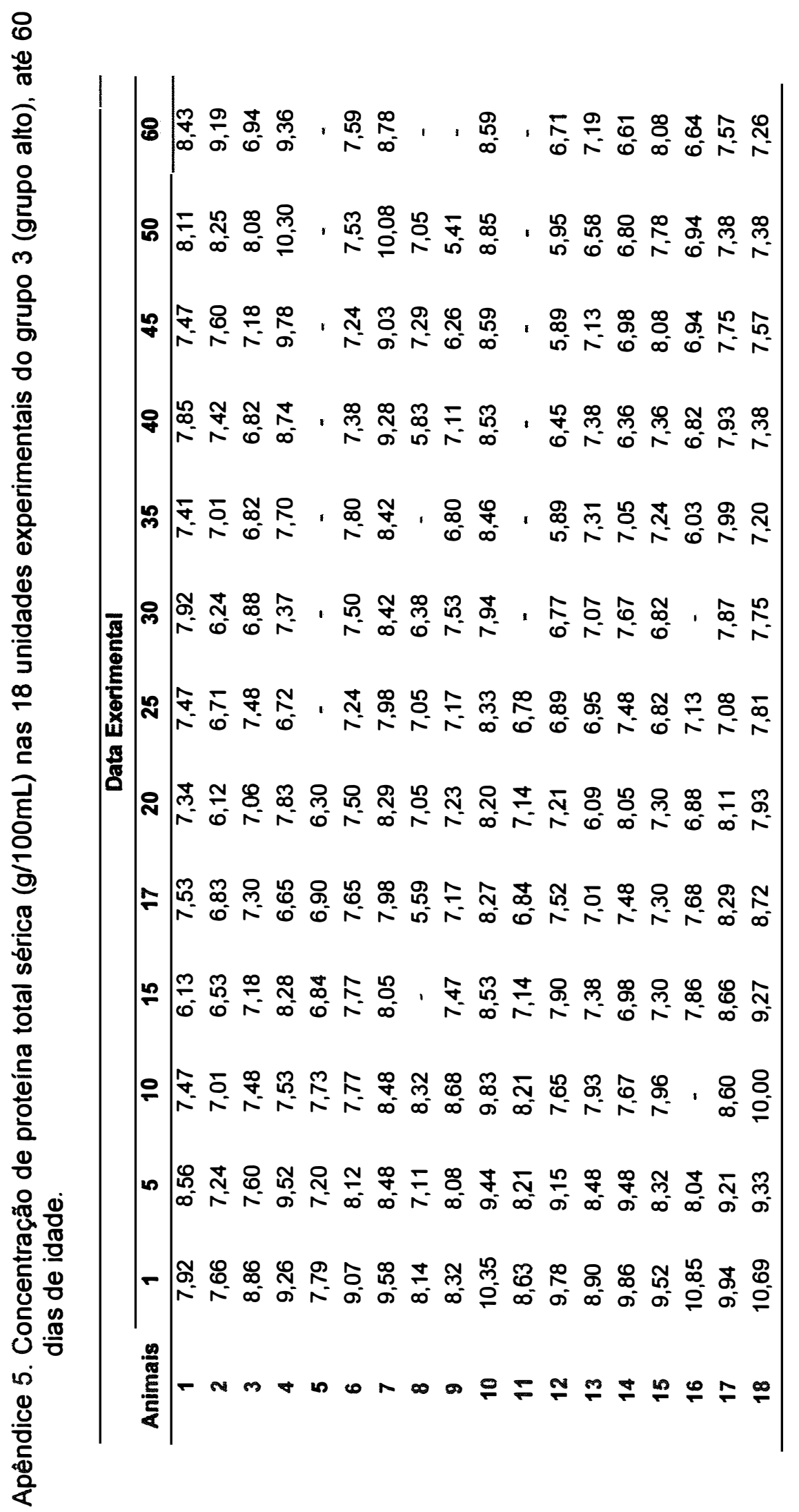




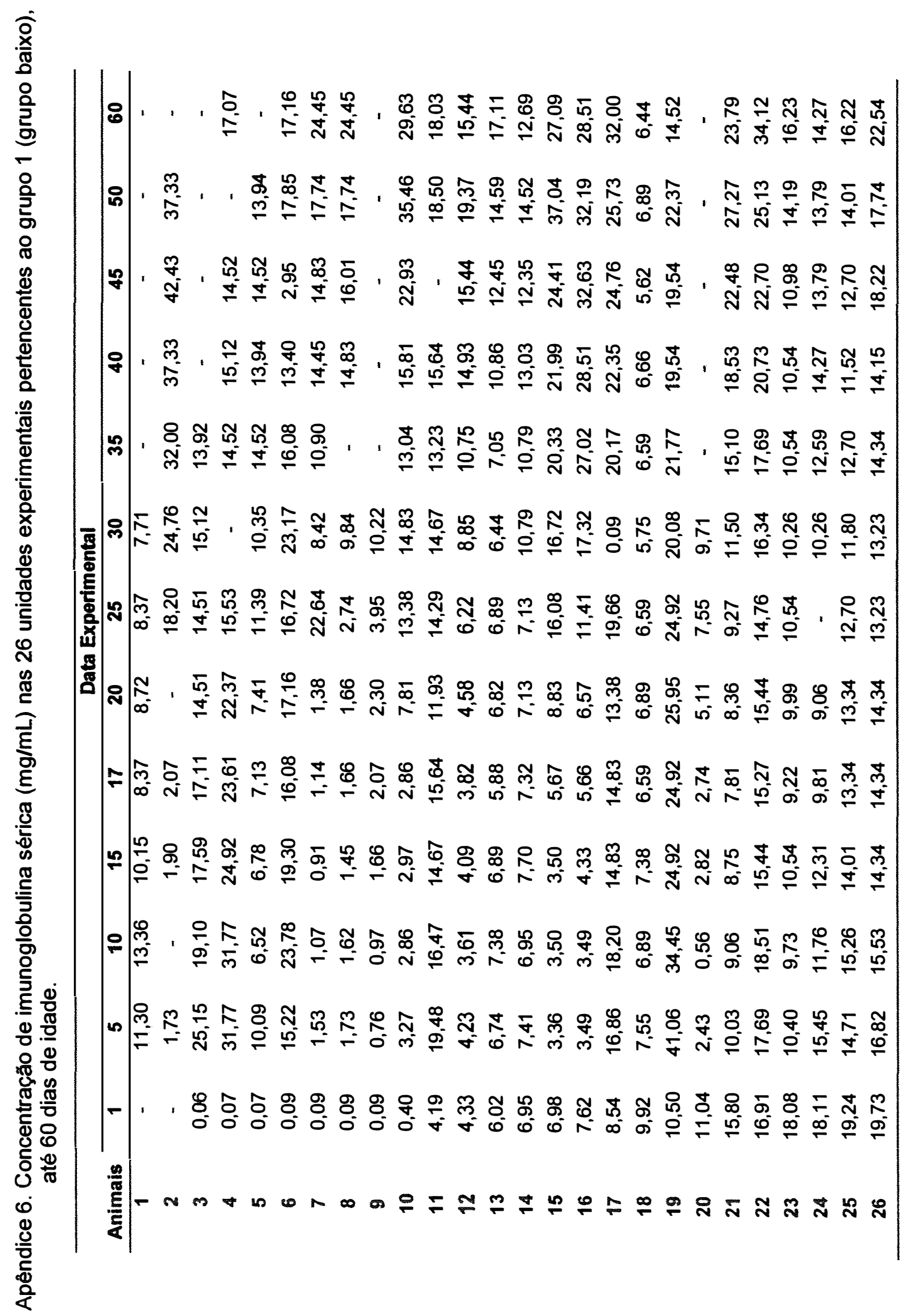




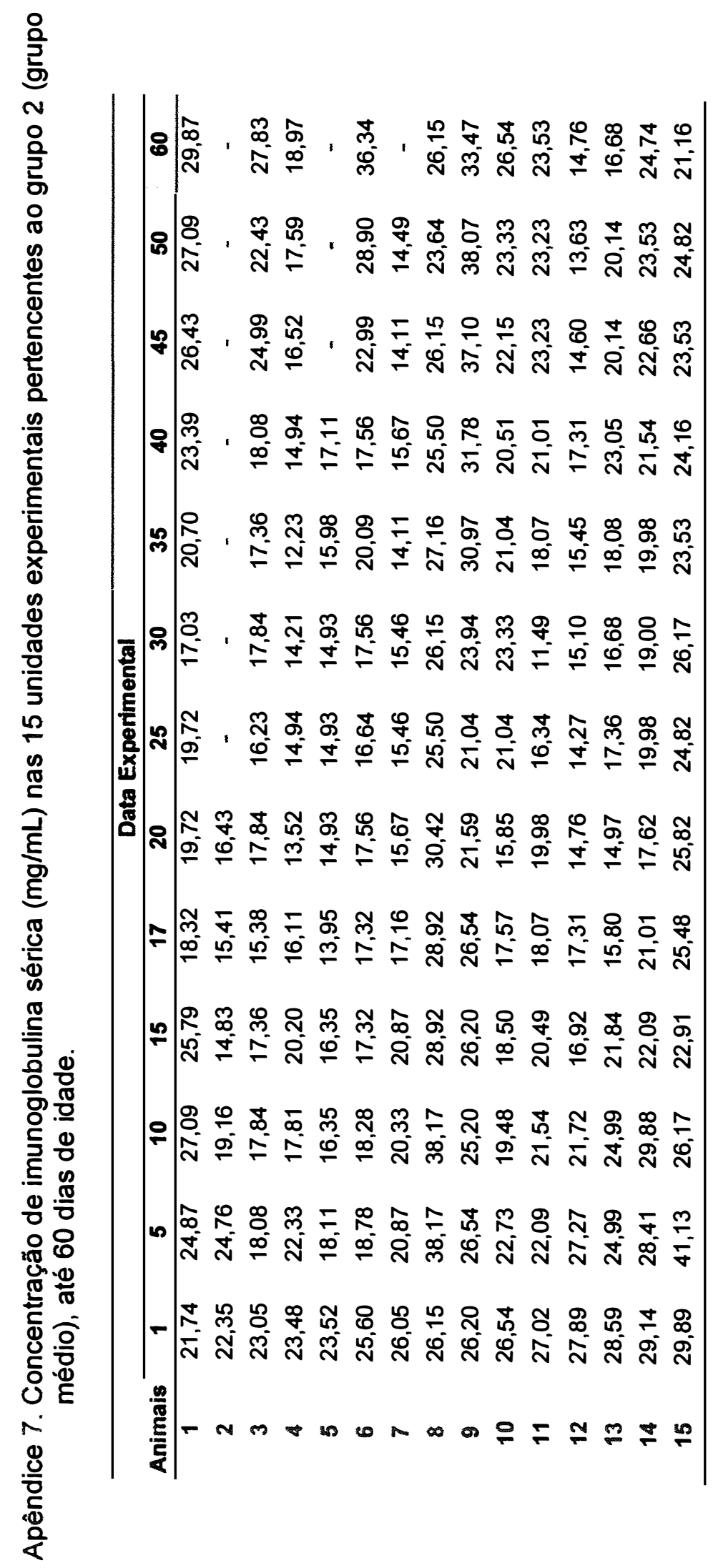




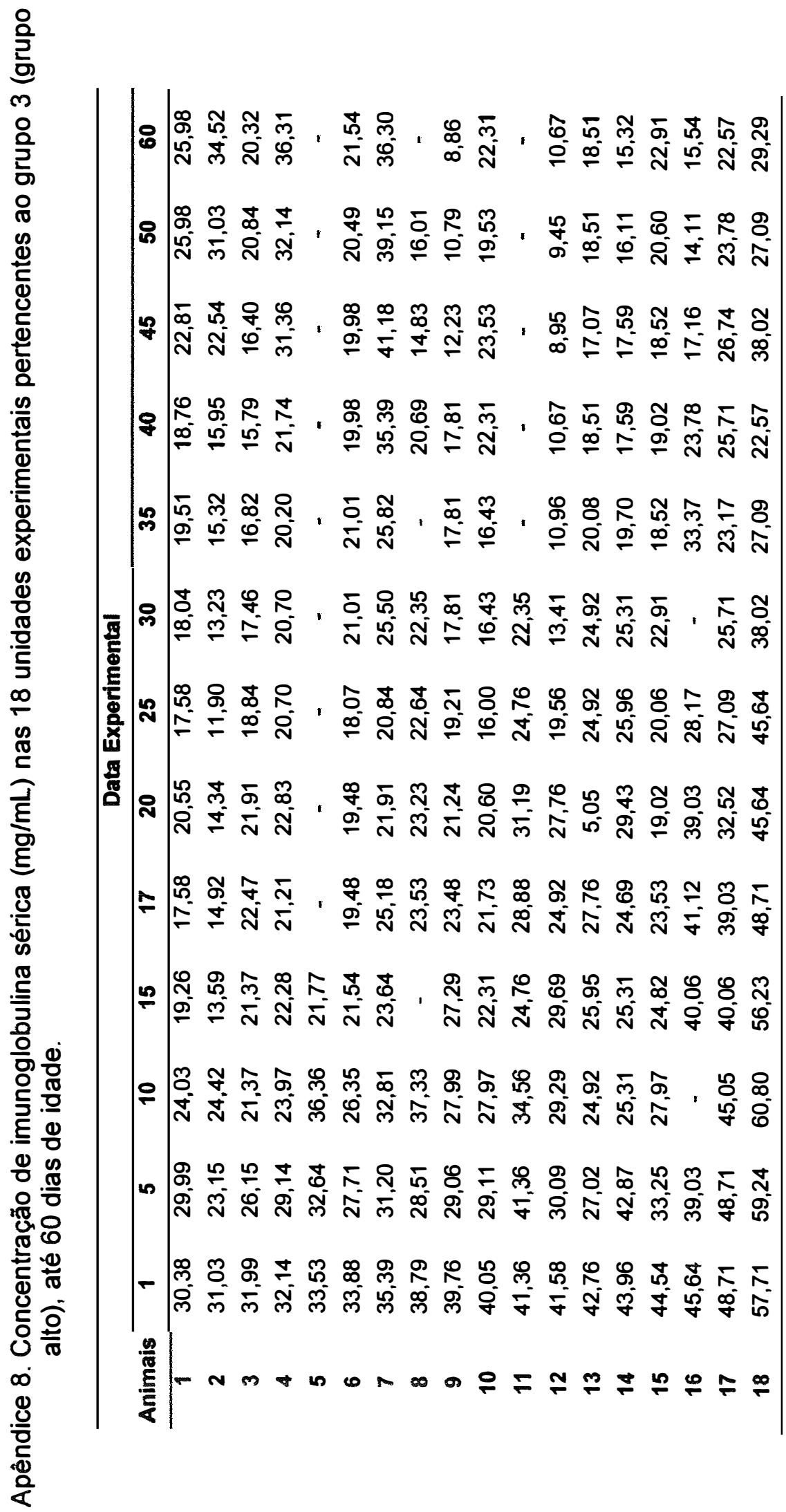




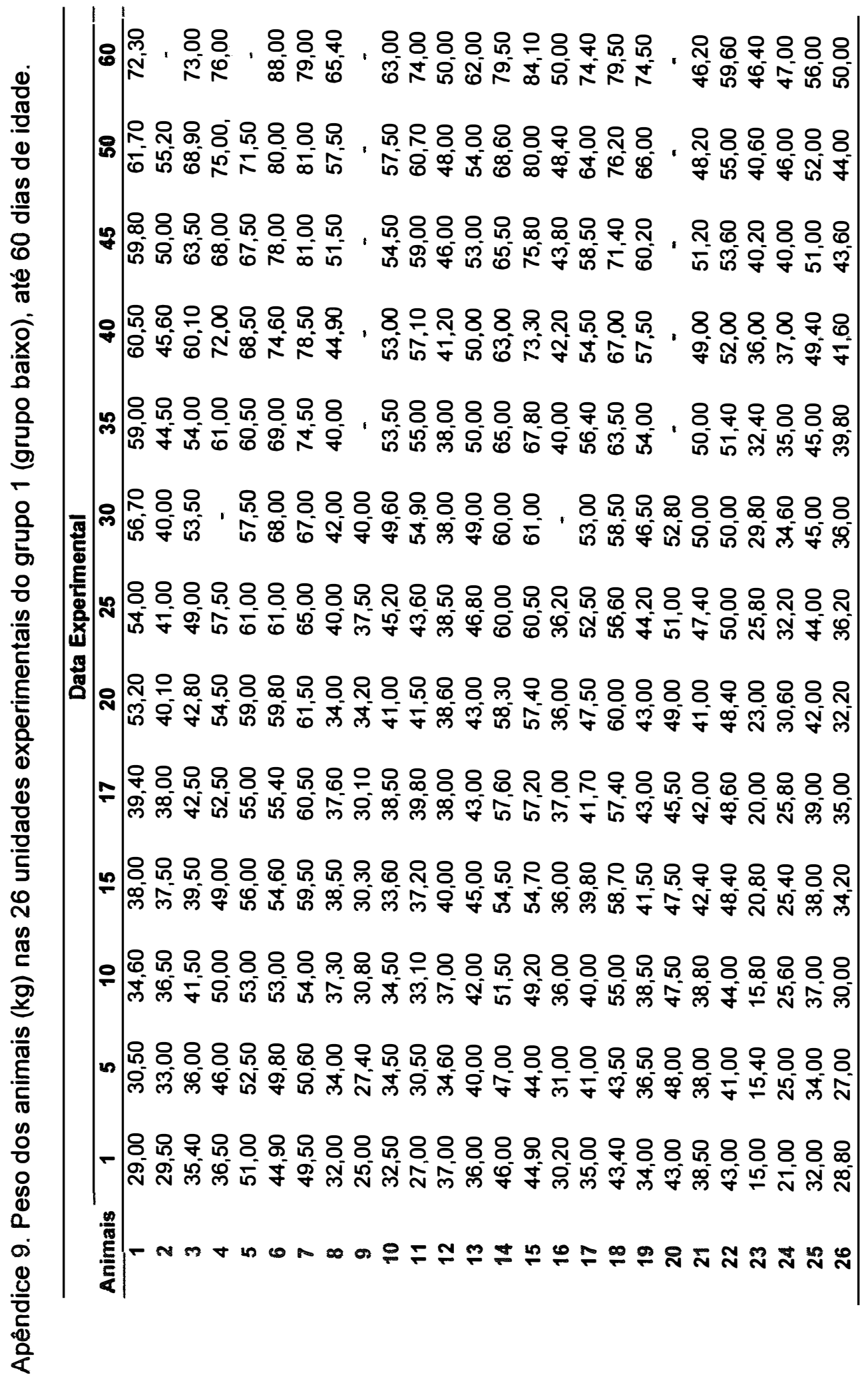




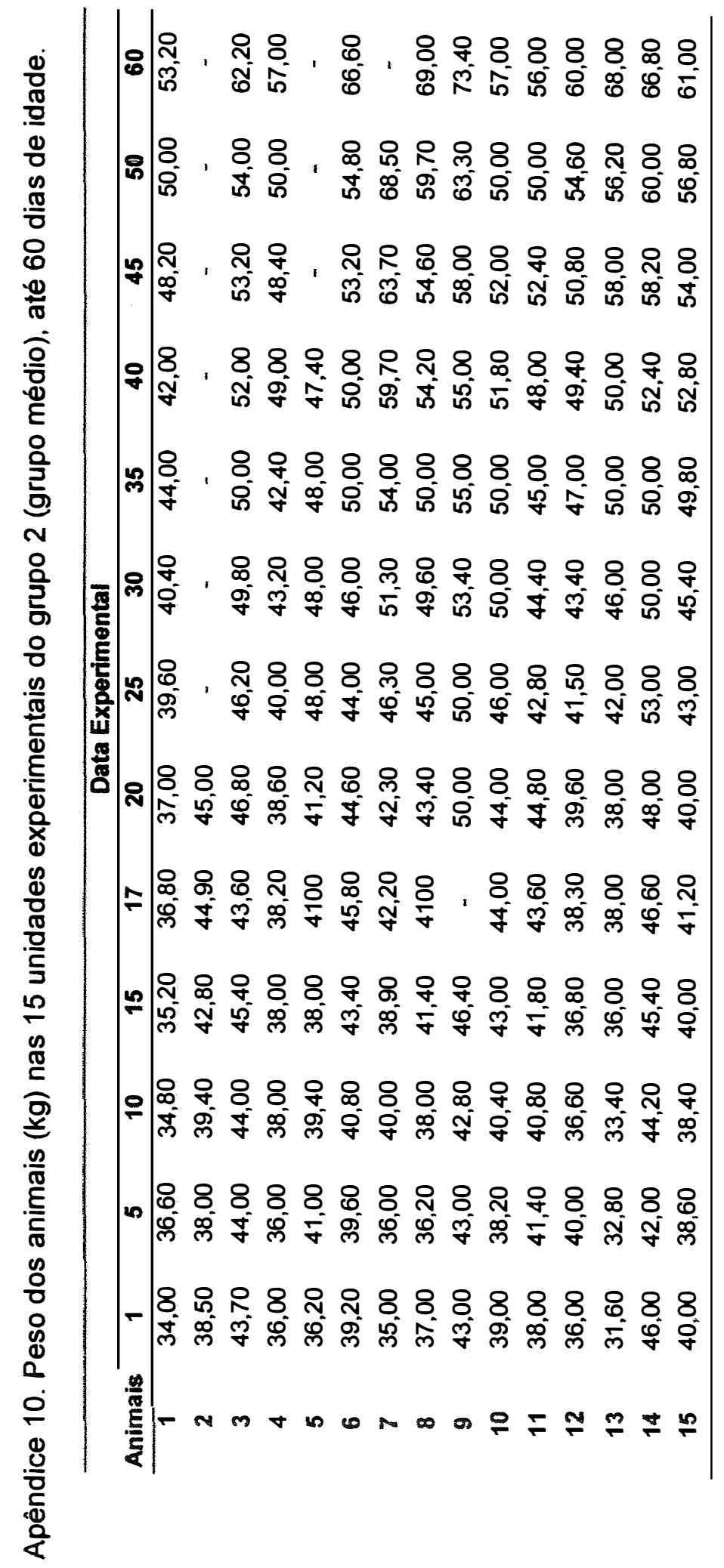




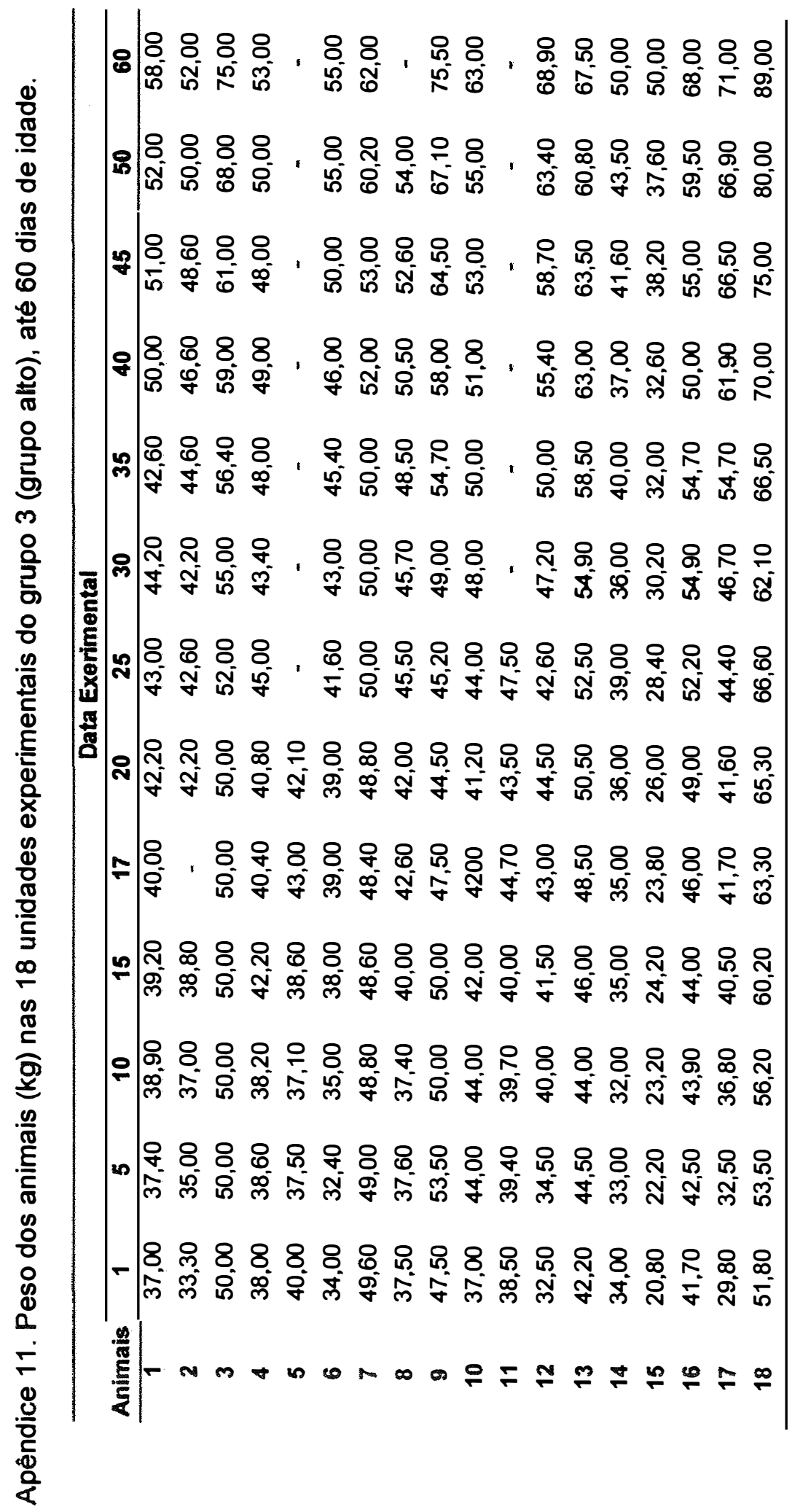




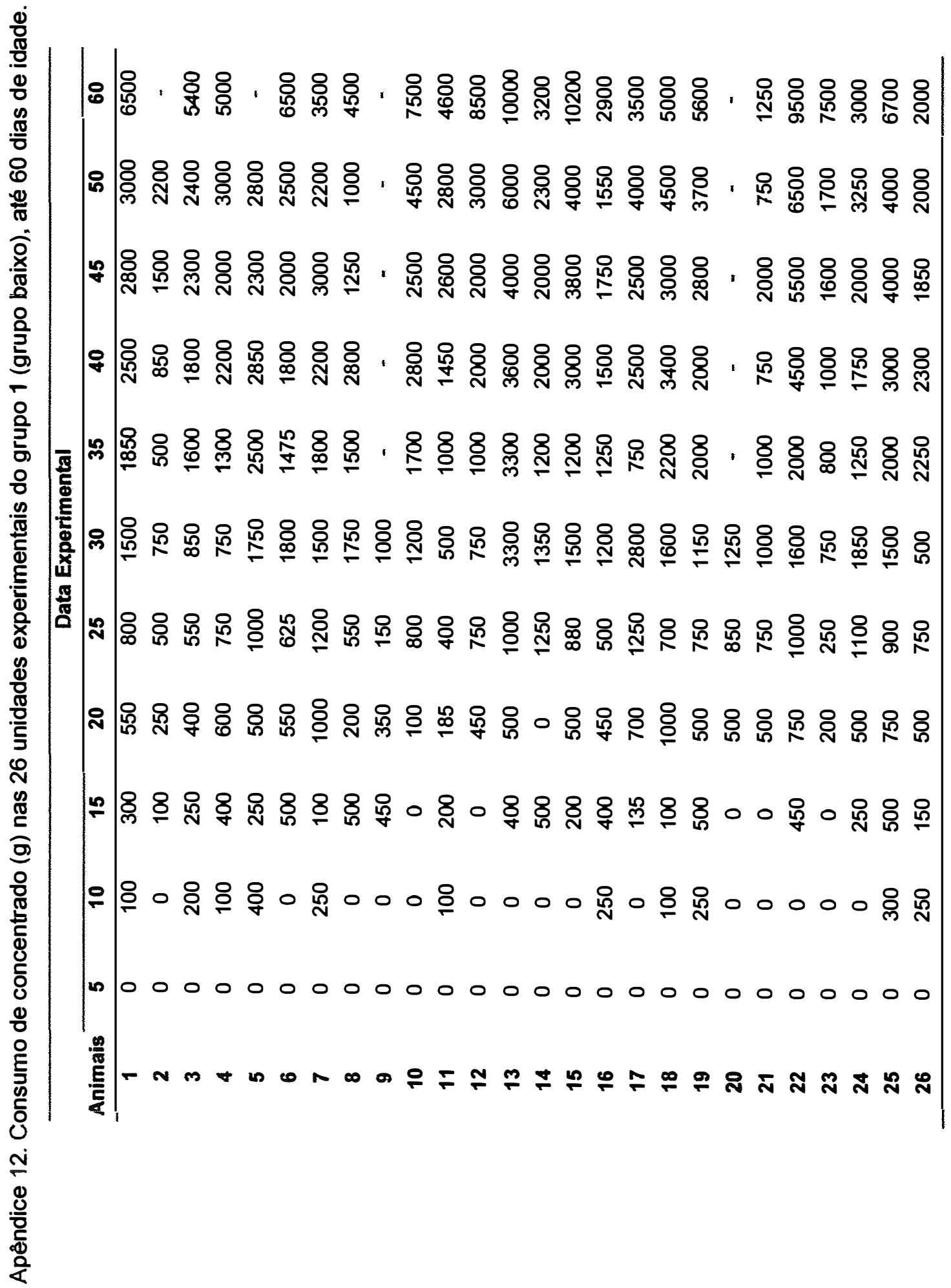




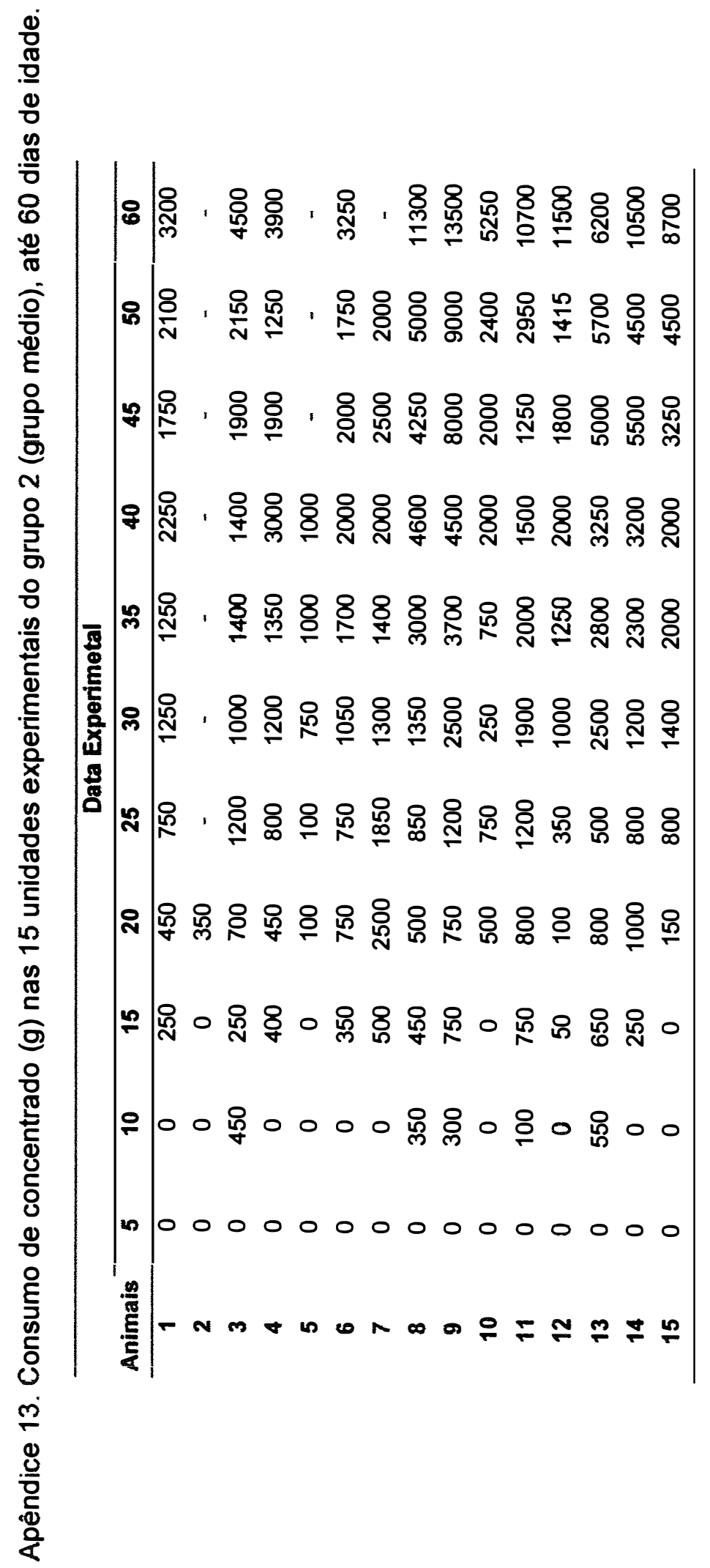




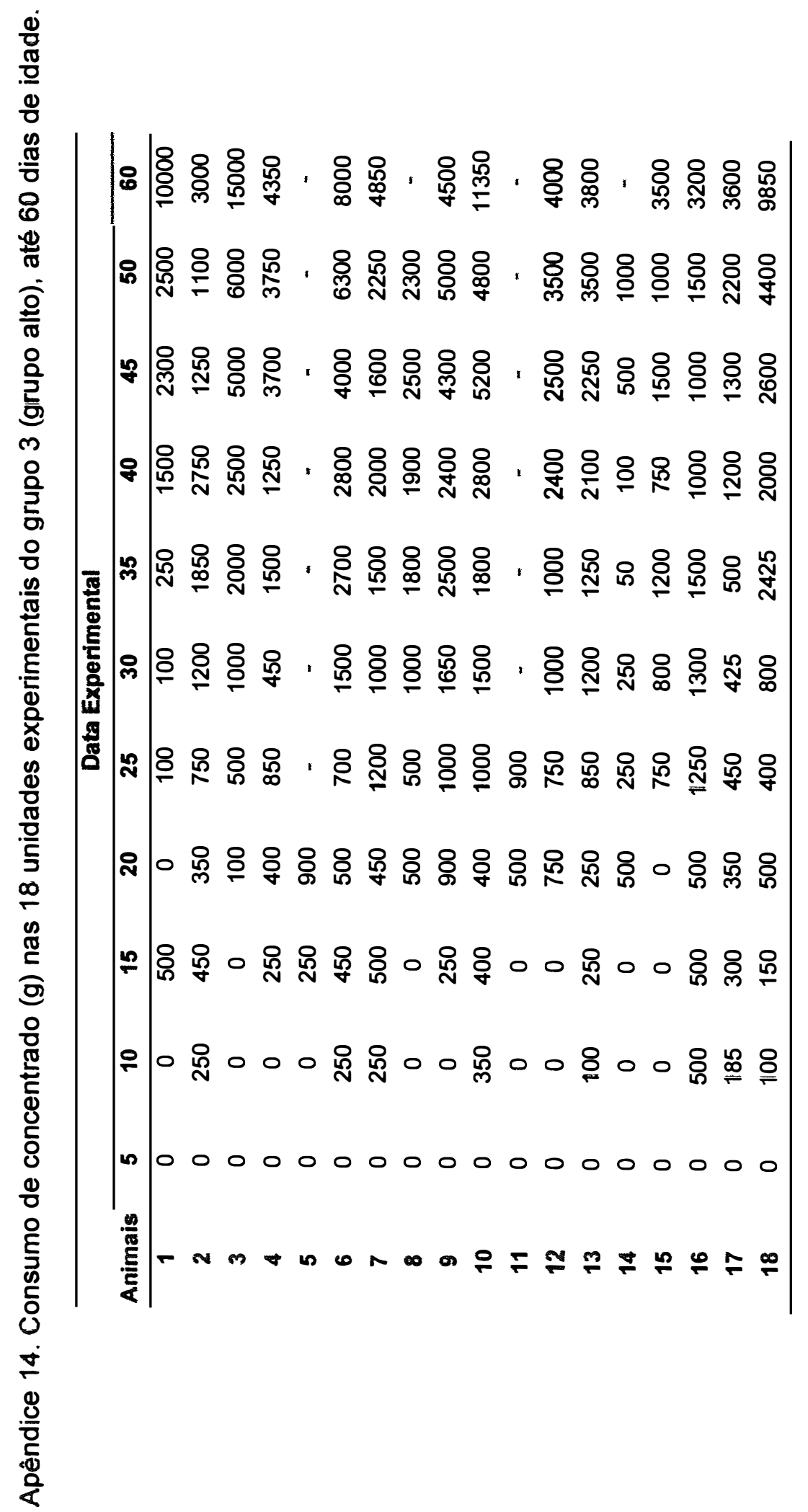




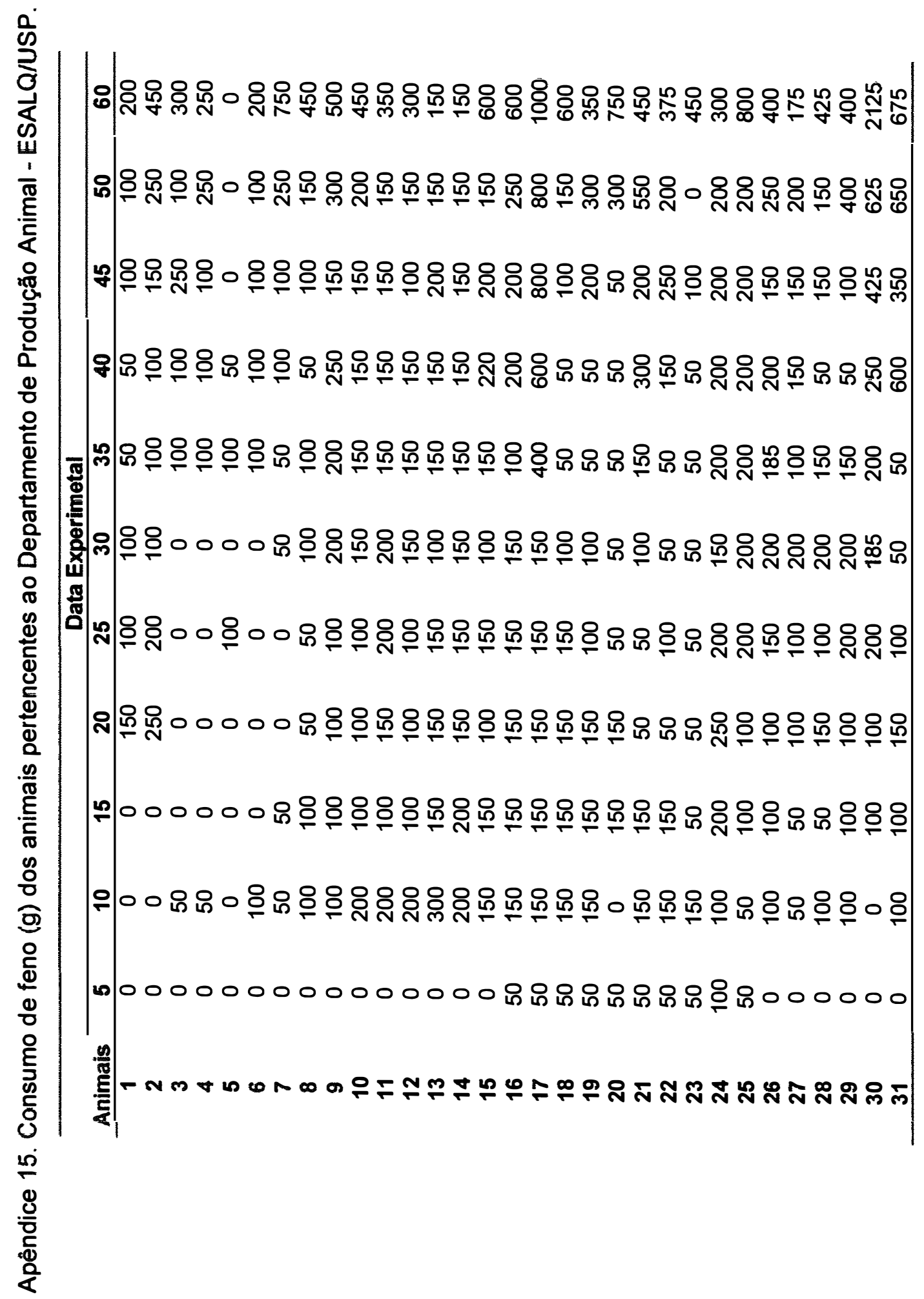


Apêndice 16. Ganho de peso médio total $(\mathrm{kg})$ dos animais nos diferentes grupos experimentais.

\begin{tabular}{|c|c|c|c|}
\hline & Grupo 1 & Grupo 2 & Grupo 3 \\
\hline Animais & Ganho total & Ganho total & Ganho total \\
\hline 1 & 38,3 & 19,2 & 21,0 \\
\hline 2 & -1 & -1 & 18,7 \\
\hline 3 & 37,6 & 18,5 & 25,0 \\
\hline 4 & 39,5 & 21,0 & 15,0 \\
\hline 5 & -1 & -1 & -1 \\
\hline 6 & 43,1 & 27,4 & 21,0 \\
\hline 7 & 29,5 & $-i$ & 12,4 \\
\hline 8 & 33,4 & 32,0 & -1 \\
\hline 9 & -1 & 30,4 & 28,0 \\
\hline 10 & 30,5 & 18,0 & 26,0 \\
\hline 11 & 47,0 & 18,0 & -1 \\
\hline 12 & 13,0 & 24,0 & 36,4 \\
\hline 13 & 26,0 & 36,4 & 25,3 \\
\hline 14 & 33,5 & 20,8 & 16,0 \\
\hline 15 & 39,2 & 21,0 & 29,2 \\
\hline 16 & 19,8 & * & 26,3 \\
\hline 17 & 39,4 & * & 41,2 \\
\hline 18 & 36,1 & * & 37,2 \\
\hline 19 & 40,5 & * & * \\
\hline 20 & -1 & * & * \\
\hline 21 & 7,70 & * & * \\
\hline 22 & 16,6 & * & * \\
\hline 23 & 31,4 & * & * \\
\hline 24 & 26,0 & * & * \\
\hline 25 & 24,0 & * & * \\
\hline 26 & 21,2 & * & * \\
\hline Média & 30,14 & 22,33 & 21,71 \\
\hline $\mathrm{DP}( \pm)$ & 4,26 & 2,14 & 1,87 \\
\hline
\end{tabular}

Grupo 1 nível baixo = até $20 \mathrm{mg} / \mathrm{mL}$ de $\mathrm{lg} \mathrm{G}$

Grupo 2 nível médio = entre 20 e $30 \mathrm{mg} / \mathrm{mL}$ de $\mathrm{lg} G$

Grupo 3 nivel alto $=$ acima de $30 \mathrm{mg} / \mathrm{mL}$ de $\mathrm{lg} G$

DP = Desvio Padrão

${ }^{1}$ Animais com amostras incompletas no total do período experimental foram descartados na análise de ganho total 
Apêndice 17. Probabilidades encontradas na comparação entre os grupos durante o período experimental em relação a concentração média de PT $(\mathrm{g} / 100 \mathrm{~mL})$.

\begin{tabular}{cccc}
\hline Data Experimental & Grupo 1 e Grupo 2 & Grupo 1 e Grupo 3 & Grupo 2 e Grupo 3 \\
\hline 1 & $p<0,0001$ & $p<0,0001$ & $p<0,0001$ \\
5 & $p<0,0001$ & $p<0,0001$ & $p<0,0096$ \\
10 & $p<0,0001$ & $p<0,0001$ & $p<0,0325$ \\
15 & $p<0,0002$ & $p<0,0001$ & $p<0,1350$ \\
17 & $p<0,0002$ & $p<0,0001$ & $p<0,2249$ \\
20 & $p<0,0005$ & $p<0,0001$ & $p<0,3254$ \\
25 & $p<0,0021$ & $p<0,0001$ & $p<0,5601$ \\
30 & $p<0,0044$ & $p<0,0001$ & $p<0,3747$ \\
35 & $p<0,0106$ & $p<0,0051$ & $p<0,8943$ \\
40 & $p<0,0404$ & $p<0,0047$ & $p<0,5363$ \\
45 & $p<0,0113$ & $p<0,0039$ & $p<0,8511$ \\
50 & $p<0,0110$ & $p<0,0059$ & $p<0,9550$ \\
60 & $p<0,0260$ & $p<0,0058$ & $p<0,7046$ \\
\hline
\end{tabular}

Apêndice 18. Probabilidades encontradas na comparação entre os grupos durante o período experimental em relação a concentração média de lgG $(\mathrm{mg} / \mathrm{mL})$.

\begin{tabular}{cccc}
\hline Data Experimental & Grupo 1 e Grupo 2 & Grupo 1 e Grupo 3 & Grupo 2 e Grupo 3 \\
\hline 1 & $p<0,0001$ & $p<0,0001$ & $p<0,0001$ \\
5 & $p<0,0001$ & $p<0,0001$ & $p<0,0007$ \\
10 & $p<0,0001$ & $p<0,0001$ & $p<0,0008$ \\
15 & $p<0,0001$ & $p<0,0001$ & $p<0,0132$ \\
17 & $p<0,0001$ & $p<0,0001$ & $p<0,0039$ \\
20 & $p<0,0005$ & $p<0,0001$ & $p<0,0190$ \\
25 & $p<0,0122$ & $p<0,0001$ & $p<0,1063$ \\
30 & $p<0,0151$ & $p<0,0001$ & $p<0,1779$ \\
35 & $p<0,0382$ & $p<0,0114$ & $p<0,7226$ \\
40 & $p<0,0720$ & $p<0,0720$ & $p<0,9412$ \\
45 & $p<0,0597$ & $p<0,0621$ & $p<0,9065$ \\
50 & $p<0,4860$ & $p<0,7586$ & $p<0,7022$ \\
60 & $p<0,1238$ & $p<0,3161$ & $p<0,5740$ \\
\hline
\end{tabular}


Apêndice 19. Probabilidades encontradas na comparação entre os grupos durante o período experimental em relação ao ganho de peso médio $(\mathrm{kg})$.

\begin{tabular}{cccc}
\hline Data Experimental & Grupo 1 e Grupo 2 & Grupo 1 e Grupo 3 & Grupo 2 e Grupo 3 \\
\hline 5 & $p<0,1133$ & $p<0,3333$ & $p<0,5345$ \\
10 & $p<0,0029$ & $p<0,0067$ & $p<0,7006$ \\
15 & $p<0,4110$ & $p<0,4175$ & $p<0,9590$ \\
20 & $p<0,1343$ & $p<0,0769$ & $p<0,8703$ \\
25 & $p<0,6042$ & $p<0,5629$ & $p<0,9810$ \\
30 & $p<0,7243$ & $p<0,2185$ & $p<0,1589$ \\
35 & $p<0,2626$ & $p<0,9203$ & $p<0,2599$ \\
40 & $p<0,3088$ & $p<0,4006$ & $p<0,8460$ \\
45 & $p<0,5306$ & $p<0,4581$ & $p<0,9497$ \\
50 & $p<0,1350$ & $p<0,6311$ & $p<0,3350$ \\
60 & $p<0,0105$ & $p<0,4486$ & $p<0,0855$ \\
\hline
\end{tabular}

Apêndice 20. Probabilidades encontradas na comparação entre os grupos durante o período experimental em relação ao consumo médio de concentrado $(\mathrm{g})$.

\begin{tabular}{cccc}
\hline Data Experimental & Grupo 1 e Grupo 2 & Grupo 1 e Grupo 3 & Grupo 2 e Grupo 3 \\
\hline 5 & $p<1,0000$ & $p<1,0000$ & $p<1,0000$ \\
10 & $p<0,9421$ & $p<0,9526$ & $p<0,9878$ \\
15 & $p<0,8878$ & $p<0,9586$ & $p<0,8599$ \\
20 & $p<0,6434$ & $p<0,9045$ & $p<0,5929$ \\
25 & $p<0,8520$ & $p<0,8954$ & $p<0,7754$ \\
30 & $p<0,9236$ & $p<0,2765$ & $p<0,3904$ \\
35 & $p<0,4703$ & $p<0,8711$ & $p<0,4198$ \\
40 & $p<0,6099$ & $p<0,2699$ & $p<0,1497$ \\
45 & $p<0,1526$ & $p<0,8802$ & $p<0,2342$ \\
50 & $p<0,4072$ & $p<0,7295$ & $p<0,6416$ \\
60 & $p<0,0001$ & $p<0,0587$ & $p<0,0036$ \\
\hline
\end{tabular}

